'MEN NOT ALLOWED':

THE SOCIAL CONSTRUCTION AND REWARDS OF

THE WORK OF DOMESTIC MAIDS OF KOLKATA

By

\title{
MANALI DUTTA
}

\author{
A thesis submitted to \\ the Faculty of Graduate Studies and Research \\ in partial fulfillment of \\ the requirements for the degree of \\ Master of Arts
}

Department of Geography and Environmental Studies

Carleton University

Ottawa, Ontario

(C) Copyright

April 2006, Manali Dutta 


$\begin{array}{ll}\begin{array}{l}\text { Library and } \\ \text { Archives Canada }\end{array} & \begin{array}{l}\text { Bibliothèque et } \\ \text { Archives Canada }\end{array} \\ \begin{array}{l}\text { Published Heritage } \\ \text { Branch }\end{array} & \begin{array}{l}\text { Direction du } \\ \text { Patrimoine de l'édition }\end{array} \\ \begin{array}{l}\text { 395 Wellington Street } \\ \text { Ottawa ON K1A ON4 } \\ \text { Canada }\end{array} & \begin{array}{l}\text { 395, rue Wellington } \\ \text { Ottawa ON K1A ON4 } \\ \text { Canada }\end{array}\end{array}$

Your file Votre référence ISBN: 978-0-494-16422-8

Our file Notre référence

ISBN: 978-0-494-16422-8

NOTICE:

The author has granted a nonexclusive license allowing Library and Archives Canada to reproduce, publish, archive, preserve, conserve, communicate to the public by telecommunication or on the Internet, loan, distribute and sell theses worldwide, for commercial or noncommercial purposes, in microform, paper, electronic and/or any other formats.

The author retains copyright ownership and moral rights in this thesis. Neither the thesis nor substantial extracts from it may be printed or otherwise reproduced without the author's permission.
AVIS:

L'auteur a accordé une licence non exclusive permettant à la Bibliothèque et Archives Canada de reproduire, publier, archiver, sauvegarder, conserver, transmettre au public par télécommunication ou par l'Internet, prêter, distribuer et vendre des thèses partout dans le monde, à des fins commerciales ou autres, sur support microforme, papier, électronique et/ou autres formats.

L'auteur conserve la propriété du droit d'auteur et des droits moraux qui protège cette thèse. $\mathrm{Ni}$ la thèse ni des extraits substantiels de celle-ci ne doivent être imprimés ou autrement reproduits sans son autorisation.
In compliance with the Canadian

Privacy Act some supporting forms may have been removed from this thesis.

While these forms may be included in the document page count, their removal does not represent any loss of content from the thesis.
Conformément à la loi canadienne sur la protection de la vie privée, quelques formulaires secondaires ont été enlevés de cette thèse.

Bien que ces formulaires aient inclus dans la pagination, il n'y aura aucun contenu manquant. 


\begin{abstract}
The tasks carried out by women captured in the phrase 'women's work' which forms a vital part of the social process of reproduction and is often unpaid, is not innocent in the sense that it is not a straightforward interpretation of the work that women do. There is an underlying denigration involved as they are monetarily invisible and thereby invisible in official discourses. An examination of the influence of this process as it works in the Indian labour market is attempted here through the work situation that domestic maids in Kolkata face where, despite long hours of hard work, they are in one of the most lowly paid and insecure jobs. The lack of state support, a stagnant economy, increasing competition for available jobs, have come to plague the workers in this sector, most of whom are women. Having to cope with the shackles of illiteracy and the lack of mobility, the domestic maids have limited choices open to them. Domestic responsibilities, like housework and childcare, remain undiminished adding to their burden as social norms strongly favour the male members of the household. Under such circumstances covert resistances both at the site of work and at home have become an important expression of dissent of the maids. However more recently there has been a groundswell of organized movement of these workers at the grassroots level.
\end{abstract}




\section{Acknowledgements}

I would like to acknowledge the keen interest and support of my supervisor Dr. Fran

Klodawsky, Associate Professor of Geography and Environmental Studies at Carleton University, Ottawa.

I would like to thank the other members of the faculty especially Dr. Fiona Mackenzie, for their patient answers to my incessant questions.

I would also like to thank Ms. Hazel Anderson, Graduate Administrator, for her help during the various phases of the program.

I would like to thank my mother for encouraging me to explore the world, my father who has been the guiding light in my life and my husband with whom I want to share life's infinite possibilities.

I remain indebted to all my friends and other acquaintances made during my research work.

I was also invigorated by the efforts of my five year old nephew who emulated my research techniques on all and sundry often to devastating and hilarious effect! 


\section{Table of Contents}

Abstract $\quad$ ii

Acknowledgements $\quad$ iii

Table of Contents iv

List of Tables vii

List of Figures viii

List of Maps $\quad$ ix

List of Acronyms $\quad x$

List of Appendices $\quad$ xi

Glossary xii

Chapter 1 Introduction: Marginalizing 'Women's work' 1

$\begin{array}{lll}1.1 & \text { Organization of the thesis } & 7\end{array}$

Chapter 2 Re-examining patriarchy and domestic work in the Indian context 11

$\begin{array}{ll}2.1 & \text { Women in patriarchy } \\ \end{array}$

2.2 The Discourse on Work 15

$\begin{array}{ll}2.3 \text { Women's work under the cloud of globalization } & 19\end{array}$

2.4 Women in the informal sector 23

2.5 From Resistance to Reconstitution 27

Chapter 3 Women's Work: A historically contested issue 31

3.1 Historical stages in the evolution of women's work in India 36

3.1.1 Pre-colonial period 36

$\begin{array}{ll}3.1 .2 \text { Colonial period } & 37\end{array}$

3.1.3 Post Independence period $\quad 42$

3.1.3.1 Effect of the partition on middle class women 45

3.2 Focus on West Bengal 45

3.2.1 Economic recession and women's prospects 46

3.2.2 The state as a mediator for women $\quad 50$

3.3 Conclusion 52 
Chapter 4 Research Methodology:

Developing a suitable methodology and documenting the research process

4.1 Searching for a suitable methodology 53

$\begin{array}{ll}\text { 4.1.1 Positionality } & 57\end{array}$

$\begin{array}{ll}\text { 4.1.2 Subjectivity } & 62\end{array}$

$\begin{array}{ll}\text { 4.1.3 Power in research process } & 65\end{array}$

$\begin{array}{lll}4.2 & \text { The Research Process } & 68\end{array}$

4.2.1 The research location and participant selection $\quad 68$

$\begin{array}{ll}4.2 .2 \text { Semi structured interviews } & 72\end{array}$

$\begin{array}{ll}\text { 4.2.3 Participant observation } & 74\end{array}$

$\begin{array}{ll}\text { 4.2.4 Action oriented research } & 76\end{array}$

$\begin{array}{lll}4.3 & \text { Reflexivity } & 79\end{array}$

Chapter 5 The bridges that separate:

Employers' attitude towards domestic workers $\quad 80$

5.1 The preference for females $\quad 83$

$\begin{array}{ll}\text { 5.1.1 The necessity of engaging maids } & 84\end{array}$

5.1.2 Gadgets and appliances as failed alternatives $\quad 88$

$\begin{array}{ll}5.2 \text { Considerations for recruitment and retention } & 91\end{array}$

5.2.1 Performance standards driven by the nostalgia for the past 91

5.2.2 The importance of caste and/or religion 94

$\begin{array}{ll}5.3 \text { The maid as the 'other' } & 99\end{array}$

$\begin{array}{ll}5.4 \text { Conclusion } & 101\end{array}$

$\begin{array}{lll}\text { Chapter } 6 \text { Working conditions of the maid: } & 102\end{array}$

$\begin{array}{lll}6.1 \text { A contested terrain } & 105\end{array}$

$\begin{array}{ll}\text { 6.1.1 Deconstructing the male breadwinner } & 106\end{array}$

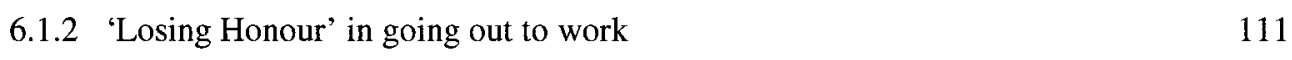

$\begin{array}{lll}6.2 & \text { The travails of work } & 117\end{array}$

$\begin{array}{ll}\text { 6.2.1 Experiences of commuting } & 117\end{array}$

$\begin{array}{lll}\text { 6.2.2 Struggles at the site of work } & 122\end{array}$

6.2.2.1 Extra work: The 'choice' of saying no 125

$\begin{array}{ll}\text { 6.2.2.2 Wages of subsistence } & 127\end{array}$

6.2.2.3 The politics of taking leave 128

6.2.2.4 The disappearance of other benefits 131

$\begin{array}{lll}6.3 & \text { Prisoners of 'choice' } & 133\end{array}$

6.3.1 The prospect of alternate employment 133 
6.3.2 The meaning of being a domestic worker 136

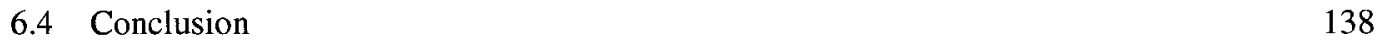

Chapter 7 The 'Unconventional' family: Women's struggle within the family structure.

7.1 When neglect becomes routine 144

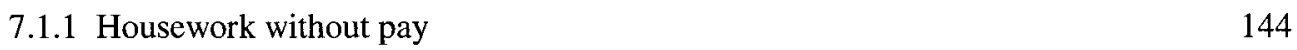

$\begin{array}{ll}\text { 7.1.2 Childcare provisions } & 147\end{array}$

$\begin{array}{lll}7.2 & \text { Daughter and mother } & 152\end{array}$

$\begin{array}{lll}7.3 & \text { The politics of control } & 160\end{array}$

$\begin{array}{llr}7.4 & \text { Conclusion } & 166\end{array}$

Chapter 8 In Drawing A Conclusion:

Struggle, Resistance and Reconstitution.

168

$\begin{array}{lll}8.1 & \text { Empowerment through organizations } & 169\end{array}$

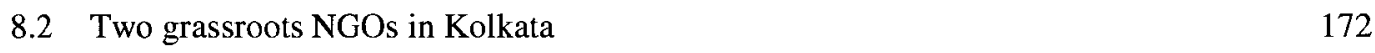

$\begin{array}{ll}\text { 8.2.1 Parichiti } & 174\end{array}$

$\begin{array}{ll}\text { 8.2.2 Nishtha } & 180\end{array}$

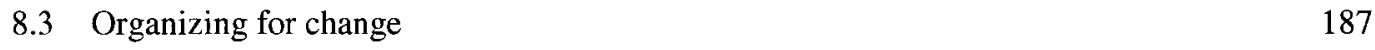

$\begin{array}{ll}\text { 8.3.1 Building on the alternatives } & 187\end{array}$

$\begin{array}{ll}\text { 8.3.2 Strategies and Issues } & 188\end{array}$

8.4 'Pulama' - A case study 195

8.4.1 - A studied case of continued abuse $\quad 195$

$\begin{array}{ll}8.4 .2 \text { - The realizations for Parichiti } & 200\end{array}$

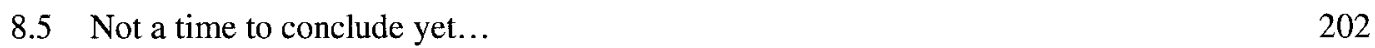

$\begin{array}{lr}\text { Appendix } & 205\end{array}$

$\begin{array}{lr}\text { Bibliography } & 212\end{array}$ 


\section{List of Tables}

Table 2.1 Worker Population Ratio by Sex (Census and NSS survey), 1971-94 17

Table 2.2 Impact of SAP on poor women's living conditions in India 22

Table 3.1 Statewise selected Industrial characteristics of India (2000-01) 47 


\section{List of Figures}

6.1 Typical workday and wage rates for two different women in paid work 103 


\section{List of Maps}

Map 3.1 Political map of India 33

$\begin{array}{lll}\text { Map } 3.2 \quad \text { District Map of West Bengal } & 34\end{array}$

$\begin{array}{lll}\text { Map 4.1 Research Area Location: Calcutta } & 70\end{array}$

Map 4.2 Research Area Location: South 24 Parganas 71 


\section{List of Acronyms}

BRAC Bangladesh Rural Advancement Committee

CDF Cooperative Development Foundation

CITU Center for Industrial Trade Unions

CPI(M) Communist Party Of India (Marxist)

DGE\&T Directorate General of Employment and Training

HRLN Human Rights Law Network

ILO International Labour Organization

IMF International Monetary Fund

MEPZ Madras Export Processing Zone

NCW National Commission for Women

NDWM National Domestic Worker's Movement

NEP New Economic Policy

NGO Non Governmental Organization

NSSO National Sample Survey Organization

PAR Participatory Action Research

PBGMS Paschim Banga Ganatantrik Mahily Samity

(The United Democratic Bengali Women's Organization)

PDS Public Distribution System

SAP Structural Adjustment Program

SEWA Self Employed Women's Association

SNA System of National Accounts

WTO World Trade Organization

WWF Working Women's Forum 


\section{List of Appendices}

Appendix A Snapshot of working lives of the maids 205

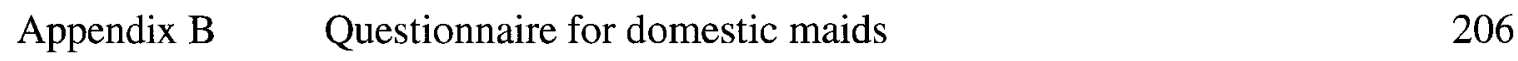

Appendix C Report of my days spent at Parichiti $\quad 208$ 


\section{Glossary}

\begin{tabular}{|c|c|}
\hline ayah & Female general helping hand employed in the household \\
\hline balak balika bahini & Group of child volunteers \\
\hline Banga bhanga & The partition of the state of Bengal in British India. \\
\hline bhadra kaj & Respectable profession, which does not include much physical rigours \\
\hline bhadralok & Middle class male, cultured and educated \\
\hline bhadramahila & Middle class female, cultured and educated \\
\hline bhalo biye & Good marriage \\
\hline boka & Foolish \\
\hline chalaki & Cunning intelligence \\
\hline Chetona & Realization \\
\hline chikon & Fine embroidery work \\
\hline dan & Gift \\
\hline$i z z a t$ & Family and personal honour \\
\hline kishori kishore bahini & Group of adolescent volunteers \\
\hline kshatriya & Martial caste, second highest status in Hindu caste hierarchy \\
\hline lajja & Shame and modesty \\
\hline mahila mandal & Local women's association \\
\hline mahila samity & Organizational unit of local women \\
\hline mai & Part-time female domestic worker (term used in Northern India) \\
\hline mazdoor & Industrial workers \\
\hline muree & Puffed rice \\
\hline Nishtha & Dedication \\
\hline panchayat & Local governing body at the village level \\
\hline Parichiti & Identity \\
\hline puja & Hindu ritual of worship involving offering of food \\
\hline purdah & Seclusion of women \\
\hline ruti & Indian home-made bread \\
\hline Shramshakti & Labour power \\
\hline
\end{tabular}




\section{Chapter-1}

\section{Introduction: Marginalizing 'women's work'}

'MEN NOT ALLOWED' - is an eye-catching warning inscribed in green over a yellow background on one particular compartment in every local train that plies between the city of Kolkata and its suburbs. One can find domestic maids, huddled in scores, in these compartments on their way to work and back. These 'ladies compartments' have been assigned by the railway authorities to allow women an exclusive space to travel in, while the rest of the compartments (deemed as 'general' compartments) of the train, usually eight to nine in number, can be used by either sex. On many occasions when I have traveled in these trains I was struck by the fact that male passengers often admonished their female counterparts who had strayed out from the ladies compartment to the general compartments. I have also overheard many female white-collar officegoers offering similar advice to the maids, their 'sisters' and co-passengers, but denizens of the lower class.

'Men not allowed' is an apt metaphor for the conditions in Indian society that have failed to tear down the barriers, the most potent of which are poverty and patriarchy, which divide its population even today. Economic wealth divides the population into the 'rich' and the 'poor'. While the poor includes both men and women, the position of women is much more vulnerable. They not only suffer from material impoverishment but are also prevented by social dictates from adopting any effective means to break out of their poverty, unlike their male counterparts. Widespread illiteracy, lack of mobility, and the violence committed against them, affect their daily lives profoundly. By singling out women as an exploited category among others, attention is being drawn to the fact that 
despite some women holding positions of power in society and some men being counted amongst the suppressed, a woman's position has been found to be much more vulnerable than a man's when a particular level in the socio-economic hierarchy is considered (Elson 1995:2). Poor women remain restricted to the bottom rung of a multitude of hierarchies. This is an exclusive, unique space of exploitation and impoverishment from which even poor men are exempt.

Women's secondary position in the Indian society vis-à-vis men is reflected in their weak claims/performances in every set of indices such as literacy rates, incomes earned, access to resources and health care (Narasimhan 2000:221). These women are deeply embedded in an exploitative context which offers only further drudgery and poverty and embraces them so tightly that escape from this predicament is near impossible. As the poorest among the poor and the weakest among the weak, they remain invisible in census studies or other statistical records and thereby remain unidentified as possible participants in the development process.

A question that can justifiably arise at this point is how much does outside paid employment affect a woman's position in family and society? To answer such a question, there is need to get rid of a straightforward assumption that employment creates economic independence among women and thereby leads to an improvement in their familial and social status. This notion neglects the work conditions and the economic and social security that are enjoyed by the workers, which need to be examined critically in order to understand the benefits that workers derive from selling their labour. Such assumptions have also been built by neglecting the fact that labour, unlike land, needs to be produced and this production requires the pledging of time and effort which has 
overwhelmingly been provided by women as unremunerated labour across the world (Elson 1995:10). This has been irrespective of the outside employment responsibilities for some although certain differences exist between them on the basis of class lines as the more well-to-do hire outside help to take care of the job on their behalf. For poorer women who have no option to hire others, outside employment has led to a 'double burden' that puts further pressure on their time and abilities (ibid), even though it may have eased the financial strain to some extent.

This is also an argument against the false consciousness in macroeconomics of the household as a united welfare maximization unit. The overwhelming influence of patriarchy contributes to the exploitation of poor women within their families. As Sen (1992:122-3) points out, within households the inequalities that exist among members of different sexes can be seen in the division of labour and resources used by them, such as the amount of care and education provided or privileges and freedoms enjoyed. The disparities apparent in nutrition and health standards among family members indicate the prejudice against women in India (Narasimhan 2000:221). Case studies have also exposed that while male social and personal expenditure maintains its constancy in the face of increasing economic hardship, women's response is to invest more of their labour in an effort to compensate for losses within and outside the household (Sadasivam 1997).

In this research I hope to address some of the concerns in regard to the working and living conditions of the domestic maids of Kolkata. Here I aim to examine the role of the state, community and the household in creating and sustaining the devaluation of 'women's work', in a society that incriminates both the work and the worker. The research conducted here aims to reveal the understated importance of this work and 
provide a platform for progressive action to recognize it as a valuable social and economic contribution of women.

Kolkata (Calcutta) ${ }^{1}$ is the capital city of West Bengal, a state in eastern India, which was once the leading industrialized state, but is now ranked eleventh among twenty five states of India (Roy 2003:89). With $2.7 \%$ of India's area $(88,752 \mathrm{sq} \mathrm{km}$ ) and about $7.8 \%$ of the country's population this state is the most densely populated with 904 persons/sq $\mathrm{km}$ as per the 2001 census (Government of West Bengal 2004:4). It has become the destination for streams of mobile people searching for livelihood and shelter in the capital city. Gendered research on poverty in this area has revealed a complex intertwining of factors (Roy 2003:18). As an extension of this debate I would like to focus on the gendered differentiation of the labour market and its manifestation at the level of the household. In particular I am interested in finding out how paid domestic work (as 'women's work') has come to be constructed in this context.

Kolkata has a lot in common with India's other metropolitan centers. One commonality is that its rich, upper middle and middle classes depend to a large extent on the cheap labour provided by workers migrating from rural areas. The preference for females in such jobs is widespread. This is due to the patriarchal nature of Indian society wherein women are considered to be more submissive, obedient, trustworthy, vulnerable and proficient in such jobs as compared to men. Hence they can be manipulated easily and can also be exploited and paid lower wages as compared to their male counterparts. The limited choice for alternate sources of income that women face in a depressed economy such as Kolkata, compels them to take up low paid jobs like domestic service.

\footnotetext{
${ }^{1}$ Calcutta was renamed as Kolkata on January 1, 2001 when the proposal was passed by the state government of West Bengal. The British East India Company had given the name Calcutta to the city when it laid the foundation of the city in 1690 based on a preexisting rural settlement in the area called Kalikata.
} 
To investigate the lives of domestic workers in India, I have carried out my research within the specific context of the work of the 'part-time' domestic maids of Kolkata. These maids commute daily from their homes (in the peri-urban areas) to the city and work for long hours for middle class households, serving several households (each of which they visit for a few hours) during the day. Thus, although working for a few hours in each house, their work day can stretch to ten or twelve hours. Coming from poverty stricken families and with few recognized skills, these lower class women, despite their hard labour, are faced with a paradoxical situation that I want to grapple with in this thesis. The question involved here is, do the activities involved in paid domestic work, carried out by the maids in Kolkata, and the value assigned to that work, keep them in poverty? Studying the gendered aspects of this occupation and those who are engaged in it, I hope, will provide an insight into debates that revolve around the growing trend of 'feminization of poverty' (Moghadam 1999, Roy 2003).

The dichotomy that prevails in urban India, whereby the smooth functioning of middle and higher class households is achieved through the labour of poorly paid domestic workers has prompted me to examine the conditions that favour the appropriation of the labour of poor women at cheap rates. I argue that this exploitation has been perpetuated at a multitude of scales ranging from the official statistics at the international and national level to that of the local society and politics to that of the 
household. The Census ${ }^{1}$ of India and the $\mathrm{NSSO}^{2}$ (National Sample Survey Organization) have used income generation to define work. When work comes to be defined in official discourses only on the basis of its economic value, it excludes large number of women whose work inside or outside the home meet the consumption needs of the family, but does not involve any monetary payment. Devaluing such work has permeated the labour market where I argue that the work done by women is characterized as 'light', 'part-time' and 'unskilled' and consequently low paid. The domestic maids of Kolkata, despite working for long hours in a number of houses doing the most laborious tasks, remain entrapped in those sections of the labour market that offers no security, no rights and minimal pay. A stagnant economy, an unsympathetic government and pressures to conform to the global dictates of disappearing welfare and increased competitiveness have contributed to exacerbating the plight of these workers.

The middle class accrues the benefits of their labour. Here I argue that women of the middle class are as much responsible for perpetuating the exploitation of the labour of poor women as their male peers. The 'unity of gender' does not override class barriers. Women are not found to be 'innocent bystanders' but actual perpetrators of abuse of their 'sisters'. They too remain complicit in sustaining the myth of women's work as something which is complementary, less relevant and therefore less worthy of attention or reward.

This however does not mean that the adversities faced by these women have been passively accepted by them as a given. The common portrayal of passive victimized

\footnotetext{
1 The Census of India is the primary source of information about the demographic characteristics of the population of India. The census is carried out by the office of the Registrar General and Census Commissioner, India, Delhi (Verma 1988)

${ }^{2}$ The government of India had set up an organization called the National Sample Survey (NSS) in 1950 for conducting large scale surveys on a periodic basis. In 1972 this was renamed as National Sample Survey Organization or NSSO (UN, ESCAP, 2003).
} 
women found in development literature stands repudiated on closer examination as I also argue that every attempt is made on their part to strategize, adapt, resist and attempt to transform the situations at their workplace, within their family settings and in the wider society. In the past these attempts remained largely confined to the individual or local scale, but now they are gradually growing into larger collective movements.

As the negative impacts of 'trickle down' development whose failure to reach the weaker sections become more and more apparent, the legitimacy of this form of development is being challenged. Instead 'grassroots globalization' or 'globalization from below' has started to replace it both at the local popular level as well as within critical academic debate. Appadurai (2001a:3) characterizes this development as 'autonomous' and 'democratic' in the sense of it being opposed to dependency on corporate capital and the nation-state system. He has called for academic research to direct its searching gaze to these newer developments as a useful device to honour its commitment "to the 80 percent of the population of the world (now totaling 6 billion) who are socially and fiscally at risk" (ibid). This has also been a primary inspiration of my research as I argue that grassroots NGOs can play a significant role in bringing about greater equity, freedom and redistribution among the population in both the materialistic and ideological spheres of action.

\subsection{The organization of the Thesis}

There are a total of eight chapters in this thesis. In the first three chapters I make an attempt to present the theoretical and contextual background. The second chapter is a continuation of the first in its search of links to explain the social construction of 
'women's work' as a denigration of the activity and the women who are employed in it. Since my purpose has been to search for reasons to explain the low wage rates received by the domestic maids of Kolkata, my search has led me to the roots of the issue which has been the partial and inadequate enumeration of work performed by women in official discourses. I have also looked at the broad social and economic structures of development, globalization and patriarchy and the specific promises and problems that they hold for poor women in the economic south. The implementation of the SAP (Structural Adjustment Programs as promulgated by the World Bank and other global financial bodies) has further eroded poor women's claims to an adequate share of resources.

In the third chapter I have attempted to narrow the scale from the global to the national and regional to understand the position of the women worker in the local context. I have therefore provided an overview of the historical and contemporary forces at work in India, emphasizing the conditions in West Bengal (the state which forms the specific context of this research) which have had their influence in developing women's position as workers and providers of their families. I have traced the links forward from the Nationalist Movement which arose in India to resist colonial powers and its symbolic extension to the domestic and public roles that were adopted in the life styles of the middle class of the nation, especially in relation to women. Subsequent developments like independence and partition of the country had their impacts on women's participation in the work force. In contemporary times, in West Bengal, the sluggish growth of industry and inadequate agricultural reforms indicate the failure of the state and national governments to generate employment resulting in a glut in the labour market. 
In the fourth chapter I have adopted the reflexive stand of feminist scholarship in examining the reasons behind my adoption of a particular methodology and methods in the research, and the consequences that have resulted from it. I have also provided here an explanation of my positionality and subjectivity in conducting the research and how I felt this has affected the research process and outcomes.

In the fifth chapter I have analyzed the domestic maid's work from the perspective provided by the employers. The employers are looked on here as representatives of the civil society. My aim has been to find out how necessary the employers, as part of that society, view the work performed by the maids and the form of expression that they adopt. I also examine the conception of the maid as revealed by the employers and how they react to their reality, based on these conceptions.

I have taken a different vantage point, that of the first person narratives of the domestic maids, in the sixth and the seventh chapters. The main purpose of the sixth chapter is to examine the rewards of this occupation through an analysis of the everyday work experiences of the maids. In turn I also look into the active agency of the maids to withstand their situation through industrious means of resistance that they adopt and the varied consequences that follow as a result.

In a similar vein in the seventh chapter, I have looked at the domestic lives of the maids again borrowing from their narration. In this chapter my attempt has been to understand the impacts of paid work on the domestic lives of the maids. I have also taken a critical look of the altruistic model of the family as often, in the present context women's interests are subsumed within the family's needs leaving her in a weakened position to bargain from, vis-à-vis the male members of the family. Under such 
circumstances women can resort to limited maneuverings and subtle expressions of dissent as they bear the unequal burden of housework, childcare, cooking irrespective of their outside responsibilities as workers in the paid labour force.

In the eighth and the final chapter of the thesis, I have examined the beginnings and the progress of grassroots movements in India to bring about changes in the working conditions of domestic workers in the country. To gain first hand experience from within the movement, I have examined and participated in the activities of two NGOs in Kolkata and gauged the practical implications of their struggle. 


\section{Chapter -2}

\section{$\underline{\text { Re-examining patriarchy and domestic work in the Indian context }}$}

Comparative analysis of the conditions under which women work and the ways in which their work is defined is necessary both for explaining inequality and for shedding light on the ways in which women's inferior positioning in the workforce is reinforced or can be challenged (Sinclair 1991:2).

In order to understand the gendered nature of the labour market, it is necessary to conceptualize it as part of the social and economic structure in which it is entrenched. Within Indian society the ideological construction of patriarchy creates conditions for the subordination of women in a hierarchical structure (Kalpagam 1994:234). There is also a need to draw out the role played by the state in the construction of this ideology and the particular discourses that inform the plans and programs that the state formulates. A relevant example in this regard is the negative impact of India's New Economic Policy (NEP) that has created doubts as to its efficacy as a path to development. With runaway figures of poverty, violence and exploitation being perpetrated on the weaker majority, it can be claimed with a degree of assurance that development and what it stands for today has failed the poor, a significant part of whom are women.

I begin this chapter by examining patriarchy as a concept which has created and sustained the systematic impoverishment and neglect of large sections of Indian women. In the second section I look at the partial enumeration of women's work in official discourses at the national and international levels and provide a brief glimpse of the causes and consequences of such partial representation. In subsequent sections I have explored the relevant growth of globalization and the emphasis on the informal sector, which are the actively pursued developmental strategies in India today, and have used their implications for women as entry points for my investigation. Following this, I have 
used the concept of resistance, both at the individual and collective levels, to focus on the contests for power that have always accompanied its unequal distribution.

\subsection{Women in Patriarchy}

Empirical evidence suggests that women's position in the labour market remains weak as they remain subject to multiple disadvantages such as illiteracy, inadequate skill formation, lack of mobility, lack of assets and the like. As a result women are often compelled to stay in the informal sector against their will over the long term (Kalpagam 1994:234). Under such circumstances it is useful to think of a broader explanation for the exploitation of women. This is provided by the concept of patriarchy as manifested in the lives of these women.

Walby's (1990:20) definition of patriarchy as 'a system of social structures and practice in which man dominates, oppress and exploit women' is useful as such a definition is free from both 'biological determinism' as well as the flawed notion of every man occupying a 'dominant position' and every women a 'subordinate one'. Another merit of this definition is that patriarchy is recognized here to work through different structures, namely the patriarchal mode of household production, patriarchal relations in paid work, patriarchal relations in the state, male violence, patriarchal relations in sexuality, and patriarchal relations in cultural institutions. The use of more than one base for conceiving patriarchy has made it possible to span a whole gamut of inter-linked but at the same time autonomous structures that foster inequality between the genders. Further, Walby notes that although some changes in favour of women may currently be in the offing at different levels of the state and community, this has only led to superficial 
changes in its style of functioning rather than any discarding of the principle (ibid:20-21). Although this theory was conceptualized within the specific context of Western societies, I find it relevant to explain women's position as workers in Indian society as well.

As I will show in the subsequent chapters of my thesis, due to the patriarchal production relations in the family, where woman's role is predominantly that of wife and/or mother with the principal responsibility of running the household, poor women are left with little room to develop skills and have no option but to fester at the lowest rungs and in the least paid jobs at the labour market.

At work places, women are deemed to be 'unskilled' and therefore given low wages and replaced at will. As Philips and Taylor (1980, cited in Walby 1990:31) point out, the ability to label a job as skilled or unskilled has clear links to power - a resource not available to poor women workers who are robbed of social and economic recognition of their skills although technically they may have engaged in protracted periods of training to acquire them.

Also, the state has proved itself impervious to the needs of the underprivileged in India, especially poor women, through its partial recognition of women's work, its active perusal of policies of liberalization which disadvantage women, land reforms which ignore the rights of women, neglect of workers' rights in the informal sector where women are concentrated and the like, each of which I discuss in detail in the text that follows.

As a form of controlled female sexuality the seclusion of women, especially unmarried girls within the household, has a deleterious effect on their ability to gain recognition as workers. The limited outside contact that accompanies such seclusion, has 
prevented many of them from gaining information and skills valued in the market. Similarly they have been prevented from gaining any apprenticeship training which could be put to use later on. The major fallout of this practice is the lack of experience to form networks and organizations. The greater freedom of men in this sphere and their consequent greater successes at organizing is an indicator of the opportunities that women have had to forego due to the seclusion imposed upon them from an early age.

The issue of male violence, though not directly investigated during this research, has nevertheless made its presence felt in questions of income distribution at the family level and suspicions of theft at the site of work. The threat of male violence against female family members is often used as a check to limit control that women have upon the disbursement of their income.

Among patriarchal manifestations at the cultural level, the most potent form revealed during the research has been the lack of care and nurture reserved for women stretching from childhood to old age. As a case in point, we can look at the astonishingly low levels of literacy among women in India. As pointed out by Banerjee (2002:53), even in 1991 an astounding high seventy percent of the women of the age group of fifteen and above, have either been denied any form of formal education or left school after only three years. Many of the maids felt that their illiteracy restricted their choice to explore other avenues of income.

This is surprising given that in many instances, the Indian state has made special provisions for women as a weaker section of the population and in special need of 'protection' (Banerjee and Roy 2004:4831). Thus women have figured prominently as a specially targeted group for poverty alleviation, reproductive health improvement and 
literacy drives (ibid). Despite this, their continued presence, in large numbers, among the deprived groups mean that there is need to investigate the actual actions of the state and not what its 'promises' are and what it 'professes' to follow.

\subsection{The Discourse on Work}

The traditional definition of work has been activities carried out for 'pay or profit' (Raju 1993:2). Reproductive tasks that are not exchanged for a price at a market are not entailed as work (Waring 1988:28). This underlying meaning of work as something carried out for economic purposes has consistently pervaded national and international official discourses. Feminists have been concerned by the fact that between 'work' (which may not involve exchange of money) and 'economic activity' (which involves such exchange), the latter is given precedence in recognizing economic productivity (for example in the UN System of National Accounts (SNA)) ${ }^{1}$ (Raju 1993:2). To compensate for such bias, attempts have been made to broaden the definition of work that can be counted as economic activity. In 1982, the Thirteenth International Conference of Labour Statisticians held at Geneva adopted a resolution in this context which was to be implemented by all member countries of the United Nations (Bhattacharyya 1985:212). According to this document, 'work' involves 'the production of economic goods and services [which] should include all production and processing of primary products, whether for the market, for barter or for own consumption' (Anker et al. 1988:6). However despite these recommendations provided by the United Nations and the International Labour Organization (ILO), the SNA continued to consider only the part

\footnotetext{
1 The UN System of National Accounts is an integrated set of macroeconomic accounts, balance sheets and tables based on internationally agreed concepts, definitions, classifications and accounting rules. Together, these principles provide a comprehensive accounting framework within which economic data can be compiled and presented in a format that is designed for purposes of economic analyses, decision taking and policy making (UN, 1993).
} 
which deals with creating food as labour force activity (ibid:7). Accordingly, while activities like making of butter, cheese, husking of rice, grinding of grain are recognized as economic activities, cooking is not, though it is often very difficult to make distinctions between these activities (ibid). More recent versions of the SNA have continued to enlarge the definitional scope of 'work'. However, curiously, the qualification remains; that is, goods and services produced for one's own consumption is covered, provided that they are also marketed (U.N 1991:90). The 1993 revision also excludes activities like cooking for home consumption, cleaning, child care and elderly care at home as these cannot be compared to other services that can be marketed (U. N 1995:107).

In India, the main source of such official data has been the census studies conducted at ten year intervals since 1950 by the Government of India and the NSSO (National Sample Survey Organization). The three census years, beginning in 1961, conceptualized a worker as someone who is physically or mentally involved in economically gainful activities, overriding the previous definition of a worker as a person who has an income (Raju 1993:6). In the 1991 census there were specific instructions to include as workers those who provided 'unpaid work on farm or in family enterprise' (Office of the Register General and Census Commissioner 1991b cited in Raju 1993:7).

The NSSO has often been widely commended as a more receptive enumerator of 'employment status' in comparison to the Census in India'. It has developed a larger framework whereby 'domestic workers' were divided into two sub categories. In the first

\footnotetext{
1 The Census defines 'main workers' as those whose main activities was participation in economically productive work for 183 days or more in the previous year while 'marginal workers' are those who participate for less than 183 days in economically productive work. The NSS in comparison has at least three ways of capturing employment. The first is that of 'usual status' activity, which relates to what the person usually did in the course of the past year. The second is the concept of 'weekly status', which counts a person as employed if she/he was engaged in any economic activity for at least one hour on any day of the week preceding the survey. Finally, 'daily status' defines a person as employed if she/he has worked for four hours or more during the day preceding the survey (Government of West Bengal 2004: 90-93).
} 
group are workers who were exclusively engaged in 'domestic duties' (activity code no. 92) while the second category included those who attended 'domestic duties' in addition 'to free collection of goods (vegetables, roots, firewood, cattle feed), sewing, tailoring and weaving for household use' (activity code no.93) (NSSO 1988 cited in Raju 1993:3). Although the NSSO exhibits greater sensitivity in data collection procedures than the Census in this regard, it has been unable to break out of the quagmire of official preconceptions of 'who constitutes a worker'. For as Krishnamurty (1990, cited in Raju 1993:3) indicates, the NSSO denoted persons who gave affirmation to activity code no.93 as their main occupation, in the category of 'non-workers'.

\begin{tabular}{|c|c|c|c|c|c|c|}
\hline Year of census & \multicolumn{2}{|c|}{ Persons } & \multicolumn{2}{c|}{ Males } & \multicolumn{2}{c|}{ Females } \\
\hline & NSS & Census & NSS & Census & NSS & Census \\
\hline 1971 Census & & 34 & & 52.7 & & 13.9 \\
\hline $1972-73$ NSS & 40.7 & & 52.7 & & 27.8 & \\
\hline $1977-78$ NSS & 41.6 & & 53.4 & & 28.9 & \\
\hline 1981 Census & & 36.8 & & 52.6 & & 19.8 \\
\hline 1983 NSS & 41.8 & & 53.5 & & 29.3 & \\
\hline $1987-88$ NSS & 40.9 & & 53 & & 28 & \\
\hline 1991 Census & & 37.5 & & 51.6 & & 22.3 \\
\hline $1993-94$ NSS & 42 & & 54.5 & & 28.6 & \\
\hline
\end{tabular}

Table 2.1 - Worker Population Ratio by Sex, India (Census and NSS survey), 1971-94 Source: Pravin Visaria, based on census and NSS estimates cited in Mehta 2000:29

As Table 2.1 indicates, in the records prepared by both surveying agencies, more than fifty percent of the males are enumerated as workers while females are grossly under represented in this category. The census figures show an upward trend for women's participation over the decades but the rates continue to be less than half of those of men. Higher figures are returned by the NSS, but here too, female work participation rates have never exceeded the thirty percent mark.

From a perusal of literature available on the subject, Mehta (2000:30) has identified some of the causes for what she terms the 'statistical invisibility' of women's work. An 
important cause for such skewed data has been the bias of interviewers who have often been males. In subsequent years, although efforts had been made to reduce this bias by involving females in the task and better training of their male counterparts, the measures have not been fully successful. An additional problem has occurred when the responses have been collected from the head of the household who most often are male. Even when replies are compiled from women respondents, a number of problems persist. The cultural precepts which view women's participation in outside work as negative may cause many male and female participants to suppress such information. Secondly the numerical variety of tasks that women perform cannot easily be captured in questionnaires meant to record one main activity. Therefore domestic work, which remains an important component of work that women perform, might be the only activity reported as it may be done most regularly and consume a lot of time, while others such as dairying, fishing, poultry keeping or maintaining vegetable gardens, which are complementary activities, are not recorded (Mehta 2000:30).

Housework, which includes such tasks as cooking, cleaning, caring and the like, has been a persistent omission from both national accounts and labour force figures. Enumerators have been challenged in this regard by economists (for example Sen 1982 cited in Bhattacharyya 1985:205; Waring 1988:230-235) in the light of the fact that considerable time is spent by women in such tasks. Possible methods to estimate the work items in terms of their pecuniary values have also been suggested by some economists, for example time-use surveys ${ }^{1}$ (Bhattacharyya 1985:205, U.N 1995:108).

\footnotetext{
${ }^{1}$ A time-use survey captures in sequence all the activities of individuals over a fixed period of time, usually one or two days (UN 1995:105)
} 
However resistance to such measures has also been quickly applied, preventing their implementation. A practical problem is that, when domestic labour is included, the female employment rate climbs higher than that of men, creating a false impression of increased wellbeing among women, when in reality they are receiving no monetary returns for this labour (Bhan 2001:13). But such a conceptual illusion cannot remain the basis for ignoring such an important contribution by women towards society. Often the burden of housework prevents women from gaining entry into education or other skill enhancing training which can help them gain outside employment and therefore greater visibility in public life (Bhattacharyya 1985:206). There is need to make every attempt to recognize women as workers for their domestic work, with provisions of social security and union support provided to them (Bhan 2001:13).

The reluctance of official agencies to give adequate attention to this issue is a reflection of male bias in patriarchal structures. The low importance attached to female labour in India is linked to the subservient position that the society reserves for them so that it can ignore demands to give proper recognition to their labour and societal contributions. The conditions of work also leave much to be desired as women become more and more concentrated in poorly-paid low-end jobs originating from globalization.

\subsection{Women's work under the cloud of globalization}

The promise of globalization has been to ensure the free movement of goods and services, capital and resources across national borders and space to provide for the maximum efficiency in their utilization (Sharma 2004a:1). Though the intention has been to reduce borders, globalization has created more barriers for the entry of those without 
sufficient social, economic or political strength to participate in recognized economic activities. Thus, for example, in less developed countries, workers (with insecure work or earnings), social groups (tribal and aboriginal communities) and women (in general and especially from the lower socio-economic strata) have so far remained excluded from globalization's benefits, although their everyday existence has often been profoundly affected by the process (ibid:2).

India introduced economic reforms called the New Economic Policy (NEP) in 1991 (though the process had started to gather momentum from the eighties) following an escalation of the foreign exchange debt crisis. This was prompted by the fact that the economy had started to show signs of slowing down. The slowdown was accentuated by the liberalization of imports. Also policies in preceding periods, which included massive high interest and short term borrowings from international financial markets and a lack of the required financial restraints, had much to contribute to the economic situation (Krishnamurty 2000:4). In order to overcome this crisis, the government had to depend on Bank-Fund loans, thereby making it vulnerable to the 'conditionalities' forwarded by these loaning agencies (ibid). Pressure was applied by international bodies like the International Monetary Fund (IMF) and the World Bank for India to join the World Trade Organization (WTO) regime. While development-aid was the buzzword of the sixties, it has now been replaced by assistance in lieu of open markets (Kalpagam 1994:47). More than a decade after its first implementation, the SAP has contributed to exacerbating the cleavages that already existed between the regions, classes, castes and gender categories of India (Samuel 2001:114). 
Similar to other countries undergoing SAP, India had its currency (Indian Rupees) devalued by $25 \%$, experienced government cutbacks in public expenditure, decontrol and deregulation of goods and prices, slow growth of formal sector employment, enhanced poverty in the rural areas and among the urban poor, a severe cut in social development expenditures for housing, health and education, adoption of new technology and subsidies in agriculture (Kalpagam 1994:49, Dewan 1999, Dasgupta 2003). These were accompanied by privatization of government owned companies and of state or community held resources, and decontrol of labour protection leading to large increases of contract labour and subcontracting (Jhabvala and Sinha 2002:2037)

The logic behind the SAP was to facilitate those structural adjustments that would positively garner the country's entry into the globalization process. The success of the SAP was proclaimed when an annual growth rate of $6.5 \%$ of the economy was recorded by government economic surveys during the 1990s (Sharma 2004a:2). A poverty survey conducted in 2000 showed poverty down from $36.19 \%$ in $1993-94$ to $26.19 \%$ in 1999 2000 (Samuel 2001:114).

However these figures grow pale when we consider that as a result of population growth, the population below the poverty line remains more or less static at 265 million (Samuel 2001:114). Another disquieting development has been an increase in inequality in per capita expenditure between rural and urban areas (Sharma 2004a:14). This is an extension of the growing gap in wage/salary incomes between rural and urban areas (Deaton and Dreze 2002 cited in Sharma 2004a:14). Also in order to reap the benefits of globalization, India's workforce has to enhance its level of skills. This is evident from the 
very low wage rates for illiterate workers in the industrialized countries. This is a great challenge for India as 34\% of its population is illiterate (Basu 2004:17).

The impact of globalization on Indian women has been varied. While opportunities for better education and employment have improved the public participation rate of privileged groups of women from the elite classes, the majority of women from the lower classes have experienced a downward slide on the socio-economic ladder. The growing body of literature dealing with the impact of structural adjustment on rural women holds true for India as well, where there has been a continuous undermining of their roles in subsistence agriculture and petty commodity production (Dasgupta 2003:2-3).

\begin{tabular}{|c|c|c|}
\hline SAP Features & Effect & Impact on women's living \\
\hline $\begin{array}{l}\text { Cut in public expenditure } \\
\text { Expensive drugs }\end{array}$ & Poor health services & $\begin{array}{l}\text { No access to health care } \\
\text { Pre-natal mortality } \\
\text { Disease/illness } \\
\text { More health care at home }\end{array}$ \\
\hline $\begin{array}{l}\text { Devaluation of the rupee } \\
\text { Cut in PDS subsidy }\end{array}$ & High food prices & $\begin{array}{l}\text { Spend more time processing food } \\
\text { Low nutritional status }\end{array}$ \\
\hline $\begin{array}{l}\text { Underemployment } \\
\text { Unemployment } \\
\text { Low paid work } \\
\text { Wage freeze } \\
\text { Withdrawal of workers } \\
\end{array}$ & Low Income level & $\begin{array}{l}\text { Multiple jobs } \\
\text { Lower standard of living } \\
\text { Fall in real wages } \\
\text { Longer working hours } \\
\text { Slip below poverty level }\end{array}$ \\
\hline $\begin{array}{l}\text { Privatization } \\
\text { Deregulation } \\
\text { Delicensing } \\
\text { Recruitment of flexible labour } \\
\text { Closures and job loss }\end{array}$ & Insecure livelihoods & $\begin{array}{l}\text { Subcontracting } \\
\text { Retrenchment } \\
\text { Low bargaining } \\
\text { Insecure life }\end{array}$ \\
\hline
\end{tabular}

Table 2.2- Impact of SAP on poor women's living conditions in India Source: Adapted from the Economic Agenda Document prepared by the coordination unit for women NGOs, 1995 (Kishwar 1996:54) 
As indicated in table 2.2, the withdrawal of government social services is evident in spheres such as health ${ }^{1}$ and failure of the Public Distribution System (PDS) scheme ${ }^{2}$. The reduction in government expenditure on health means that as services grow costly, poor women are not able to access medical attention when required. There is a rise in maternal mortality and the lack of nutrition has resulted in high rates of anemia (Ray 2002:154). Patterns of foodgrain consumption showed decline from 476grams/day in 1990 to only 418grams/day in 2001(Government of West Bengal 2004:7). The NSSO data has also indicated that aggregate calorie consumption per capita decreased from just over 2200 calories per day in 1987-88 to around 2150 in 1999-2000 (ibid). Uncontrolled price increases in market goods has put them out of reach of poor women and their families (Ray 2002:154). The PDS scheme with its urban bias has ignored large numbers of the rural poor. The targeted population has also been cut drastically as it shifted from universal application to only the population below the poverty line (Samuel 2001:114). Another area where the impact of globalization has been profound is the increased participation of women in the informal sector.

\subsection{Women in the Informal Sector}

The first usage of the term 'informal sector' by the ILO in the early seventies was mainly aimed at gaining recognition and government support for a sector which was considered to possess a large employment potential at a time when the formal sector had a low rate of growth (Kalpagam 1994:230). However by the 1990s, the optimism seemed

\footnotetext{
1 Central and state government expenditure on health which was 1.11\% of Gross Domestic Product (GDP) in 1998-99 has been reduced or remained stagnant (Samuel 2001:115)

${ }^{2}$ Public Distribution Scheme in India is a rationing system which provides food grains at subsidized rates to population in rural and urban areas.
} 
to have become much more guarded as the ILO voiced its reservations against the "worst aspects of exploitation" and "inhuman working conditions in the sector" (ILO 1991:58). However there has been no deterrence in the growth of this sector with the maximum number of new jobs in the developing countries originating here. It has also made its presence felt in the industrialized countries (Castells and Portes 1989:12, ILO 2002:1). The initiation of structural adjustment programs in many third world countries has also provided a boost to the growth of the informal sector whose non-unionized labour force is considered to be a factor favourable to growth, unlike the formal sector (Kalpagam 1994:230).

The informal sector characterized by non-regulated exploitation is also viewed by some as an extension of classical capitalism instead of advanced capitalism (Castells and Portes 1989:13). The reasons for the persistence of this outmoded form of capitalism differ in different economies, that include the small size of a home market which restricts the industrial base and by extension the formal sector, exercise of the power of monopoly capital, the surplus supply of labour and the like (Kalpagam 1994:231). These factors can occur singly or in combination, leading to the growth of the informal economy. India's informal sector contribution to the economy stands at $60 \%$ of its net domestic product, $68 \%$ of its income, $60 \%$ of savings, $31 \%$ of agricultural exports and $41 \%$ of its manufactured exports (Sinha and Siddiqui 1999 cited in Harriss-White 2004:265).

As pointed out by Castells and Portes (1989), one of the principle reasons for the growth of this sector is its characteristic low labour costs. This is affected by the lowering or total exemption of social benefits payable to the worker, as well as employee related payments made to the state. Therefore, by suppressing labour costs and the allowing 
indiscriminate recruitment and lay-off of workers, efforts are made to increase the efficiency of capital (ibid: 30-31). An additional feature of this sector which calls for closer inspection is the large presence of women employees. In India they constitute up to $92 \%$ of the total workforce in the informal sector (Dewan 1999:427). Thus although women have become the main beneficiaries of such jobs, as recipients they have to forsake many privileges that are guaranteed to workers in the formal sector (Jhavbala and Sinha 2002:2039). Subcontracting and home based work in this sector has become a common feature as employer/managers escape bearing the infrastructural costs as well as the threat of workers organizing because of their dispersed locations. The very low pay delivered on a piece rate basis and irregularities of the work (ibid) are used as controls to keep the worker in a constant state of impoverishment and uncertainty.

'Shramshakti' (meaning 'the labour power'), the report of the Government of India Commission on Self Employed Women and Women in the Informal Sector has expressed anxiety for the workers in the sector as follows,

\footnotetext{
The areas of exploitation [in the informal sector] are high resulting in long hours, unsatisfactory work conditions and occupational health hazards. The organized sector takes advantage of this vulnerable position of the labour force in the unorganized sector. Large industries now find it advantageous to decentralize production units of large registered units (Government of India 1988:9).
}

The Commission has rightly pointed out that the workers in this sector lack basic rights. Some of these are low minimum wages and lack of maternity benefits, lack of crèche facilities for minor children, absence of compensation for any health hazard and so on (Mukherjee 2004:281). Again, the gender bias in wages is more acute in this sector as compared to workers in the organized sector (ibid: 282). The Commission (1988:190) reported that women's wage rates are half of (or even less) the wage rates for males. The bias has persisted. A survey conducted among informal sector workers in Ahmedabad 
city in Gujarat in 1998 has shown that the average daily wage rate for men stood at Rs. 47 while for women the common rate were less than Rs. 37 (Unni 2000 cited in RoyChowdhury 2004:107).

The domestic workers share with their peers in the informal sector all the impediments of low pay and irregularity in obtaining work (Jhabvala and Sinha 2002: 2040). The rapid growth of urban areas and the increased participation of middle class women in wage employment have meant that there is a great increase in demand for workers in services such as domestic work like cleaning, cooking, care of children and elderly (ibid). Poor women are mostly employed for such jobs. Thus the maids as petty agents of the globalization process replicate within their body and active agency, the tussles of empowering and disempowering forces that have come to define globalization especially in the economic south. This is not to suggest that globalization has been the sole cause for the continuing misery of the poor women in India, but only that SAP has been one of the many factors that has synergistically acted to reinforce these inequalities

Therefore, given the deprivations that women are subjected to by the state and the society, there is a need to examine the diverse reactions that they provoke among women. This diversity springs from the choices available in the unique situations in which individuals are, or their collective is, embedded. The variety and complexities of the enabling/disabling factors result in a multiplicity of responses ranging from covert resistance to organized movement. 


\subsection{From Resistance to Reconstitution}

The position of women at the bargaining table under a patriarchal structure is not a comfortable one. Sen (1987, cited in Elson 1995:6) has argued in his cooperative conflict model, that women and men enter into a shared family life as both of them stand to gain from the unified structure as a whole. However it would be wrong to conclude from this observation that such an arrangement is only positive. Women are not treated equally in such arrangements, and their rewards are not always commensurate with their efforts. Women can be unwilling partners, fearing that they would otherwise suffer a drastic fall in their standard of living due to the denial of resources that are often controlled by men. The greater incidence of poverty among female headed households in India is a case in point (Visaria and Visaria 1985:83). I attempt to extend this argument also at the site of work where the employee, the domestic maids and the employers all stand to gain when they enter into a work arrangement. The employers gain from appropriating the cheap labour provided by the maid. The maid who receives a low wage cannot desert this arrangement because of the lack of other options available to her. In a labour surplus economy, the lack of recognition of existing skills and obstacles in developing others which are valued in the market, prevents the maid from opting out of such an arrangement. A choice which is restricted to low paid work or no work and hence starvation, is actually no choice at all.

Given these constricted circumstances, one can surely expect rare cases of dramatic confrontations between the dominant (male members of the family, employers) and the dominated (domestic maids in their families and work sites). However it would be wrong to discount collective protests altogether, although I would say that some 
amount of groundwork has to be done before they can come into fruition on their own. This groundwork is provided by everyday forms of resistance, a concept very insightfully dealt with at length in the writings of James Scott. His espousal of such methods as foot dragging, dissimulation, false compliance, slander, arson, sabotage and so on as effective adaptations on the part of peasants to register their resistance against landlords while at the same time stopping short of more radical face-off, has resonance in the studies of the resistance of subaltern women ${ }^{1}$ (Scott 1985:29).

As Oldenburg (1992:25) observes, despite covert resistance becoming an object of investigation, the site of the home as the ground in which women use 'covert, nonconfrontational and even devious ways' in order to improve their survival chances, sway decisions, resolve disputes and protect self interest and those of their dependants, have not been sufficiently explored. In my research on the living and working conditions of the maids, I have tried to explore these 'hidden transcripts', which records the clandestine, secret and quotidian methods of resistance adopted by the maids to resist the walls of exploitation from closing in on them by escaping through its cracks and gaps. These transcripts, while authored by women, can also be against women who as employers are as much complicit as their male counterparts in perpetrating the exploitation of those that they employ as domestic workers.

Whether such individual acts of resistance can ultimately develop into a coherent, collective and open form of resistance is again a different question. Scott (1985:31) is of the opinion that such a transition is not an unknown one though comparatively rare. On the other hand Haynes and Prakash (1992:13) are of the view that these two forms of

\footnotetext{
${ }^{1}$ Subaltern consists of ,"Men and women among the illiterate peasantry, the tribals, the lower strata of the urban subproletariat." (Spivak 1988:283).
} 
protest represent a dichotomy between struggles which can be addressed against hegemonic manifestations of power (everyday resistance being more suited here) and struggles for autonomy which can become both overt and violent (dramatic confrontations is possible here).

Drawing in part from the two viewpoints presented above, it has been my contention that these two types of struggles are not mutually exclusive. While 'everyday resistance' is almost an instinctive form of self preservation that can originate from full, partial or even minimal consciousness of individuals, it always possesses the potential to become more organized at specific and special moments in time (for example in times of extreme duress or under charismatic leadership, for example the formation of WWF in India $\left.^{1}\right)$. Even where violent rebellions have occurred, more insidious means of resistance are not unknown in them (Chandavarkar 1992:111). In fact each complements the other and can be combined to increase their effectiveness.

In this study on the domestic maids of Kolkata I have made an attempt to collect these moments where everyday forms of resistance are slowly building their way to formations of greater community solidarity. These movements, which I study in greater detail in the last chapter, are gradually coagulating at the grassroots level and possess the promise of a gathering momentum of women's agencies which can ultimately make way for more meaningful changes in their lives than any official decree can ever hope to bring. This is not to suggest that these struggles have precise and assured paths which can confidently lead them to a more egalitarian set-up. However their significance lies in the

\footnotetext{
1 The WWF (Working Women's Forum) was founded by Jaya Arunachalam in 1978 in Madras to develop the potential of poor female workers in India's informal sector through a system of micro-credit loans. Her ideas have been influential in the reshaping of government's policy on development (Bangasser 2003).
} 
fact that they have been able to challenge in public the supposed repositories of power and reveal the chinks and cracks that they have etched out in them. 


\section{Chapter-3}

\section{Women's work: A historically contested issue}

Saying that women's unpreparedness for the labour market is responsible for their vulnerability in it may sound like blaming the victim... none of [the] decisions that cripple them as workers are made by women themselves (Banerjee 2002:54).

Paid work for a woman in India can be viewed as both the termination of a long struggle, as well as a beginning of a new one, that she encounters in her quest to realize her potentialities and exercise a choice of her own. It has to be realized here that this struggle was etched out in a multi fractured society riddled by differences of class, religion, region, caste and gender that have undergone changes in local meanings and connotations as a result of the intertwining of the historical, socio-political and economic processes being played out in the global arena.

Gaining economic independence in the form of wage work for women has been a precondition, though not an exclusive one, in women's struggle for equality (Savara 1986: 1). The failure of the Indian census reports to register the unpaid work done by women and thereby undermine their contributions to the economy has also been exposed in numerous micro studies (Lessinger 1990:130, Banerjee 1995:77). Field research in India has shown that it is women who remain most commonly associated with such activities as cooking, cleaning, childcare, dairying and fishing. Women, whether employed outside the home or not, have principally remained responsible for these social and economically reproductive tasks. 
As the low value of 'women's work' extends its hold in the gendered labour market where it undergoes transformation as a wage labour', this 'accepted' link is being threatened and negotiated. However we know that no struggle can be fought in a vacuum. There is a need to explore the particularities, the sequences and the preconditions which apply to the socio-economic and political fields of struggle, if its present manifestations are to be appreciated. Yet before attempting any such exercise it must be remembered that it would be wrong to consider the vast panorama of the Indian labour market as a homogenous and uniformly distributed field. Despite a prevailing trend, wide regional differences exist regarding women's visibility and participation in work which swings dramatically over time and space. While the northern states (Map 3.1), have low rate of women's participation in paid work, especially those of Punjab (2.8\%), Rajasthan (13.0\%), Uttar Pradesh (7.5\%), Haryana (6.0\%) and Gujarat (13.7\%), those of the south have much higher rates of female labour force participation for example, Tamil Nadu (25.1\%), Maharashtra (26.5\%), Karnataka (22.7\%), Andhra Pradesh (30.0\%) (Census of India 1991). A possible explanation for this regional difference is attempted by Everett (1979) when she contends that it is the residue of social changes brought about by Muslim rule in India which resulted in stricter adherence of purdah or seclusion of women. In some parts of the country like Northern India, which experienced Muslim rule for greater time periods, there was more intensive adherence to these traditions than in southern India which for the most part remained in the periphery of Muslim reign (Everett 1979:39).

\footnotetext{
1 An observation made in 'Shramshakti' provides credence to this trend - "One notices a tendency to categorize tasks generally done by women as being of a slightly inferior nature, warranting lower rates of wages. One notices this even in the fixation of minimum rates of wages" ( Government of India 1988:109).
} 
Map 3.1

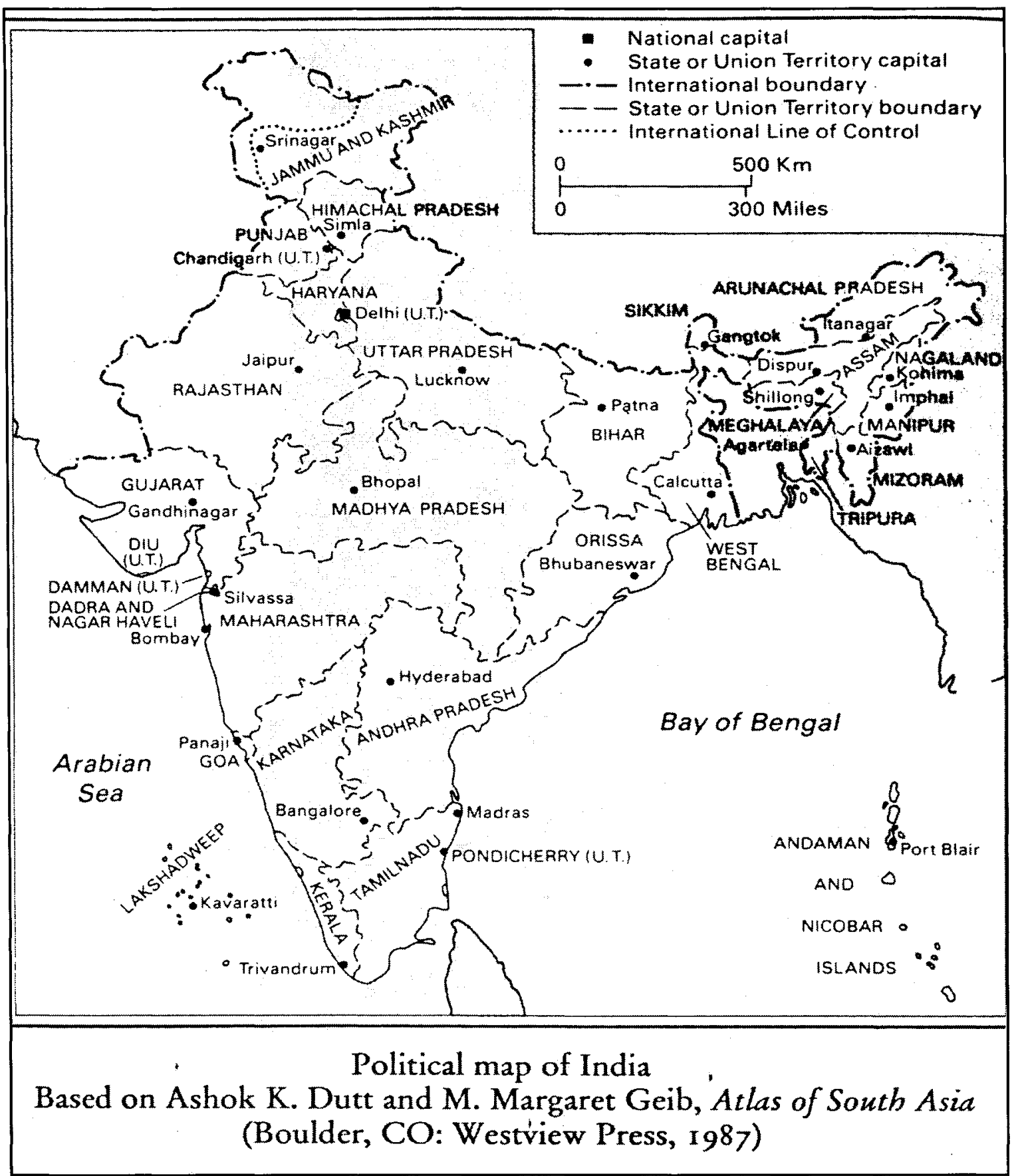

Cited in Brass 1994 


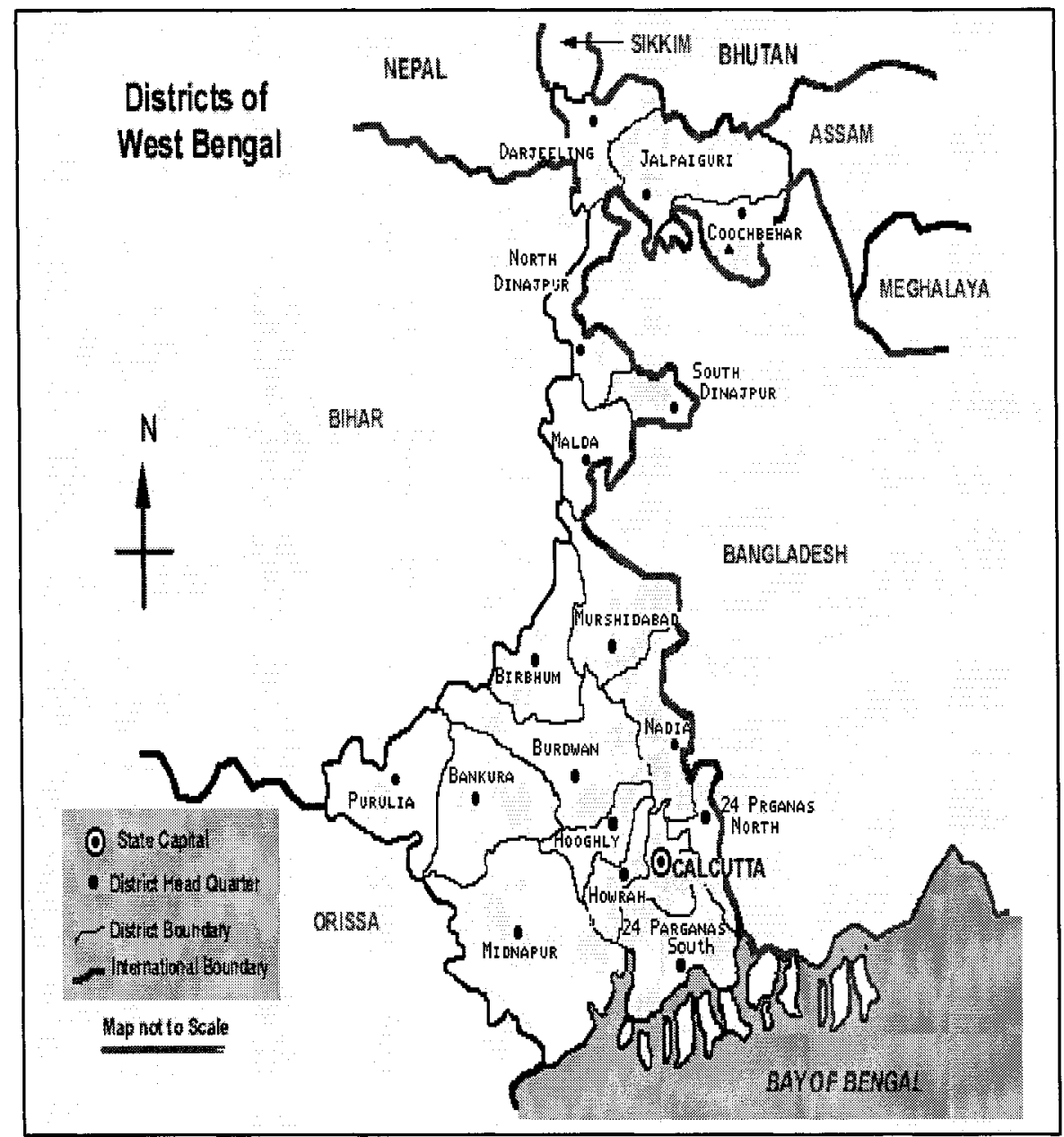

Map 3.2 - District Map of West Bengal

Source: National Information Technology Promotion Unit, Kolkata 
However this hypothesis has been recently contested by Dreze and Sen (2002:242244) who contend that this trend is an infiltration (in the Gangetic plains of North India) of upper caste norms within the lower strata of society. The former, as Kshatriyas ${ }^{1}$ or martial castes who specialized in warfare, had subjugated their female population as a legacy of pro male biases caused by their emphasis on violence. In this context West Bengal, a state located in eastern India with low women work force participation rates at $8.0 \%$ (Census of India 1991) requires a closer inspection of historical trends in order to gain a better perspective of the current conditions.

The purpose of this chapter is to provide an overview of the historical and contemporary context of women's position as workers and providers of their families from a social perspective, and the historical and contemporary influences that have affected their shaping. This is a process which has been fraught with struggles and contests over meanings and images, acted upon by a variety of cultural norms of diverse origin and varying expressions. Thus the first part of the chapter traces the historical stages of India with particular references to the development of the Bengali middle class under colonial rule. The second part deals with the current economic conditions of West Bengal which severely restrict women's employment prospects and how the ideologies held by the ruling coalition in West Bengal had failed to protect the interests of poor working class women who remain excluded even today.

\footnotetext{
1 The Rig Veda (an ancient Indian text written around $1000 \mathrm{BCE}$ ) describes the Kshatriya as a warrior caste as one of four castes within the Vedic system. Generally, the Kshatriyas are thought to be ranked second in hierarchy, the first being the Brahmin or priestly caste, the third the Vaishya or merchants and the fourth Shudra (menial or physical labourers) (Robb 2002:13). To combat the repeated foreign invasions into northern India, the kshatriyas gained importance in society in these parts. Their social norms were adopted by the lower castes over a passage of time. The experiences of the southern states were different as they were less frequently invaded.
} 


\subsection{Historical stages in the evolution of Women's work in India}

I have divided the historical period into three main divisions corresponding with the pre-colonial, colonial and post independence periods in India and have examined the social, political and economic factors which have affected or been affected by women's participation in work (external to their domestic duties - referred to as 'outside work' later) as it evolved through the various periods. However at this stage there is need to clarify the fact that the 'women' have been subdivided here into two categories i.e. the upper and middle class women forming one group and lower class women forming another. This subdivision is necessary in view of the fact that women's participation in outside work in India has been found by different studies to differ along class lines. While women from the lower class have greater outside work participation rates for economic reasons, women from the middle and upper classes have either never joined or were gradually withdrawn from such work as the family rose in economic and social status. Thus the experiences and struggles that these women faced and felt during the above mentioned periods have diverged along class lines. An exploration of both categories is required as they are the precursors of the employers and the domestic workers, who are the specific subjects of my research.

\subsubsection{Pre-colonial period}

Raju (1993:8) points out that the root of the social construction of women's role in the societies of South Asia where India is geographically situated, can be traced to the primary portrayal of women as wives and mothers whose main task is to nurture the family while man is the breadwinner. The next sequence to follow from this ideology is 
that the public domain gets reserved for men while women's participation remains confined to the private sphere of the home. The implications of such a separation of spheres gradually began to be felt in earnest at the beginning of the period of industrialization, when there was a shift in the location of production from the home to industrial areas. It became difficult for women to take part in these spatially separated domains as they remained primarily responsible for the household and reproductive activities (ibid). Women belonging to upper class households were discouraged from participating in outside work, although women from the lower class continued to do so for economic reasons. However even in the case of the latter, they could not travel far from home due to family responsibilities, resulting in restricted mobility which negatively affected their ability to diversify into profitable avenues of income generation. These women therefore continued to work as family labour either on family farms or in home based production activities like food processing, handicrafts and in the trade of their products (Desai and Krishnaraj 1990:49).

\subsubsection{Colonial period (1776 to 1947 )}

Some major changes occurred during the colonial period which spanned a period of about two centuries as India came under foreign rule, first under the aegis of the British East India Company (until 1857) and then under the British Imperial Crown (from 1858). Changes took place in the social, political and economic life of a nation which had begun to grapple with the realities of living under a foreign ruler. As a result, counter cultural and spiritual movements were formulated to fight off the hegemony imposed by these intrusions. The impacts of these changes on women profoundly differed according 
to their status and position in society. A closer examination of these different contexts in which upper and middle class and the lower class women lived, will provide a greater understanding of the different processes at work at this time.

One significant development was the growing influence of western ideas introduced by the British rulers which permeated Indian society. However the varied permutations and combinations of instances of local identities threw up a myriad of results. In Bengal and especially in its capital city of Calcutta, there was the rise of a new class and genre - the middle class or bhadralok (literally meaning gentleman) ${ }^{1}$. They owe their rise to the British rulers who required assistance to carry out their expanding colonial administration, a need that could not be fulfilled by the older aristocratic classes (Borthwick 1984:3). This middle class intelligentsia had a western education and acted mainly as intermediaries between the rulers and the masses in their capacity as clerks and junior administrators (ibid). They gradually expanded their economic strength and social prestige in the urban context of Calcutta which was the capital of the British empire in India until 1911.

A different picture emerges however when we consider the position of Bengali women in these households. They played a subordinate role as is evident from the observances of Raja Rammohan Roy (a social reformer of Bengal) ${ }^{2}$ who describes their purpose in the household only in the role of a cook, a sexual partner and a faithful housekeeper (Murshid 1983:21). The custom of purdah (female seclusion) was routinely followed as a well accepted norm among the females of the higher classes (Borthwick

\footnotetext{
${ }^{1}$ The bhadralok are distinguished by their refined behaviour and cultivated taste but not necessarily substantial wealth and power (Ganguly Scrase 2003:551).

${ }^{2}$ Raja Rammohan Roy (1772-1833) was a humanist and religious reformer, founder of the Brahmo Samaj who argued for the equality of woman (Robb 2002).
} 
1984:5). However some changes came about as a result of exposure to western ideas and the Bhadralok class began to question the backwardness of women or the Bhadramahila (women belonging to the middle class intelligentsia) in their society (Murshid 1983:25). Social reformers including Rammohan Roy, to members of the Radical Young Bengal ${ }^{1}$ or Ishwarchandra Vidyasagar ${ }^{2}$, all emphasized education to be the initial step towards women's emancipation (ibid:30). As Murshid (1983) notes,

Men who had for so long been satisfied with illiterate wives and who had never bothered about husband-wife relationships felt, for the first time, a communication gap between the wives and themselves (Murshid 1983:26).

As an outcome of the spread of female education and as a repercussion of the greater social changes in the nineteenth century which also resulted in greater economic stresses on family budgets, women started entering 'respectable professions' (bhadra kaj) like teaching and medicine (Murshid 1983:107).

Despite this above described sequence of events, it must be kept in mind that concepts of freedom and emancipation did not enter the minds of Bengali women until a much later date (Murshid 1983:110). Even during the early years of the twentieth century, the persistence of the goals among women to be better wives and mothers is an indication of the greater importance that society continued to attach to these roles (ibid:83). A possible explanation of this apparent dichotomy may be found in what Chatterjee (1989) calls the nationalist resolution of the women's question. According to Chatterjee, the rise of nationalistic fervor in India as colonial rule continued, resulted in the division of the cultural sphere into two: the material and the spiritual (Chatterjee

\footnotetext{
1 A name attributed to a group of radical free thinkers emerging from Hindu College, Kolkata in the early $19^{\text {th }}$ century known for their enthusiasm for things which are western and modern (Robb 2002: 223).

2 Ishwar Chandra Vidyasagar (1820-1891) was a philosopher, educator and social reformer who campaigned for widow remarriage and female education especially in his native Bengal (Robb 2002:238).
} 
1989:237). The nationalists reasoned that the material prosperity of the west, built on a solid foundation of science, technology and economic organization, had to be inculcated in order to challenge their dominance over the colonized. But on the spiritual front, they saw no reason to emulate the west as they saw the east to possess a superior spiritual essence which if preserved, would serve the nation better (ibid:238).

A close perusal of the nationalist discourse of this period records the conflation of the dichotomy of the spiritual/material with that of the inner/outer spheres of life (Chatterjee 1989:238). The material condition of an individual, which is distinct from his/her inner self, influences the adjustments that he/she has to make with the external world. However the nature of this adjustment can be mitigated by the spiritual awakening of the inner self (which is considered to form the essence of a being). Therefore compromises in values/traditions made in dealings with the external world would not propagate within the core of an individual. So long as the purity and sanctity of this inner self is maintained, a compromise of the outer self remains immaterial (ibid:239). While the outer space was identified with the outside world and the sphere of male activity, the inner space came to be represented by the home and the women who had embodied its representation from very early times (ibid). As Chatterjee states,

This completed the formulation of the nationalist project and as an ideological justification for the selective appropriation of western modernity it continues to hold sway to this day (1989:238).

While the outside world was one where the colonized was forced to accept regular disgrace and abuse, the inner sanctum of the home and the women in it were fiercely segregated as symbolic resistance to colonial hegemony (Sen 2002:467). Thus even though it was impossible to divert the direction of changes that female education and their consequent entry into outside professions was heralding, the emphasis was not to let 
it overshadow their spiritual or 'feminine' virtues, some of which were gentleness, family centered lives, religious observances and the like (Chatterjee 1989:243). Thus the liberation of women was to be enacted within the limitations set forth by the liberators which in effect acted as controls over their intellectuality, sexuality, mobility and labour power.

Among the lower classes however, women had greater freedom of movement and made greater contributions to the decision making parlance within the household (Murshid 1983:63). This was mainly the consequence of their greater share in the earned income as a result of their participation in outside work (ibid). Women were a part of the handicraft industry, which continued to be located in homes for a very long time (from approximately the twelfth to the sixteenth centuries) even when other production activities had moved out. A large number of women found employment in the hand spinning and weaving sectors which, next to agriculture, was the most popular mode of employment for women (Desai and Krishnaraj 1990:53). The handicrafts prepared by women ranged from the exquisitely beautiful chikon work in Uttar Pradesh to quilting in Bengal to tie and dye in Rajasthan to rug making in Sindh and Baluchistan (Twiff 1907 cited in Desai and Krishnaraj 1990:53). Other types of activities where women earned a livelihood include working on looms, rice dehusking, dairying, marketing of fish and vegetable, making of ornaments, mid wifery and laundry (Buchanan 1922 cited in Desai and Krishnaraj 1990). For the Bengal Presidency as a whole (which included the other two eastern states of Bihar and Orissa) the share of women making and selling goods was as high as $41 \%$ as late as of 1911 (Banerjee 1989:272). However this did not continue for long. Under deliberate colonial maneuvers, indigenous industrial production was 
gradually brought to a halt to make way for foreign made goods. The handicraft industries could not compete with imported machine made goods and started to shrink. The mechanized processing of rice replaced traditional dehusking tasks carried out by women (Desai and Krishnaraj 1990:56). Some of the other tasks where women lost heavily were handloom weaving, hand ginning, oilseed pressing, food processing (ibid: 57). The 1931 census documents the fact that women were increasingly losing their jobs in industrial employment, with domestic service the only alternative available to them apart from agricultural operations (Banerjee 1989:278).

The trend of employing servants in the colonial economy of Calcutta can best be described as a gradual process. With an increase in their involvement in the lives of middle class Bengali households, domestic servants came slowly to be accepted as an integral part of the family (Banerjee 2004:14). Census data sources provide evidence to support the popularity of this urban service in the late nineteenth and early twentieth century Calcutta. Banerjee (1989:278) uses census records of the period to argue that in Bengal, by the second decade of the twentieth century, domestic service accounted for about seventy percent of the women workers engaged in modern services.

\subsubsection{The Post Independence period (1947 to the present)}

To understand the post independence era we need to analyze the economic conditions of the region in the period preceding independence from British rule. Calcutta, which was the capital of undivided Bengal until independence, had a distinct disadvantage among the bigger metropolises in India in that it was the only prime city in the otherwise economically weaker eastern part of India (Goswami 1990:90). Thus it 
became the destination of migrating groups from its large hinterland who found employment as mazdoors (workers) in the jute and iron and steel and chemical mills of Calcutta (ibid). These migrating workers consisted chiefly of males as cultural taboos restricted women's movements, influencing their response in ways that were different than their male peers (Banerjee 1989:289). As a result, the urban sex ratio underwent a steady dip until 1931 (ibid: 281). After this period, there was a change in the composition of migrants that was triggered by the slowing down of agrarian growth in the countryside of rural Bengal (Goswami 1990:90). This dislocated rural population had a substantial female component, consisting of both displaced agricultural labourers and their families, who arrived in the city and were absorbed as domestic servants, low paid workers or in extreme cases, as beggars (ibid).

In 1947 India's Independence from two hundred years of British rule was only a mixed blessing for Bengal as the independence coincided with Bangabhanga or the partition of Bengal. The roots of partition lay in the existing agricultural set-up which had a large religio-social divide in that the peasants who formed the numerical majority were Muslim while the landlords who were fewer in number were mainly Hindu. This divide had not previously been a line of antagonism between the communities but, under the manipulation of the British rulers, it began to swell into a frenzy of communal passion (Chatterjee 1997:31). The partition of Bengal into two parts was the result, whereby the Muslim majority in the east joined the newly formed Muslim majority state of Pakistan while the Hindu majority in the west joined secular India. This partition and the communal flares which accompanied it resulted in bloodshed and there was a great physical uprooting of the Hindu landlord class from East Pakistan which began to make 
its way towards the urban centers of West Bengal and mostly to Calcutta (ibid:65). According to the 1951 Census Report of India, there were as many as 3.5 million East Bengal refugees in the total population of West Bengal, and one out of every four person in Calcutta was a refugee (Chakrabarti 1990:3 cited in Bhattacharya 1999:327).

This new migrant stream was distinct from its predecessors in many ways. They originated from the same elite classes of landlords and intelligentsia as the resident bhadralok class of Calcutta and were as organized and articulate as the latter (Goswami 1990:92). Refugee colonies sprouted up quickly near the spacious and prosperous neighbourhoods of south Calcutta such as Dhakuria, Chetla and Jadavpur (ibid).

The agrarian rural sector of the economy of West Bengal had also suffered as a result of partition. The farming areas had decreased to only a third of their former size (Goswamy 1990:94). In addition, the influx of a large refugee population along its porous border had resulted in a massive expansion of population in all the border districts of East Pakistan, presently Bangladesh (Map-3.2), namely the 24 Parganas, Nadia, Maldah, West Dinajpur and Jalpaiguri (ibid). There was tremendous pressure on the amount of available land, resulting in a plummeting land-to-person ratio with a concomitant decrease in per capita food provisions (ibid). As a result urban migration also continued throughout this period. A further phase of population inflow was added during the liberation war of East Pakistan which resulted in the birth of the state of Bangladesh in $1971^{1}$ as another large bout of cross-border migration occurred (Chatterjee 2004:389). One important consequence has been the growth in the availability of labour in the context of shrinking

\footnotetext{
1 During partition of India, Pakistan as a country was formed by dividing the state of Bengal in the east and Punjab in the west. Pakistan was created out of Muslim majority territories in the west and east and India was created out of the vast Hindu majority regions in the centre. The western zone was called West Pakistan and the eastern zone (modern day Bangladesh) was called East Bengal and later East Pakistan. The Bangladesh Liberation War was an armed conflict between West and East Pakistan where the Indian military supported Mukti Bahini to form the separate state of Bangladesh. The war started on November 21, 1971 and lasted for roughly four weeks (Sisson and Rose 1990:214).
} 
resources. The result has been great exploitation of the poor and especially of poor woman.

\subsubsection{Effect of the partition on middle class women}

The ties that bound middle class women to the seclusion of their homes had, as indicated earlier, relaxed to some extent in the early part of the twentieth century. These ties were further weakened during the era of partition when refugee families shorn of their land began to grapple with the prospects of pursuing employment to earn a living. Commensurate with similar experiences in other parts of the world, women were most affected with the trauma of partition as they were the ones who carried the burden of responsibilities for day-to-day living (Bagchi 1990:42). Thus the outward orientation to find a job to support the family was almost like a progression of their 'natural' roles and came to be accepted to a greater degree than before. Nonetheless, this movement was in no way a smooth transition but was fraught with a multitude of obstacles emanating from family, society and the state. Since the cause for the greater participation of middle class Bengali women at this time was mainly economic vulnerability rather than social emancipation, their reproductive responsibilities continued at home as the double workday became a part of their daily life. The enormity of the burden increased all the more so in the case of lower income families (ibid: 44).

\subsection{Focus on West Bengal}

A focus on the current social, economic and political scenarios in West Bengal is necessary to understand the present position of women in this region. West Bengal 
remains distinct from the other Indian states because this state along with Punjab in the west had to undergo a division of territory during partition which had a great impact on its economy and society. Secondly as it has been the only state to be ruled by a coalition of Left Parties for a long time, it has followed a path of economic growth distinct from the other Indian states.

\subsubsection{Economic recession and women's prospects}

The economy of West Bengal has experienced a gradual slowdown in industrial growth rates in the post independence period. According to the Planning Commission of India, the proportion of population living below the poverty line in the state stood at $31.85 \%$ in 1999-2000 (Government of West Bengal 2004:4). West Bengal has been governed by a coalition of left parties (Left Front) for nearly three decades (from 1977 to the present), making it the longest serving government in post independent India. During the tenure of this government, the economy of the state has undergone several changes. The most lauded achievement of this government has been the implementation of land reforms leading to an increase in agricultural production; however the most notable failure has been in the area of industrial growth (Banerjee et al. 2002:4203). A closer look at these two important sectors of the economy will help to illustrate their impacts upon the employment prospects of women and on poor women in particular.

In the case of agriculture, West Bengal under the Left Front government surged from its 1970s position as one of the laggards in agricultural production in India to becoming, in the 1980s, a state with a rapidly expanding agricultural production growth rate of $6.5 \%$ (Saha and Swaminathan 1994 cited in Banerjee et al. 2002:4212). The credit 
for this turnaround was claimed to be the consequence of the successful implementation of 'Operation Barga', whereby agricultural land exceeding the land ceiling was redistributed among landless and the rights of sharecroppers were secured ${ }^{1}$ (ibid).

In sharp contrast to agriculture, state industries have undergone a decline during the reign of the Left Front government. An idea about the gloomy industrial scenario of West Bengal can be gleaned from the fact that the state's share in India's industrial production registered a sharp decline from $9.8 \%$ (1980-81) to 5.1\% (1997-98) (Banerjee et al. 2002:4203). Another indication of its dismal performance on the industrial front is evident in the fact that industrial capital investment in West Bengal in the period between 1984 and 2001 increased only fourfold whereas for the rest of India, it grew seven fold (Statistical Outline of India 2003-04 cited in Guruswamy et al. 2005:2153). Also, the growth in the number of industries during the above mentioned period has been quite negligible- from 5369 to 6091 - while the corresponding figures for the country as a whole were 97,000 and 1,31,000 respectively as is shown in Table 3.1 (ibid).

\begin{tabular}{|l|c|c|c|c|c|c|}
\hline \multicolumn{1}{|c|}{ States } & $\begin{array}{c}\text { No of } \\
\text { factories }\end{array}$ & $\begin{array}{c}\text { Invested Capital } \\
\text { (Rs Crore) }\end{array}$ & Employees & $\begin{array}{c}\text { Gross output } \\
\text { (Rs Crore) }\end{array}$ & $\begin{array}{c}\text { Net Value } \\
\text { added } \\
\text { (Rs Crore) }\end{array}$ & $\begin{array}{c}\text { Net Value } \\
\text { added } \\
\text { (Per Cent) }\end{array}$ \\
\hline AP & 14,029 & 39,121 & $7,64,000$ & 61,347 & 8,879 & 6.2 \\
Bihar & 1,535 & 2,920 & 49,000 & 7,225 & 729 & 0.5 \\
Gujarat & 14,090 & 93,001 & $5,54,000$ & $1,27,977$ & 16,856 & 11.7 \\
Karnataka & 7,010 & 35,685 & $3,59,000$ & 46,259 & 8,302 & 5.8 \\
MP & 3,221 & 19,733 & $1,91,000$ & 36,721 & 6,208 & 4.3 \\
Maharashtra & 18,528 & $1,03,631$ & $8,17,000$ & $1,84,971$ & 31,261 & 21.8 \\
Tamil Nadu & 20,601 & $\mathbf{5 5 , 7 8 5}$ & $9,25,000$ & $1,03,539$ & 16,536 & 11.5 \\
West Bengal & $\mathbf{6 , 0 9 1}$ & $\mathbf{2 5 , 2 2 1}$ & $\mathbf{4 , 5 6 , 0 0 0}$ & $\mathbf{3 9 , 1 8 3}$ & $\mathbf{5 , 6 9 9}$ & $\mathbf{4 . 0}$ \\
UP & 9,635 & $\mathbf{4 9 , 0 1 0}$ & $\mathbf{4 , 0 2 , 0 0 0}$ & 64,854 & 9,577 & 6.7 \\
Punjab & 7,131 & 15,008 & $2,78,000$ & 35,018 & 4,300 & 2.9 \\
India & $\mathbf{1 , 3 0 , 7 9 0}$ & $\mathbf{5 , 7 1 , 5 8 1}$ & $61,21,000$ & $9,26,345$ & $1,43,469$ & 100.00 \\
\hline
\end{tabular}

Table 3.1 - Statewise selected Industrial characteristics of India (2000-01) Source: Statistical Outline of India, 2003-04 (Guruswamy et al. 2005:2153)

\footnotetext{
${ }^{1}$ However the NSS data indicate that the proportion of landless rural households in West Bengal increased from $39.6 \%$ in $1987-88$ to $41.6 \%$ in $1993-94$, to as much as $49.8 \%$ in $1999-2000$. In other words by the end of the decade nearly half the rural household were landless. It is possible that the growing difficulties associated with cultivation across India - rising input prices and stagnant crop prices, the reduced access to institutionalized credit and other agricultural extension services - have made farming a less attractive avenue of economic activity in West Bengal. Also the very small sizes of the distributed plots have made them economically unviable to farm resulting in many of them being sold off subsequently (Government of West Bengal 2004:39-42).
} 
A particularly distressing figure has been the decline in organized sector employment, especially organized private sector employment from 10.84 lakhs in 1980 to 7.99 lakhs in 1997 (Banerjee et al. 2002:4203).

Economists put forward several reasons to explain this lackluster performance: external factors like partition which severed the link between raw materials and markets; the gradual decline in demand for jute products (one of the most established traditional industries of the region); or the funds which the Central Government has failed to provide to modernize the aging industries of the state (Guruswamy et al. 2005:2153-2156). Other economists have held the state government responsible for the plight of the industrial sector through its inefficiency in collecting taxes to finance their modernization or building up infrastructure to attract industries (Banerjee et al. 2002).

A critical look at both these developments in West Bengal's economy will provide an idea of its implications for women's employment prospects. A fact about the land reforms carried out by the West Bengal government which is worth noting is that they have mainly benefited the peasants in possession of medium sized plots of land, generally not exceeding five acres, while the marginalization of the rural landless has continued (Roy 2003:28-9; Bandhyopadhyay 1983 cited in Chatterjee 1997:48). The rural landless, many of whom were women, therefore were not the beneficiaries of the land reform program and continued to eke out a living as agricultural labourers.

Again, as Gupta's (2002:1748) research of the impact of land reform on women in two districts of West Bengal has shown, it was only in August 17-20, 1992, fourteen years after the first land reform program was started, that the government passed a directive providing joint titles for land in favour of married couples. However it 
exempted those distributions carried out prior to that date. While this indicates some grounds of concern for the excluded women beneficiaries in the preceding period, the following period also does not provide much ground for hope. Gupta reports that there has been a continued reluctance on the part of bureaucrats and peasant unions to protect the rights of women ${ }^{1}$ (ibid:1749).

While the above discussion seeks to critique the institutional flaws of the land reform program, the following deliberation attempts to gauge the impact of the increase in agricultural production indicated earlier. Banerjee et al. (2002:4212-3) notes that the production increases have been made possible through the replacement of traditional varieties of crops by high yielding varieties of rice, and by an emphasis on growing of cash crops like oilseeds and vegetables. Research in this area (for example Agarwal 1988b) has demonstrated how the growth of high yielding varieties of crops with their greater dependence on machine farming and heavy use of pesticides has resulted in the loss of female labour, previously employed in manual sowing, weeding and harvesting operations. My research on the lack of alternate employment prospects available to the maids, many of whom were displaced agricultural labourers, provides proof of this ongoing dislocation of women from the agricultural sector as a result of the development process which has resulted in a further contraction in their employment prospects.

\footnotetext{
1 Two clauses of the government order of 1992 express lack of seriousness and determination in regard to distribution of joint ownership of land. They are (a) if a female member of the beneficiary household is eligible for distribution, and (b) land should be jointly distributed to the extent possible. The 'if' and 'to the extent possible' were not clearly spelt out. Such hesitation and reluctance had not been expressed when land was distributed to the male heads of beneficiary households. (Gupta 2002: 1749)
} 


\title{
3.2.2 The state as a mediator for women
}

In this sub-section I investigate the role that the state has played in facilitating or impeding the status of working class women, such as maids, in society at large, in the context of the political economy of West Bengal.

As workers in the private sphere, these maids are 'hyperfeminized', a description used by Marchand and Runyon (2000) to account for the invisibility of workers in this sector, which perhaps legitimizes their low wages and their absence from the discourses of power. The truth of this description does not fade even when applied in a state like West Bengal which is under the rule of a left government. The Left Front's handling of gender issues will provide clues to their possible inclusion/exclusion in discourses. This is what two academics had to say when asked to comment on this issue.

\begin{abstract}
Among the higher, middle and lower classes, it is the middle class which employs them (maids). When there is such a contradiction of interest, the political parties here back the middle class. In my opinion this is the major reason why the dissent is not taking the shape of a movement ...It is a case of vested interests. There may be another reason. There is a gender bias in it. In our country still those occupations which are female dominated, there the organizations are weak. This is true cutting across party lines. This is historical. Even in a Marxist ruled state like West Bengal there is uneven sharing of power. (Dr. Ajitava Roy Chowdhury, Personal Interview) ${ }^{1}$
\end{abstract}

One reason for this may be the fact that political parties try to establish their bases over pre formed groups rather than starting from scratch. The maids lose out here because they never had this base. They also had very little time. Secondly there is a lack of perception of women as workers. Traditionally they [political parties] have never considered women as workers. They still don't, even today. (Dr. Nirmala Banerjee, Personal Interview $)^{2}$

As commented above, there are a number of factors which has contributed to shaping the state's response to the needs of poor women like the maids. A very important point to emerge is the electoral provisions that guide the actions of a party in a

\footnotetext{
${ }^{1}$ Dr. Ajitava Roy Cowdhury is currently a reader in the department of Environmental Economics, Jadavpur University, Kolkata, India.

${ }^{2}$ Dr. Nirmala Banerjee is former professor of Economics at the Centre for Studies in Social Sciences, Kolkata, India.
} 
parliamentary democracy like India. The $\mathrm{CPI}(\mathrm{M})$, the Communist Party of India (Marxist) which is the chief constituent party in the Left Party coalition that governs West Bengal, has a bhadralok leadership and a middle class base (Basu 1992:52). In an effort to conserve this power base, it avoids alienating its captive electorate by not focusing on issues inimical to their interests. Organizing the maids, whose service is used mainly by middle class employers, will therefore run counter to this reasoning.

An equally persuasive notion which has marked itself through its absence is the concept of women as workers. An important reason for the absence of organizing bodies among women workers, especially in the unorganized sector, is the lack of time in the lives of these workers that they can devote to such organizational efforts. This has made them unattractive targets for political parties which do not view them as a reliable electoral base. Even in cases where a separate women's cell exists, they do not pay adequate attention to the needs of women as workers as they recognize women only in their roles as wives and mothers (Basu 1992:55). The PBGMS (Pashim Bangla Ganatantrik Mahila Samiti or the United Democratic Bengali Women's Organization) which is the women's wing of the CPI(M) party mainly addresses 'social' issues indicating its bias of regarding them as women's issues, while leaving CITU (Center for Industrial Trade Unions), the trade union controlled by the party, to deal with 'economic' issues among the overwhelmingly male worker members (ibid:74). This segregation betrays the party's bias towards women's role. It willfully ignores the greater work participation of lower class women. The CITU, by ignoring the informal labour market where the women workers are concentrated, loses out a large potential base of support. The very low wages and inferior working conditions that plague the workers of this 
sector provide fertile ground to nourish union activities, but they are left in the doldrums due to the lack of acknowledgement by established workers' organizations (ibid: 75).

A third point which remains implicit but nonetheless is present is that the Left parties are reluctant to acknowledge women as a separate interest group in order to invoke the support of the traditional entity of the family. This has been most evident in its implementation of land reform measures discussed earlier. By bestowing land titles in the name of household heads, most of whom are men, the government has reinstated the economic disparity between the sexes and created additional space for male domination within an overarching patriarchal social structure.

\subsection{Conclusion}

In this chapter my effort has been to expose some of the issues which control women's entry into the labour market and the context in which they are implanted. The participation of women in the labour market has been influenced by various factors in historical and contemporary times. The role of the state and the market has negatively affected the marginalized women in the unorganized sector. The effect has not been the same on all women as a few have been able to benefit from these processes and acquire upward social mobility while the greater number has experienced a downward slide in their standard of living. These differences have prompted one class of women to utilize the other through the mediating structure of the service sector. Domestic service is one such service, which I look into in detail in the subsequent chapters beginning with the study of the employer's home where the work site is situated, to the issues that govern the lives of the women engaged in domestic service. 


\section{Chapter-4}

\section{Research Methodology: Developing a suitable methodology and documenting the research process}

Qualitative methodologies are a means by which the 'messiness' and complexity of everyday life can be explored by using research methods that do not ignore such complexity but instead engage with it (Dwyer and Limb 2001:2).

The influence of post modernism has left its undeniable mark on feminist discourse. Issues of representation have emerged as an important area of contestation. Criticisms have been leveled against tendencies in feminism of continuing to uphold the western middle class experience, in contexts that differed from it in relation to race, class, and sexual orientation. Third world feminist critiques also justifiably pointed to the misconception of homogeneity existing among all women and lack of difference in their representation in western texts. This was accompanied by challenging false claims in ecofeminism of an essentialist 'caring' and 'nurturing' disposition of women as opposed to men (Raju 2002:173). Each of these issues had relevance in my quest for a suitable methodology for the purpose of this research.

This chapter therefore begins with a brief perusal of relevant feminist literature. It is followed by a review of three key themes underpinning this research: positionality, subjectivity and power. I then discuss the research process proper, and my reflections on it form the conclusion.

\subsection{Searching for a suitable methodology}

One of the significant contributions of post modernism has been to cast doubts on an individual's capacity to perceive 'truth' (Parpart and Marchand 1995:3). Since experiences are borne out from precise contextual and historical positions, their 
subjectivity cannot be avoided (ibid). While the underlying assumption for the feminist movement has been to distinguish a separate female voice from the male, it has fallen short in capturing the differences which may lie among women. With 'difference' among women becoming an important rallying ground, feminists have had to contend with fragmentation among their ranks. Women, who had felt marginalized by the white, middle-class focus of the movement, sounded a clarion call for feminists to take into account differences of colour, class, ethnicity, sexual orientation- issues which had so far been ignored. Jhappan therefore contends,

Given centuries of economic and cultural imperialism, the ideology of white supremacy, patriarchy, and the concomitant oppression of certain cultures... theories which pretend to universalistic application must be discarded in favour of more complex, layered analysis which account for the multifaceted intersections of race, gender, class and other variables. Such theories must give space... to experience, subjectivity and political agency (1996:22).

Women therefore, with their varied life experiences, cannot be expected to focus on common concerns or issues of interest and any claims on behalf of a universal discourse cannot but bring about a premature closure of a complex and multilayered diversity. Thus, while concerns of the "male-breadwinner, dependent female, post-Industrial Revolution family form of the west" has formed repeated themes of research in feminist scholarship, other concerns like slavery, discrimination, poverty, which are a part of the historical and contemporary experience of many women, have found few mentions (ibid:23). Jhappan has also alluded here to the implicit relation of dominance and subjugation between the liberated (superior) western woman and the colonized (inferior) 'other' woman.

Feminists from the third world have also laid bare the falsity of a homogenous category of third world women having a common experience of oppression emanating 
from gendered identity and underdevelopment (Parpart 1993:444). Chandra Mohanty has raised this issue in her writings,

Scholars often locate "third world women" in terms of the underdevelopment, oppressive traditions, high illiteracy, rural and urban poverty, religious fanaticism and "overpopulation" of particular Asian, African, Middle Eastern and Latin American countries... Besides being normed on a white western (read progressive/modern) non western (read backward/traditional) hierarchy, these analysis freeze third world women in time, space and history (1991:5-6).

Third world women, when viewed within these rigid frameworks, lose out on two counts. First they appear as poverty stricken, helpless, weak and lacking in agency, in contrast to active, modern, educated, western women. Again by remaining undifferentiated, researchers reiterate the image of a passive, hopeless aggregated body. Inequities and differences stemming from their respective positions in class, caste or religious hierarchies, or regional and cultural specificities, and the effect of time on any/all of these categories, recede to the background in such analyses. While limitations originating from their embeddedness in a particular structure may conjure up common bonds among third world women, the elite often have the option of exercising its advantages in social, economic or educational fields to avoid the traps of patriarchy which are more binding on the poorer kin (Parpart 1993:454).

The determination of black feminists and feminists of colour to make their voices heard in the movement had a gradual effect. Their issues and viewpoints became an important contribution to the movement (Narayan 1997:126). In order to broaden the narrow base, there was an incorporation of the political and cultural concerns of women from the third world in the theoretical and practical fields of the movement (ibid). Thus there has been a growing trend in the movement to give attention to the politics and epistemologies of location, positioning and situation of both the researched and the researcher (Haraway 1991:195). It has been an admission of the partial nature of 
viewpoints which is a much more judicious assertion of knowledge than claims of universality (ibid). They are opposed to accounts which are ahistorical and make claims of transcultural applicability. As pointed out by Fraser and Nicholson, modes of theorizing in feminism which are foundationalist in nature and claim to be objective, can be called quasi-metanarratives as they make "essentialist assumptions about the nature of human beings and conditions of social life" (Fraser and Nicholson 1990:27). The amendment has to come from theories grounded in historical trajectories and adjusted to specific cultural groups and periods (ibid: 34$)$. When the category of 'women' has been redrawn with adequate room for difference that need not be contained or limited in any way, only then can such a categorization remain permanently open and significant (Butler 1992:16).

Such a restructuration of post modernist feminism would need to evolve its own methods of enquiry designed to its particular needs. This approach would require the adoption of multiple and innovative methods suited to the task and situation at hand instead of being limited to a single 'appropriate' method (Fraser and Nicholson 1990:35). Therefore there is need for feminists "to listen to themselves and to other women" as they speak of their everyday life experience and the significance that such narration holds (Harding 1992:188). While gender concerns remain an important area of investigation, this focus should never diminish the need to examine other interspersed facets of exploitation embedded in class, race or sexuality. It is equally important to capture attempts or acts of resistance and contestation of power that occupy a fluid and oscillating position, and the consequences that follow from them. Adoption of such methods may not be a guarantee to "reinventing ourselves as others" but it provides a clarification of 
the position from which the speech and action emanate and conveys an honest effort on the part of the researcher to admit his/her responsibility in the scheme of the research (ibid: 188-9).

\subsubsection{Positionality}

Critical analysis begins with an evaluation of one's own standing as a product of multiple confluences of social, political and historical processes that leave behind a multitude of traces (Gramsci quoted in Narayan 1997:21). In all likelihood, this finds a reflection in one's own intellectual musings. As Abu Lughod (1993:15) reminds us, a story is always situated; it has both a teller and an audience. Its perspective is partial and its revealing is motivated. A story retold will always bear the signature of the researcher and his/her concerns and priorities which themselves are flexible and subject to negotiations. Thus a note of caution has to be sounded when speaking for others, as there lies a real danger of imposition of personal values causing inaccuracies to creep into the research. I needed to ask myself therefore, where do I, the researcher, stand in the context of my research?

I am a thirty-two year old woman and a citizen of India. I was born and brought up in a middle class Bengali family of Kolkata. I immigrated to Canada about two years ago with my husband. Since then I have been engaged in pursuing a Master's degree in the social sciences, in a Canadian University. I had known the members of the community of the maids (some of them closely), the subjects of my research, since my childhood and have had a close association with them during various stages of my life. Yet I cannot claim to be an 'insider' to the community of domestic maids who have 
shared their life and thoughts with me during the course of the research. For all purposes I belonged to the 'employer-class' and could not claim to speak as the voice of these marginalized women. I also cannot deny that I had received training to conduct this research from a Canadian University and the academic writings based on this work will reach an audience which, realistically speaking, may not include any of their members. My authority to represent them in my research and analyze their situation stands to be repudiated on such counts. Thus one of the most fundamental contradictions in feminism is encountered, as questions of representation are poised to negate any enquiry that does not arise from within the particular community that is the subject of the research.

There is no way in which one can deny the relevance of the question of representation. However taken to an extreme, it can lead to an infinite fragmentation and a weakening of the feminist movement which has its aim in defending women's rights. There are also practical and logistical problems involved in bringing to the fore the voice of the marginalized. As Raju (2002:174) points out, there is a possibility that such a voice fails to make itself heard as it cannot communicate in a language which can gain an audience for itself amongst the decision makers. Under such circumstances, it becomes the moral and ethical responsibility of the privileged to speak out despite the obvious limitations that such a different perspective will have to allow.

The need is therefore to replace the search for identity with an acceptance of difference. As Mohanty (2003:226) rightly claims, no border or boundary can ever be constructed to bring about absolute separation. The challenge is to establish connections and redefine coalitions as a pragmatic exercise. Young (1997, cited in Edwards and Mauthner 2002:26) has proposed what she calls an 'asymmetrical reciprocity' in that, 
although it is impossible to comprehend the total implications of another's position, there still remains a scope for partial understanding gained through exchange. Instead of denying or glossing over power differentials, there is a need to attend to them (ibid). A continuous vigilance is required to make this process of dialogue in research legitimate and credible.

The clarification of a researcher's position is a valuable addition in critical feminist work. It provides for an improved perception of the diverse premises and judgments made by the different participants that is now brought within the domain of the research (Myrdal 1969 cited in Mbilinyi 1992:56). My position as an educated urbanite with limited knowledge of the rural population and lifestyles paved the path to gain new experiences during the course of the research.

In the case of the domestic maids, my former acquaintance with some of the members of the maids' community provided me with an easier entry in the crucial initial stages (for example in the recruitment for interviews). I was a familiar figure in their circle of acquaintances. Some of them knew me from my childhood and had got used to my incessant questioning about their villages, their families and their lives. They in turn asked me to tell them about matters which were beyond their realm of knowledge. On some occasions their queries would dwell upon any interesting news item that I might have read in the newspapers. On others, they would enquire about any medication that I might know for an ailment that they were suffering from. They felt that as I had obtained degrees from a University, I was in a position to answer their questions. Later on, when I had joined a school, as a teacher, in the south 24 Paraganas district, they had often come 
to me to ask for sample copies of school books for their children. However there were also many participants in the research whom I knew only vaguely or not at all.

Neither of these groups could fully understand at first how their lives could be a part of any academic research. This is perhaps a reflection of the lack of interest that this section of the population generates among field workers and academics. Even though I had stated the purpose and nature of my research, repeatedly, at the beginning of interviews, acceptance was slow to follow. A few of them thought aloud that probably my work was similar in nature to that of government agents. When I questioned them about why they thought so, I was told that when general elections were due, different political party candidates (apprehended as government agents by common people) would appear outside their doorstep to ask about their concerns, and after promising redress in exchange for their votes, would disappear until the next election was due. I was therefore politely told that they had very low expectations of any benefits, either in the long or short term, which would emanate from my research.

My position as an urban educated woman had also blinded me to some of the interesting adjustments that these women make in their lives. I often noticed that during the interviews the maids glanced at the clock to make sure that they would not be late for their next domestic arrangement. When I commented how they could read the clock when they had admitted at the beginning of the interview that they had received no education, they pointed out that since time management was crucial their daily routine, they were familiar with the English numerals and how the position of the hands on the clock signified the time of the day. 
Secondly I often found myself as the subject of their sympathy because I had remained childless even after many years of marriage. My friends among the maids often wondered with all innocence, how empty my life was without children and how my husband and I should not allow more time to pass before starting a family. When I tried to analyze such reactions, I realized that motherhood was one of the most significant roles of their lives as often the status of a woman improved in her married family on attaining motherhood (Fruzzetti 1982:131). On one occasion I was 'sternly' told by an elderly maid that if I did not find enough time in my busy schedule to look after a child (which she assumed was a characteristic of an urban woman like me), she would be happy to look after the child on my behalf.

Thirdly, when I had first sought permission to visit one of the maids at her residence so that I could develop a better understanding of their lifestyle through participant observation, I was given directions that seemed so vague to me that I seriously doubted whether I could ever make it to her doorway (the directions were littered with first name references like, "you step down from the van-rickshaw and ask for Panchu's house" or "after you passed the banyan tree..."). However my doubts were laid to rest when I found that most of the villagers knew others by their first names and could easily direct me to my destination. I now understood the surprise of the maids, when they found out that I did not know the members of my own neighbourhood. The low social contacts with my urban neighbours were a contrast to the close relationships that developed in their rural settings. I also realized that my urban concept of directions based on road crossings or other artificial/man-made landmarks could not be replicated in a rural area 
where such infrastructure simply did not exist. Instead directions were based on personal human connections or significant natural objects which could not be duplicated in a city.

\subsubsection{Subjectivity}

Another important tenet of feminism has been to question the veracity of the concept of knowledge as "external, immutable, universal, just waiting to be discovered"(Jhappan 1996:19). The role of the researcher is that of an objective, neutral, passive observer whose emotions and credentials remain detached from his/her actions (ibid). Social scientists as individuals are as much a product of a complex multitude of forces as the social phenomena they study. As part of that society, they cannot claim independence from it (Flax 1990:219). It is equally true that he/she is in possession of a unique internal world that has been shaped through personal experiences and perceptions which are also recognized in others (ibid). The position of the researcher is an outcome of the politico-historical space occupied as much as the choices and struggles, of which he/she is a part.

Feminist theorists therefore have a profound influence in bringing the subjectivity at work during the research process within the purview of the research. This has also become an important defining point of the relationship between the researcher and the researched. The adoption of such an approach has a positive effect upon the whole process as Narayan opines,

It enables one to see with humility, and gratitude and pain, how much one has been shaped by one's context, to sense both the extent and boundaries of one's vision, to see how circumstances can circumscribe as well as inspire and to become self aware to some extent of one's perspective on things (1997:3). 
It is an invitation to the researcher to undertake a psychoanalytic journey of his/her own and question the causes behind the actions taken, words spoken and thoughts thought in the context of the research. Subjectivity is therefore an important lens to inspect the motivations and desires that have inspired the research.

My involvement with my research subject predates the actual research process by many years. I experience an admixture of pain and guilt when I delve into my past to retrieve those threads of incidents which have left their inalienable marks on my memory. As indicated earlier, I grew up in a middle class family of Kolkata surrounded by friends and relatives. Most of these families employed domestic maids to help out with the housework. As many of us had working parents, domestic maids were an integral part of the lives of the younger members of our immediate and extended family. I had grown up hearing comments such as, "Their maid is very good. They can even make her arrange beds now, even though she did not do it before," or "I will get rid of this maid the next time she takes another unannounced holiday." Initially with my inadequate experience, I saw nothing strange in these remarks. I saw the maids as disembodied selves whose task was to serve the employers. Another reason which I suspect contributed to this narrow view was that our parents divided the extra work among us on days when our maid did not turn up.

However as I grew up, I was fortunate in gaining a friend in a maid who had come to work at our residence nearly fifteen years earlier and had stayed on ever since. As my friendship with her and her friends grew, my perspective underwent a change. I could see that they were all part of their own families, with their own responsibilities and duties. They worked hard for long hours and traveled miles on public vehicles and on 
foot as they ran around from house to house in the neighbourhood, whether in the scorching heat, punishing monsoons or chilling winters. I remember that when my parents were not around, I helped my friend by asking her to skip a task and go home early (which I would finish up later) or by joining her in her various tasks so that she would finish faster. My cousins, who were witnesses to these little manipulations, called me a sentimental fool. All these activities however were a part of my youth and were largely ignored by the adults. As I grew older I became more vocal in expressing my support for the domestic workers (which took many of my relatives, who were employers, by surprise) especially when they blamed the maids for anything that went missing from their homes. Nevertheless I often felt helpless due to my limited ability to bring about change in the profile of this profession and was quite distressed and angry with this state. I also felt guilty at not doing enough. I felt that I was no better than the other employers who treated their maids as a means to an end (the end being a cheap and easy means of achieving a comfortable, less rigorous work day).

I sometimes felt that this research subject chose me rather than the other way around. I have taken up this research in order to involve myself and other like-minded individuals in the movement (which I happily report has already started) among the domestic workers to gain justified benefits for their work. This research therefore has been a tribute to the undaunted spirit of these women who hope to earn the dignity of their labour. 


\subsubsection{Power in the research process}

Power often makes its presence felt in interactions between unequal participants and consideration needs to be given to the question of who possesses power in the context of research. As pointed out by Edwards and Mauthner (2002:18) research is political rather than neutral. With questions raised, answers sought, privacy diminished, policies influenced, the research process involves power not only when it is performed but long after it has ended. Feminist scholars have acknowledged the intense interaction between power and academic knowledge that is set to occur during the research process (Rose 1997:307). The researcher by virtue of his/her academic standing is in a superior position to direct the proceedings.

During my research, I became aware that my image of a researcher, equipped as I was with questionnaires, consent forms and a tape recorder, had a significant impact on some of the interviewees. Three employers who agreed to be interviewed specifically allotted me a time slot when other members of their families would be present. All three had a daughter present when the interview was conducted. This reaction on the part of the employers made me aware of the fact that they felt at a certain disadvantage and were insecure in my presence. None of them had known me before the interview. All three of them were older than me and were members of Kolkata's middle class. They had known the purpose of the interview and had a general idea of what topics would be discussed. However, despite this they felt a certain lack of confidence in my presence. I felt that the cause of their unease might be attributed to two factors. Firstly it was our first meeting

and secondly they were apprehensive as to whether they could make a researcher 
belonging to a foreign university (the social condition of which they were only vaguely familiar with), understand their point of view.

When I became aware of this situation, I tried to establish a rapport with my interviewees by adopting different measures. I explained in detail the purpose of the interview and how it fitted into my whole research project. I reiterated the rights that they had as interviewees (for example, to refuse to answer any question or withdraw at any stage). I was also aware that I had to distance myself from my image of a researcher attached to a foreign university. Here I emphasized my identity as a local member of the community, being born and residing in Kolkata until very recently and being of a similar background. I also made a conscious effort to project the impression that I did not see anything wrong in the behaviours that they were describing. This is perhaps what is called 'role play' by Duncombe and Jessop (2002:119), which is demonstrating a somewhat false sense of friendship, based on the interviewer's perception of the role that would be most useful. I learned that these were the suitable reactions as I gradually felt the interviewees relax as answers grew lengthy and on many occasions they volunteered information that was complementary to the answers provided by them.

On the occasions when I was interviewing maids, I was faced with a different type of dilemma. As in the case of employers, only those maids were interviewed who had expressed an interest in participating after learning about the general outline of the research project from fellow members of the community. At the beginning of the interview sessions, apart from introducing myself to those I did not know before the interview, I also tape recorded some of our preliminary conversations and played the tape before the interview began. I started practicing this after the first domestic maid I 
interviewed, commented that she was not familiar with how it worked as she did not possess one. I went through this demonstration in all those cases where the interviewees claimed that they were unaccustomed with the instrument. Once this activity was accomplished I sought permission for a second time to go ahead with the interview. In one case an interviewee turned angrily on me at such a juncture to say, "Why should I be afraid of this (the tape recorder)? I am not making up stories." I felt I had unknowingly hurt her as she viewed my seeking of permission as a doubt of her honesty. I therefore quickly apologized and was careful from then on to recognize the sincerity of the interviewees towards their participation in the project.

However, my suggestion is not that the location of power remains fixed within the research situation. As noted by Rose (1997:313), power becomes a part of the negotiation between participants with unequal knowledge. Cotterill (1992:599) also observes that there is an inherent imbalance of power experienced during research. During the interviews with the maids, I felt that the interviewees had difficulty categorizing me because of my friendship with some members of the community. I was sometimes looked on as a friend, sometimes as an employer and sometimes a researcher, with the boundaries not always rigid. At times, in answer to a question, the interviewees would narrate stories. After some confusion at first, I began to realize that these stories had a moral which I was supposed to grasp as an answer to the question I had asked (for example the indictment of the rich person in the story, who loses his moral superiority by failing to show compassion or benevolence to the poor and the needy, carries a lesson for the employer class, of which I was one). By relating the story, the interviewee had delivered a veiled criticism of me, the interviewer, who she also considered as a friend 
and an academic researcher, and therefore was in difficulty to rebuke directly. This was also an example of resistance to authority and the maids' constant efforts to test the limits of power.

\subsection{The Research Process}

While making preparations for my field visit to Kolkata, a perusal of literature (for example Villarreal 1992) made me aware of the inevitable uncertainties and chaotic nature of research. The participants of research are social actors who manipulate and adjust the research process in unexpected ways, altering the course of the research and their own location in it. The sharing of everyday life experiences, the interpretation of meanings attached to such actions at an individual and collective level and the consequences that are generated, needed to be incorporated in research planning in all of its complexities (ibid:248). The research that I undertook provided me an opportunity to experience the dynamics of these interactions.

\subsubsection{The research location and participant selection}

My association with the research area as indicated previously, date back to my childhood. The research was however conducted over a period of eleven weeks lasting from the last week of April 2005 to the middle of July 2005. During the preparatory phase (based in Ottawa), I reviewed the literature to gain knowledge about the different relevant theories and concepts and prior studies and research work that dealt with this topic. I also tried to establish links with academics from universities located in Kolkata whose research interests included workers in the informal sector of India. I received responses from two academics, Dr. Ajitava Roychowdhury from the Jadavpur University 
and Dr. Ishita Mukhopadhyay from Calcutta University. A third academic Dr. Nirmala Banerjee was contacted while on field. I had also tried to establish connections with Kolkata based NGOs working in this area but received no response at this stage.

While considering the location for my research I was aware that two types of locations had to be included. The first had to be an urban area (south Kolkata was chosen) to which the maids traveled to reach their place of work. The second had to be located in a rural area the (district of South 24 Parganas was chosen) where the maids resided. The choice of south Kolkata (Map 4.1) was prompted by the fact that this area of the city had been settled at a comparatively later stage than the rest of the city and had more planned middle and high income residential neighbourhoods. Middle class families in this area usually employ domestic maids commuting from the surrounding peri-urban areas in contrast to similar households in central and north Kolkata that employ local maids residing in adjoining slums. The southern part of the city is better linked to the rural southern districts by local train services which make commuting on a daily basis possible. My familiarity with this area as well as with the population of maids and employers had also been important considerations. Within the South 24 Parganas district, the two chosen rural sites were located close to the rail routes of Canning and Baruipur (Map 4.2) from which a large number of women journey to south Kolkata to work as domestic maids.

On arrival at the field, the first few weeks were spent re-establishing my links with friends of the maids' community. I provided them with a brief oral synopsis of the research objectives and sought their cooperation in disseminating the information among other members of the community. They agreed to introduce me to other domestic maids 


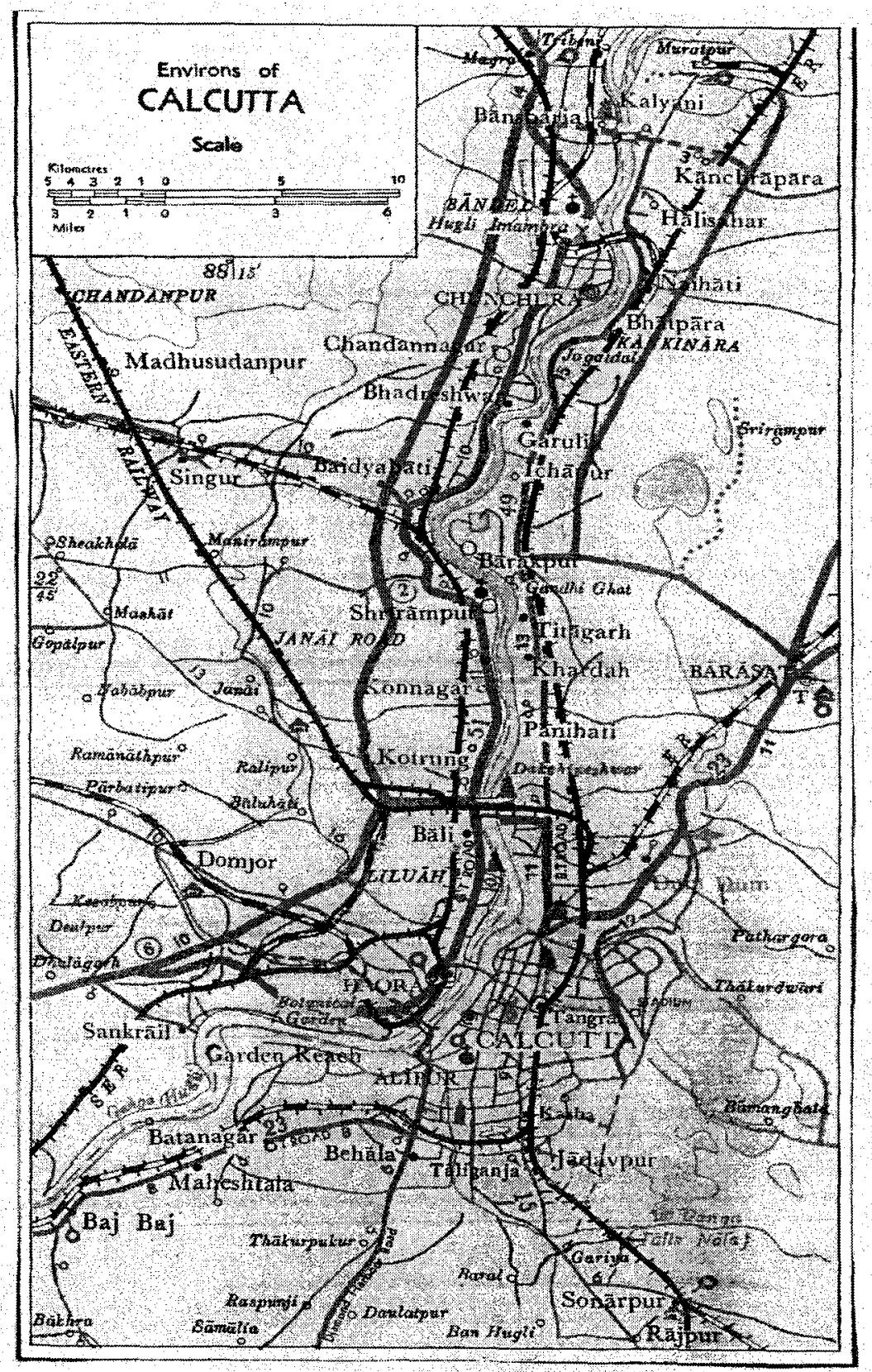

Map 4.1 - Research Area location: Calcutta Source: Survey of India 


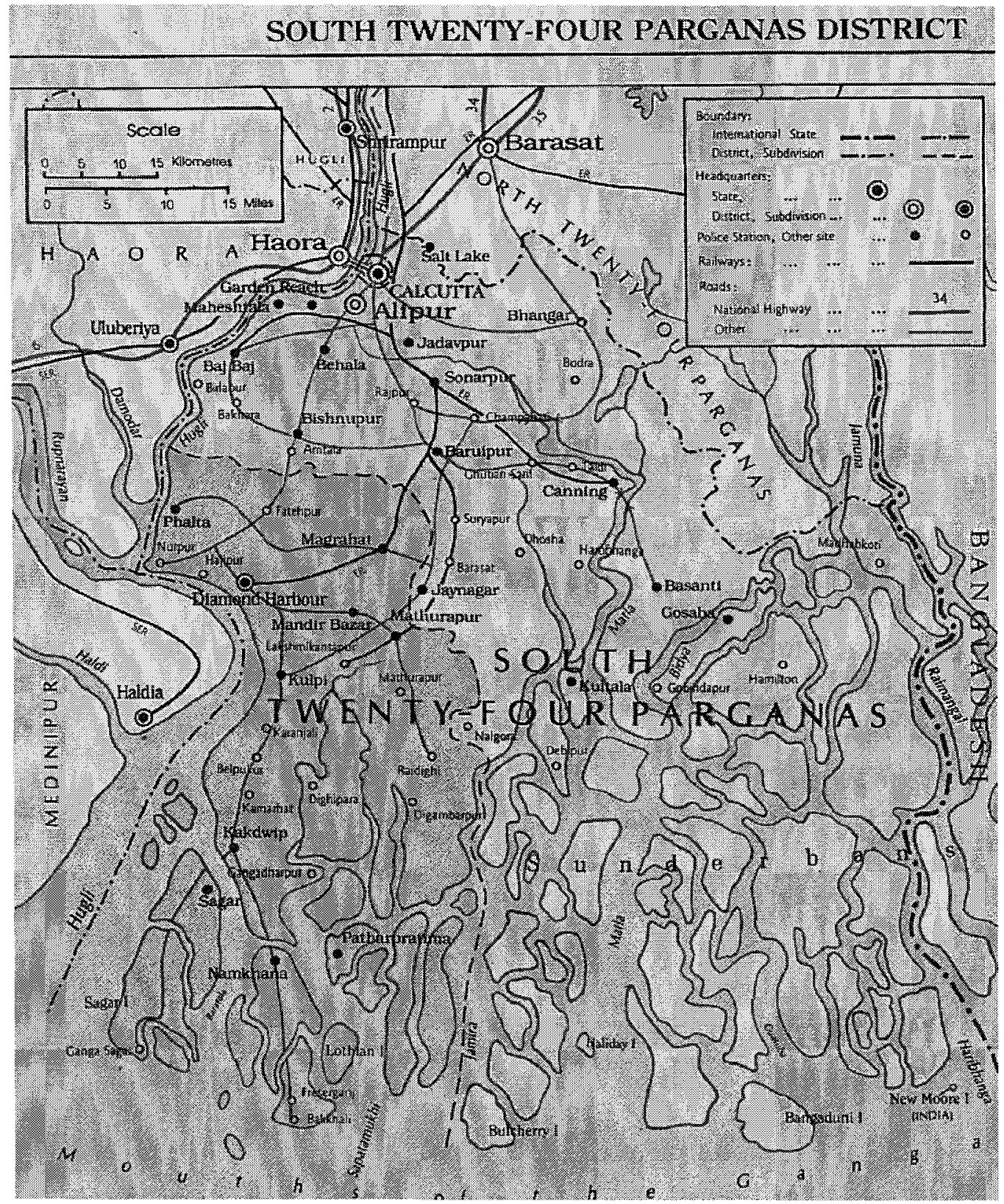

Map 4.2 - Research Area Location: South 24 Parganas Source: University of Texas at Austin 
who expressed an interest in participating in the research. The employers were similarly contacted by using personal links via a snowball method. About twenty domestic maids and ten employers were selected to participate in the interviews. Each was shielded from identification in the text through repeatedly changed pseudonyms.

The maids who participated in the interviews were chosen on the criteria that they commuted daily to the city from rural settlements stretching along the railway lines which connected the city with the peri-urban areas of the South 24 Parganas district, including Canning, Mathurapur and Diamond Harbour (Map-4.2). Among the maids, efforts were also made to capture their heterogeneity as evidenced in marital status (married, widowed and deserted), age (young and old), religion (Hindus and Muslims), family composition (age of children, extended family support) and employment status of spouses (employed, semi-employed and unemployed). Amongst the employers the differences that were recorded were age, employment status, income level and family size and composition.

\subsubsection{Semi structured interviews}

During the first five weeks of the research, I carried out semi structured interviews with domestic maids and employers. My choice of semi structured interviewing as a method was prompted by the fact that it provided an excellent opportunity for the researched to voice their concerns and also because, through it, deeper familiarity/relationships with the parties involved could be forged. When conducted with sensitivity, both the researcher and the researched are able to use the interviews as a means of critical self introspection. 
I conducted the interviews with the maids and with female employers who were recruited from a different locality from where the maids served to protect the anonymity of both parties. Primary responsibility for the domestic sphere affected both groups because they were women, who otherwise belonged to separate classes, educational status and income categories. Through the interview process I explored how these women viewed domestic work and how they contributed to the construction of its value. The interviews were all tape recorded.

At first, I had planned a number of interview sessions with each of the maids as I thought that they would not be able to spare more than half an hour for a particular interview session because of their very busy schedules. However when I discussed this plan with my potential interviewees, I had to revise it. The research was conducted during very hot weather with the temperature often climbing to over forty degrees Celsius. Under such intense heat, the maids faced a great deal of discomfort while traveling on foot from house to house. In such a circumstance they thought it best that I should confine myself to one interview even if it meant a single larger slot of time. This arrangement would save the maids having to pay multiple visits in order to complete the interview. They thought that it was the best approach even if it meant that they would be late in reaching their residences on that day. When I realized the logic of their argument and saw a consensus emerge on this issue, I decided to adopt it. The use of semi structured interviews also suited this arrangement as the individual interview could not last beyond one and one-and-a-half hour given the time constraints faced by the maids. The questionnaires used for this purpose (Appendix-B) acted as a very useful guide for me so that I could productively use every minute of the interview session. At the same 
time the interviewee was often encouraged to pause, reflect, elaborate or direct the interview in any direction of their choice. The collection of oral histories or personal narratives which were the other research method I had considered would have required a much larger allocation of time by the maids, which they could ill afford.

The interviews with the maids were conducted mainly in the afternoon after they had completed the first round of visits to the houses they served and therefore took some time off before they would begin their second round of visits. However some maids preferred to be interviewed after they had finished all of their work, just before running to catch their trains back home. The interviews with the maids were all conducted in an unoccupied apartment (owned by me, lying vacant currently as I have moved to Canada). Other alternate locations were impractical (the maids' residences were spread out over the vast southern peripheries of Kolkata) or too public (like roads or employer's residences) for those maids who needed privacy to be interviewed. The employers were all interviewed at their respective residences at a time of their choosing. All of the interviews took place during the first five weeks, thereby allowing me to collect and question the ideas and actions of each of the groups from the perspective of the other. The interviews with the academics were conducted later on at their offices. I used these occasions specifically to gain insights about the roles that the society, economy and the state have played or ignored to play, which have resulted in the marginalization of the maids.

\subsubsection{Participant observation}

I used participant observation as a research method to complement the interviews. These were carried out at the residences of the maids in the rural areas. As the 
maids spent a large part of each day working in the cities, I could only be a part of their family and community life when they took a holiday from work. I undertook these visits in the second five weeks of my research, by which time I had developed a wide network of acquaintances among the maids through interview sessions and through my involvement with two NGOs who worked with members of this community.

I went for such visits on three occasions. Each visit enriched me with its own unique lessons. On the first occasion the maid who had invited me to visit her residence, did not turn up at the designated time and place. I was a bit puzzled and frustrated by this but as I did not meet her for the next few days I could not enquire about it. So when I received an invitation from another maid, I was a bit apprehensive because of my prior experience. Therefore I was not so surprised when I was later approached by my proposed host who reported having second thoughts about the whole idea. I felt a crisis of confidence at hearing this and asked her what had happened. It then became clear to me that when the maid had discussed the plans with her family members, they had discouraged her as they felt self conscious about their poverty being exposed to a city bred researcher. I suspected that this could also be the reason why my appointment with the first maid had not materialized. I knew that the distance of class and status between my host and me was not something I could wish away but I made every effort to convince her that my visit was not to 'study' their poverty but to gain a first hand experience of their family bonds, social networks and coping strategies. I was probably able to convince her of my sincerity for the visit went through and I followed it with two more visits to the homes of other maids. 
For this I had to make two 'concessions'. On the first instance I was rebuked, good-naturedly, for not wearing the signs of a married woman (the vermillion mark in the parting of the hair, a dot on the forehead and a lining of a red dye on the edges of the feet - traditional symbols, for married Hindu women in eastern India). So I had to give in amicably when my friends in a group took it upon themselves to remedy the situation. Secondly I also had to give up the notion of being able to help my host and her family in their daily chores so that I would not impose my presence on their work routines. As my visits were few in number, I could not shed off my image of a 'guest' who according to the local social customs, is not supposed to be engaged in the family's chores. ${ }^{1}$ I felt however that these visits did provide me with a chance to close the gap between the abstract and the experienced worlds of the maids and empathize with their reality in a way which the interviews alone would not have provided.

\subsubsection{Action oriented research}

I was keen to pursue this method of research because I felt that it would provide me with a link between theoretical knowledge and practical experience which could enhance the development of better scholarship informed by ideas of social justice. (Kobayashi 2001:63). It is a way of deploying feminist research to support and participate in a social movement aimed to dismantle structures which perpetuate the oppression of women. With this aim in mind I had tried to establish contact with and offer my services to NGOs that were located in Kolkata and worked with women in the domestic work sector. I felt I could benefit immensely from the experience of investigating practical

\footnotetext{
1 The belief is that the more you serve the needs of guests, the more blessings will be showered on you, as the guests are considered to be on a par with deities.
} 
methods and obstacles that these movements face. Through a library ${ }^{1}$ search I became aware of the activities of an NGO called Parichiti. ${ }^{2}$ Its activities, aimed at organizing the domestic workers, motivated me to join them as a temporary field worker.

I was associated with this NGO for five weeks. At the outset, the senior members of the NGO stipulated the terms and conditions of my participation in the association's activities. While they allowed me to be a part of their weekly visits to the railway stations to organize meetings with the maids, I could not be a part of their office work and internal deliberations. It was also agreed that at the end of this association I should provide Parichiti with a report of findings gathered while working with the organization and suggestions to improve its operation. This document is attached as Appendix-C. I was also disallowed from using a tape recorder or a camera while working for the organization. They perceived that these recording devices might be viewed with suspicion by the maids as the recordings could be used later as evidence against them. I therefore relied on my memory to record at the end of the day, my experiences from these instances, in my research journal. Once these issues were ironed out, I became a part of their field work team. During the next five weeks, my association with the maids who joined the meetings at the stations grew to one of acceptance and trust. I also accompanied the members of Parichiti as they opened up investigations and followed up cases of physical or mental abuse of maids and tried to get redress on their behalf.

I was also sent by Parichiti on behalf of their organization to investigate the cause of the cancellation of a cheap monthly ticket (priced at Rs. 15) provided specially

\footnotetext{
1 I received a lot of help and assistance from the staff of two local libraries (The Centre for Studies in Social Sciences, Calcutta and the National Library, Calcutta) where I collected a lot of reference material in the form of books, journals, published papers and newspapers.

${ }^{2}$ I hereby came upon a reference to an NGO called Sachetana which was at the time working towards training of women panchayat members in West Bengal in budgeting government finances with sensitivity towards gender issues. The staff of this NGO introduced me to the work of Parichiti and provided me with contact details.
} 
for workers who worked in the unorganized sector. This ticket, provided by the Ministry of Railways, Government of India, (in 2000), was supposedly discontinued when a different incumbent took over the post. From my investigations and discussions with the railway officials, I found that this ticket had not been withdrawn but that it applied now only to workers having an income of Rs. 400 or below (that is for population below the poverty line ${ }^{1}$ ). Despite being workers of the unorganized sector, the domestic maids did not qualify as most of them had incomes above Rs. 400 per month. When I questioned the officials as to the reasons behind this decision, I was informed that the orders had come from the upper levels of the official hierarchy. This experience made it apparent to us at Parichiti, how an official machinery unresponsive to the needs of the workers in this sector, could easily reverse positive changes in the favour of the workers once the political atmosphere permitted them to do so. I presented my findings to Parichiti and it is their intention to take steps to challenge such arbitrary government measures on behalf of the domestic maids.

The other NGO that I became associated with is called Nishtha. This NGO works towards the empowerment of women among sixty villages in the Baruipur area. Although I did not formally join this organization I was allowed to interview various officials, carry out group discussions with domestic workers who were members of its women's groups, and members who had been elected to the local panchayat (village level governing body). Nishtha has been able to create avenues for alternate means to generate income for its members and provide opportunities for growth of educational and other professional skills among them. This NGO has been able to bring about significant

\footnotetext{
${ }^{1}$ Poverty line (1999-2000) is the per capita monthly income of Rs. 350.17 in rural areas of West Bengal and Rs. 409.22 in the urban areas of West Bengal (Sharma 2004b: 9)
} 
improvements in the social and economic life of its members. My association with both these organizations has continued beyond the life of this particular research project.

\section{3 $\underline{\text { Reflexivity }}$}

In reiterating the importance of reflexivity, Bassett explains it as the "practice of reflecting upon and questioning the assumptions and statements of one's own research" (Bassett 1995, cited in Hoggart et al. 2002:46). After returning from the field and going through the transcripts and analyzing them, I have had moments of self doubt as to whether my research has been able to do any justice to the subject that I deal with and whether I am creating mere generalizations where there were none. I cannot claim to be free of these doubts even at present. I have defined this project on the basis of the concepts, theories and relevant methodologies and invite the members of the audience to make their individual interpretations. I have widely used the first person narrative in the text to lay the groundwork for the analysis that follows. I have attempted to provide an account of the often conflicting and complex relation between myself (the researcher) and the researched (the maids and employers). I have also indicated the politics of my subjectivity. For this I have recalled incidents from my memory and instances that were recorded in my research journal. The chapters that follow are the products of the findings of my research. In representing the subjects, however, I accept the responsibility for the 'little' lost stories that result from transcribing lived lives. 


\section{Chapter -5}

\section{The Bridges that Separate : Employers' Attitude towards Domestic Workers}

To define feminism purely in gendered terms assumes that our consciousness of being "women" has nothing to do with race, class, nation or sexuality, just with gender. But no one 'becomes a woman'...purely because she is female. Ideologies of womanhood have as much to do with class and race as they have to do with sex (Mohanty 1991:12).

A continuous process of urbanization and expansion has come to mark the growth of Indian cities during the twentieth century. This process has been accompanied by the creation of a plethora of new occupations, transformations of existing ones and the obliteration of some older ones. Not only has the population which lives within the geographical area of the city been affected but so too have those who live outside the city boundaries, through economic, social or political ties. Domestic service is one such occupation as demand for this service has grown among the upper middle and middle classes of Indian cities.

Kolkata's growth as the most prominent metropolis in eastern India has created space for the growth of this service, which has been provided by a variety of workers: those migrating from rural areas and settling in its growing slums, those who live fulltime in the homes of employers and only occasionally visit their village of origin, or those part-timers who live in the peri-urban areas and commute to the city everyday. An overwhelming majority of domestic workers are women ${ }^{1}$. The workers in this sector who commute to work everyday use the suburban rail links and find employment in the areas lying close to the railway station so that they can traverse the distance from the railway station to their employers' houses on foot. They work as part time workers in a number of

\footnotetext{
${ }^{1}$ According to figures available for 1998-99 approximately $4.5 \%$ of males and $35.7 \%$ of females were engaged in this occupation in Kolkata (Mohanty and Ram, 2004:9). The percentage of minors in this population of domestic workers has not been explicitly mentioned by the authors.
} 
houses, visiting each one once, twice and sometimes thrice during their daily work routine, before making their way back to their residences.

The middle class houses which employ these commuting workers for domestic service, have themselves undergone changes, some of which have led to the preference for part-time workers. Nuclear families have replaced joint families and home spaces have shrunk due to the high premium placed on urban land. This trend has restricted the amount of space available and employing part-time domestic workers instead of full-time workers (who were more commonly employed before), is a better solution to manage reduced living spaces.

The member of the household who traditionally coordinates the work of the maids and is directly involved in deciding the terms and conditions of service is generally a female. The only exceptions occur in cases where there is no adult female in the house. The general practice and acceptance of this arrangement probably stems from the perception of females being responsible for domestic work. My attempts to seek employers from either sex for interviews were thwarted as a result of this practice. Male employers directed me to the female members of their household whose gendered identities supposedly qualified them to better participate in such a research subject. Female employers agreed to this role.

This aspect of my research, where I deal with female employers' interactions with the maids as perceived by the employers, is an area where published research is scarce. My interactions with the employers provide a glimpse into their relationship with the maids, as female employers adapt themselves in their multiple roles, such as being representative of the middle class or the most likely candidate to cope with all the 
delegated duties of the domestic maid in her absence. In such circumstances I argue that the women employers remain as much implicated as the male members in exploiting the cheap labour of the maid. By perpetuating the image of the maid as 'militant', 'disloyal', 'dishonest' and as 'mere assistants', middle class woman are contributing to the continuing differentiation and denigration of women from the lower classes.

The purpose of this chapter is to further establish the context within which the maids find employment. The context here is narrowed down from the economy and the state to the employer's home which produces the immediate site of work for the domestic maids of Kolkata. This chapter has been divided into three sections. In the first section I look at the factors within the middle class household that generate needs for employing an external domestic worker and specifically a female domestic worker. In the concluding part of this subsection I look at the reasons why employers prefer manual labour to automated gadgets and appliances available in the market (which are often thought of as potential replacements for housework done manually). In the second section I investigate two areas of change that have added a new dimension to the employeremployee relation in this profession. One relates to the loss of devotion on the part of the maids as perceived by the employers when compared to the workers of the past. The second change is the novel presence in this labour market of maids from the Muslim community, which has resulted in greater competition among the maids where religion rather than caste divisions are taking precedence. In the third section, I look at the employer's construction of the maid as the 'morally deviant' woman who is undeserving of the compassion of the middle class, thereby exonerating the middle class in its own eyes from becoming responsible for their wellbeing. 


\subsection{The Preference for Females}

Employers' preference for females is widespread, leading to a feminization of this occupation. The gradual transition of this vocation to one that is increasingly done by females can be linked to both urbanization and modernization. One element has been the greater visibility of women in the public life. Women can now, in the course of their daily activities in the household or in their profession, use public facilities like roads, transport systems, markets or other public spaces. This change has reduced the need to engage male domestic helpers who previously assisted the females of the house by buying provisions from markets and shops (Banerjee 2004:64). As some older employers recalled, as children they had not seen older women of their families leave the house premises except under special conditions and with elaborate prior arrangements.

Also, as joint families break down into nuclear ones, the number of family members under the same roof shrinks. Female family members have lost the security of the company of other family members which has left many of them feeling vulnerable in the company of outsiders especially if they are male. Female domestic workers are preferred because they are perceived to be weak, pliable and less dangerous than men. The perception of threat from male outsiders within the inner confines of the home has been heightened by recent cases of theft, burglary and murder by male domestic workers as highlighted in the news dailies of Kolkata (Anandabazar Patrika, Sep.16, 2004; The Statesman, May 5, 2005). The preference for females in this job therefore grows as a result of a reaction to this negative image of the male domestic help.

Lastly, the tasks involved in domestic work are typically those with which women have traditionally been associated, irrespective of class. Even during the time when more 
men were employed in this job, they were mainly responsible for outdoor activities such as shopping, tending gardens, looking after domestic animals and the like. Women's affiliation with this job is due to the perception of it being an extension of the work that they do 'naturally' in their own households (Raghuram and Momsen 1993:56). Many employers expressed discomfort in imagining a male domestic worker doing the same tasks that they would easily ask a woman to do. The deep roots of the social norms that demarcate the boundaries of the sexual division of labour have resisted responding to the changes brought about by time. This is further borne by the fact that when the maids took leave from work, most of the female employers reported that they had to either cope with all the work on their own or finished it with peripheral help from some family members. The struggle, in recent times, between traditional eastern norms and a more modern liberal perception based on equality has resulted in a grudging acceptance of the fact that male members should share in domestic responsibilities. This however is still viewed as the negative influence of an alien culture in many households. Many of the female employers reported that without help from the maids they could not continue for more than one week at a stretch. The maids and their female employers both shared the common platform of a gendered identity which tied them to persistent ideologies about their particular capacities and capabilities. Thus the perceived greater compatibility and efficiency of women in this job has contributed to their concentration in this occupation.

\subsubsection{The necessity of engaging maids}

The rationality, morality and efficacy of engaging external help for tasks which are essentially viewed as part of the duties of women in the household, has been and 
continues to be, a cause of unease among the Bengali middle class. The question of employing servants in middle class urban families had cropped up during the era of the Nationalist Movement, which was trying to establish a competing discourse that attempted to distance itself from the hegemonic discourses of its western colonial ruler. This issue acted as a supplementary argument to the main question of establishing a distinct Indian middle class womanhood in opposition to the westernized women who was viewed as lazy and employed others for tasks that they themselves needed to perform (Chatterjee 1989:240). The criteria of employing servants were therefore used to distinguish between the 'modern' woman and their frugal, diligent and traditional counterparts (Banerjee 2004:112). Within the contemporary terrain of middle class households of twenty first century Kolkata, a similar ambivalent mood on the question of engaging domestic servants continues in subtle ways.

The present trend of engaging domestic workers is due to the low wage rates commanded by workers of this sector and their easy availability, as discussed previously. Another contributing factor has been the growing propensity for middle class women to gain employment or participate in activities outside their homes due to their rising educational achievements (Banerjee 2002:58). However, as pointed out by Ramu (1989:94), the sexual division of labour inside the Indian household still remains largely intact, with males retaining their exemption from domestic tasks. The females have been unable to seriously challenge this arrangement because of the widespread social acceptance of 'interlinks' between femaleness and ease of carrying out familial responsibilities. Thus they have come under increasing pressure to establish an alternative arrangement in order to fulfill their multiple roles. The supply of displaced female labour 
from the suburbs has helped to feed this need. As a young employer Anima, puts it rather succinctly,

I have to send my children to school, I have to look after their studies, I have to cook the food and I have to give music lessons. I do not think I can cope with all this at the same time without the help of my maid.

This serves as an instance of how an employer's perception of her abilities to fulfill her domestic and professional responsibilities depends on ensuring a source of external help.

Another commonly mentioned reason had to do with external factors like climate and the particular nature of Indian cooking which is thought to be time consuming and at odds with other activities. As another elderly employer Nandini comments,

I think it is a necessity. In our Indian households we need to do certain tasks everyday. For example we sweep and mop the floor everyday because the pollution is high and we have a hot and humid tropical climate and so we have to keep everything clean. Again our cooking system is quite elaborate and we need to spend a considerable time behind it. This is the reason why I keep a maid to help me out.

Nandini provides a different set of reasons from the other employers as her circumstances are slightly different. Since the demise of her husband she lives alone. Her grown up children have left home to settle in other cities. She is a social activist who is often busy and is engaged outside her home. She therefore accepts the help of a domestic worker in order to maintain her personal standard of a clean environment to live in and have food prepared in a traditional manner. Both these tasks require considerable expenditure of time, effort and energy. The services rendered by the maid therefore allow her to maintain her personal well-being. It also gives her a chance to pursue a more socially recognized role of an activist.

Again, when tasks like mopping or sweeping the floor or washing of clothes or scrubbing utensils (three of the most commonly performed tasks of the maids) are done manually, it generally requires squatting on floors and spending a considerable amount of 
time working with soap and water. These activities are considered tedious and physically rigourous when performed on a regular basis and therefore construed to be menial in nature. They are in dissonance with the socially accepted role of a bhadramahila (a middle class cultured and educated woman), an imagery cultivated during the Nationalist Movement. Many of the female employers expressed an indignation at the idea of having to perform these tasks in their households on a permanent basis. They had internalized the socially segregated roles of women belonging to different cultural and educational backgrounds and were not ready to consider other possibilities. In avoiding these tasks, they were creating a difference between themselves and the maids who needed to do this work in exchange for money. The lack of dignity attached to these tasks influenced the employers' decisions to avoid them if possible. It also explained the low status that was reserved by the society for workers belonging to this occupation.

While the above discussion provides the different reasons of the employers to engage maids, the thing to note is that they are careful to show that the tasks done by the maids are only 'complementary'. This is because cooking is considered to be the main domestic task which often the female employers reserve for themselves ${ }^{1}$. The importance of cooking is due to the fact that it is intimately related to the health of household members. Thus although domestic workers are engaged to help in the preparation of food, very few households employed a cook. It was also a task to which the stigma of menial job was not attached. Most female employers did the cooking themselves. The domestic workers who were mainly employed in tasks where they could not avoid contact with dirt and dust were generally not considered fit for the task of cooking. Some

\footnotetext{
1 This practice where the housewife remains responsible for the cooking even when domestics are employed by the family has continued from the colonial times (Banerjee 2004:65).
} 
of them reported their readiness to switch to this task as it commanded a greater salary. However they were unable to do so as the demand for cooks was low. The employers therefore used their continued engagement with cooking to retain their claim of ultimate responsibility for household tasks while the maids continued to be looked on as mere 'assistants' . Also the fact that the employers can cope on their own (albeit for forced short periods, as when the maid is on leave) prevents them from considering the maids as indispensable. Fellow employers who engaged cooks were criticized as by doing so they had forfeited their claim to the 'chief' domestic task. As one employer pointed out derisively, "Nowadays in many houses they are engaging a cook...even if there are two people in the house, they keep a cook and a part timer." Such employers were considered lazy and self indulgent, an image that has continued from earlier periods. Thus this constant relegation of the maids as subordinates, prevents them from asserting themselves as workers who can demand adequate compensation for their labour.

\subsubsection{Gadgets and appliances as failed alternatives}

Gadgets and appliances, gifts of modern technology, have been perceived as tools that will simplify housework and make it possible for the middle class woman to manage her time more efficiently. However within the urban middle class context of Kolkata, the introduction and use of automated appliances for domestic purposes (such as washing machines, vacuum cleaners, food processors) has not led to their widespread use. While some employers were amenable to the use of technology, most were not willing to make the transition from manual to technological methods to take care of the tasks that continued to be done by domestic workers in these households. It is generally expected 
that a certain amount of reluctance will be encountered when switching from a traditional method of doing a task to a newer technique (Bhoite 1987:32). To make the transition from reluctance to willingness, the users should not only benefit from this transition but also perceive themselves to be the beneficiaries of this transition. Many of the employers were doubtful as to the real benefits that they would receive from the use of gadgets. Some employers, despite possessing them still preferred the work of the maids. As one employer Shampita explains,

I think even if the gadgets are there, it is much more helpful to have the maids do the tasks. For example even though I have this washing machine, it is more cumbersome to use it always as I have to wipe it and dry it every time I use it. But when the same task is being performed by a maid she will herself immerse it in soap, wash it and hang it in the clothes line. When she comes for the second visit, she will collect the dry clothing and bring it back. Again I think that mopping of the floor is better done by us that is either the maid or myself.

In the account presented above it becomes clear that the preferred method for domestic work is manual. The advantages gained from the use of the gadgets are not considered to be compensation enough for the time spent in maintaining them. Also their performance is often thought to be less satisfactory than the gratification derived from performing the task manually. The gadgets are often found to be less suitable to the employers' personal preferences and tastes. For example many of them complained that food cooked with spices ground in a mixer-grinder tasted inferior to spices ground on traditional stone grinders, or how the dishwasher did not perform adequately to remove the oil and soot that cooking Bengali cuisine produced. These dissatisfactions prevented the employers from incorporating appliances more fully into their daily housework.

A second factor that has also contributed to a continuing trend of employing maids has been the high price of these gadgets. As Bhoite (1987:32) points out, the labour saving domestic gadgets are considered by the government to be luxury items and 
consequently are taxed heavily (for example the price of a washing machine ranges from Rs. 5500 to 8000 - approximately 100 - 250 Canadian dollars). For the middle class families with a lower income, it becomes difficult to afford these machines especially in homes where there is competition between goods for the kitchen and those for general entertainment like a television set (Ramu 1989:135). In such a situation many employers feel that it is cheaper and more convenient to use the services of domestic workers than it is to invest in domestic appliances.

Implicit in this explanation is also the consciousness of residing in a labour surplus economy. The pressure of excess labour pushes wages down. In the unorganized sector, where there are no guarantees of a minimum wage, the free play of market forces results in a wage rate that is easily affordable by the middle class. The middle class therefore regards employing domestic workers as a better return on their investment of time and money than using gadgets and appliances.

Last but not least, an important consideration for the employers is also the fact that they do not want to be perceived as avoiding their domestic chores as documented by Ramu (1989:135). In his study of dual and single earning couples in urban India, he noticed the caution exercised by wives not to project the image of being 'lazy' and 'neglectful' by showing excessive dependence on outside sources instead of their own labour. As a middle aged employer Amrita pointed out,

Today the fashion is for everybody to lead a leisurely life wearing good clothes and watching television and not working at all. They would not even take the trouble of switching on the machines. In fact many of the machines are useless. For example sometime ago there was a machine used to make ruti (Indian home made bread). It was said to a very easy process. I have not become that lazy yet. 
The employers are therefore afraid that their dependence on the machinery will cast an image of inefficiency and laziness. The help of the maids is therefore preferred, as it is easier to portray the maids as helpers under their direct supervision and guidance.

\subsection{Considerations for recruitment and retention}

In this section a study is made of the social and personal considerations that the employers identified as relevant to their strategies for recruiting and retaining domestic workers. As employers attempt to cast doubts over the integrity of the workers, they justify their immunity to the plight of the workers in this sector.

\subsubsection{Performance standards driven by nostalgia for the past}

Changes over time, such as the growing pressures of modern life which affect most members of society, although acknowledged by employers, were rejected as part of their rational analysis. Memories of their past shaped their expectations of the present to a great extent. The employers shared their fond memories of past domestic workers seen in childhood or remembered in stories heard in the past. The strongest impression left behind seemed to be one of sincerity. One employer, Purnima, recalled from memory the following incident to press her point.

I remember my parents employing one small boy who was so sincere in his duty that when we had a celebration scheduled for the next day and we asked him to report early, he came the next morning at the early hours of dawn and slept at our doorstep wrapped in his blanket.

Evidence of such sincerity lingered in their minds as traces of the 'ideal' that set the standard against which the present was measured. Another closely related characteristic 
that occupied an equally fond space in memory was the domestic worker's willingness to perform duties beyond designated tasks. As another employer Rama recollects, In previous times, I have seen that if she [maid] saw that the housewife was ill and could not get up, she would do some extra work to help her out. If you gave her something in return she would accept that gladly but will never demand that from you.

Implicit here is the employer's desire to perpetuate the unquestioned loyalty and services of the maids as evidenced in her past. This signifies the tussle between the employers and the working classes. While the middle class (personified by the employers) readily accepts the extra help of the workers in times of crisis, it is not prepared to guarantee a reciprocal arrangement when the maids are in trouble. The middle class dreads any loss of power brought on by the empowerment of the maids, which might offset this unequal relationship.

It is the increasing formalization of domestic work that has brought about certain changes in the nature of the contract that guides this service. This contract, although still unwritten as in the past, has formed a battleground over which the implications of rights and duties are fought. This has become a cause of concern for employers as the maids try to use it as protection against subsequent changes that the employer may attempt to impose on them. The contentious issues include but are not limited to: holidays, extra work and benefits. The maids have been able to drag these issues to the bargaining table as with time, the profile of the domestic worker has changed. The part-time nature of the job which has replaced the full-timers of the past means that the maid does not need to stay under the constant presence of the employer. She has multiple employers with individual service contracts. This gives her a basis for comparison and negotiation. She also comes into contact with other maids with whom she shares similar circumstances. 
This contact provides her a different platform to begin with and a different attitude than her predecessors. Her primary and immediate loyalty has changed from the employer's family to her own. This shift has brought about a rearrangement of her priorities which may not always be in favour of the employer.

To illustrate this point, I give the example of an employer who had revealed to me how it had become more difficult to recruit maids in her area than in the past. Her residence was in an area located quite near to the railway station where a large number of maids disembarked to work in the neighbourhood. When this was pointed out to her, she explained that this was precisely the reason why it had become difficult for her to recruit maids. The neighbourhood, because of its proximity to the railway station, attracted a large crowd of maids, many of whom were young in age and had a different attitude to work as compared to the older generations. They were not readily amenable to compromises on work standards compared to their elderly co-workers and used their network of friends and acquaintances to obtain background information about employers who had frequently changed maids on pretexts of unsuitability. This new development made the employer apprehensive about her prospects of recruiting maids in the future.

Such changes, whether real or imagined, have forced employers to readjust themselves to new conditions that have also prompted unease. As one middle aged employer Bulbul states,

Today the maids are more adamant. If you ask them to do a work, they would say 'I have other homes to attend to' and walk off.

The employers resent this loss of control and try to resist its decay. Thus qualities such as 'obedience', 'loyalty', 'sincerity' and 'sympathetic' were used to identify the maids of the past in contrast to those of the present. By failing to live up to the impression of the 
past maids, the present workers were seen to be less worthy of recognition and rewards than their predecessors.

\subsubsection{The importance of caste and/or religion}

Another interesting facet of paid domestic work in India in the past has been the job specialization/exclusivity that is related to the caste structure inherent in the Hindu society. The long standing hierarchical division of the Hindu society in India was based on a caste system that provided guidelines for social and religious intercourse among the castes and limited the selection of occupations that caste members could enter (Rath 1996:34). Searle-Chatterjee (1979, cited in Raghuram 2001:607) had pointed to a correlation between the caste of the domestic worker and the nature of the work done in traditional Indian society. The ayah was kept as the general helping hand, preparing food or helping in the kitchen was done by the cook, while the sweeper woman cleaned the bathrooms and disposed of household waste. These tasks were performed by women belonging to different castes and they received different levels of remuneration for them. Raghuram (2001:610) in the light of her research done in Nithari village, of Uttar Pradesh in 1989 , found that these divisions have collapsed and regrouped into two categories as the mai, who worked as a part timer and cleaned the house and washed the clothes, and the sweeper woman who was responsible for garbage clearance.

In urban Kolkata today and elsewhere in urban India, this scenario has not remained static. Changes include the growth in nuclear families and a greater propensity to employ part time live-out domestic workers as discussed earlier. Garbage collection has become a municipal responsibility, being organized on a community basis, relieving 
the individual household from making special provisions. Thus the tasks of washing and cleaning that generally are assigned to domestic workers have become more homogenized than ever before. However since most of the maids originated from the lower and poorer castes, a need was felt to investigate the link between caste divisions and women's access to this job market.

The results of the research revealed that caste considerations no longer play a vital role in different aspects of the social life in Kolkata. Different factors like the growth of communication facilities and urban development, the development of a market economy, the development of modern professions that are generally caste neutral, the expansion of education and special provisions made at the governmental level to benefit the lower castes (like reservations for them in educational institutions and government jobs), have resulted in the undermining of caste divides (Dumont 1980:229, Srinivas 2003:457). This is especially so in the state of West Bengal where as Basu (1992:109) notes, the higher castes have never been very powerful or cohesive, and the lower castes have never organized against caste domination. Thus implanted within this social structure marked by fluidity of caste boundaries, the caste identities of domestic workers did not emerge as a significant factor in the recruitment of maids. Moreover, as pointed out by one employer, since most of the maids originated from the lower castes, employers who had a preference for individuals from higher castes would find their choice greatly restricted. This may be a factor which could have prevented employers from pursuing the caste background of their employees. An employer Amola expressed her opinion on this matter in the following words,

I do not ask about their castes when they come to work. I look at the appearance and if they are neat enough and their work is reasonably clean, I do not have a problem... I have nothing to do about their castes. 
This and similar responses from other employers revealed that caste considerations no longer play an important role in the labour market of domestic workers. In personal communication, Dr. Ajitava Roy Chowdhury pointed out that the caste factor does not reflect in personalized relationships in contemporary Kolkata because the upper caste bias has broken down. The domestic workers also gave corroborative responses when probed on this issue.

However such probing exposed a different trend which has become significant the growing participation of Muslim maids in this occupation with the result that religious divides are making an appearance in the profession. While the employers were predominantly Hindu and the majority of the maids were Hindus, a small but growing number of Muslim maids have created new fissures and new alliances in this occupation. Muslims who form a minority culture within the Hindu majority in India have been influenced by the norms, customs and values of the dominant group of the region in which they reside (Lateef 1990 cited in Raju 1993:82). In a similar way, the role of Muslim women and attitudes to their employment are regulated by those followed in the particular region or community in which they inhabit (Mujeeb 1972, Ahmed 1976 and Lateef 1990 cited in Raju 1993:81). The fact that many Muslims in India are converts from the majority faith, also contributes to this feature (Saiyed 1992:3). Muslim women have therefore followed their Hindu counterparts to search for city based work in Kolkata as they too face displacement from their agriculture based village economies.

While the reactions of the Hindu maids were predictably hostile towards the maids of Muslim faith whom they viewed as competitors, the attitude of the employers towards the Muslim maids revealed a range of reactions. Some of the employers felt that similar 
to caste, religion was not an important criterion for them in selecting a domestic worker. However there were others for whom the religious faith followed by the maid was an important factor.

Traditionally Hindus worship God in the privacy of their homes and consider their homes as abodes for their deities. Some Hindus feel that the purity of their homes would be compromised if a person of a different faith (especially those who consume beef as the cow is held sacred in the Hindu religion) enters the inner sanctum of the home (Dumont 1980:133, Madan 1985:13-17). Although changes have come about in that the rigidities of such divisions have been eroded to some extent, they are far from having completely disappeared. Bratati, a young employer, expressed her concern thus,

When my mother-in-law was alive she would not have allowed a Muslim to enter her house. She may ask them to do outside work but not allow them to step into the house. I also follow her footstep and do the same.

Bratati exposed here a traditional mindset in that she did not want to deviate from a viewpoint held by an earlier generation. She is not alone, as some of the employers expressed a similar opinion. They were ready to employ these maids for outside work which mainly consisted of washing clothes and utensils.

My conversations with two Muslim maids revealed that they were mostly engaged in these two jobs which could be performed outside the house, such as at a neighbourhood pond or a tube well (an apparatus to draw up water for communities). While one of them worked with two employers in a long term arrangement, the other one worked purely in an ad hoc manner on the basis of temporary arrangements. She was on the lookout for a permanent job but had been unable to secure one so far. The employers mostly wanted them for jobs which a Hindu maid was not willing to do, like washing very heavy household linen which the Muslim maid would readily agree to do for a paltry 
sum of Rs. 10 (approximately 30 Canadian cents) per bucket of washing. Sometimes the employers also employed them during a crisis when their permanent maid was on leave, but these were mainly temporary arrangements.

The Muslim maids not only faced discrimination from employers but also faced the wrath of their Hindu counterparts who blamed them for depressing the wage level further through their willingness to work for lower wages and on short-lived contracts not acceptable among the Hindu maids. Some of the Hindu maids even charged them with faking their identities by dressing like Hindu women (wearing vermilion marks on the forehead and conch shell bangles on their hands) to secure employment in Hindu households. This was however vehemently contested by the Muslim maids who opposed such allegations of counterfeit identities against their community members.

Therefore there are two opposing trends that are being observed in the domestic service sector of Kolkata. Caste considerations are not important during the recruitment of the maids, which can be viewed as a socially progressive development. However there is also the disturbing trend of growing communal friction which is definitely against the secular nature of the Indian state. The former can partly be attributed to the social campaigns and legislations carried out by various levels of government to raise awareness and partly to the expediency of the middle class (majority Hindu) to tolerate individuals of the same faith. The second is due to the fact that economic compulsions are forcing individuals from different faiths into close proximity with one another, breaking the traditional segregated existence of these communities. The entry of the Muslim maids into this sector constitutes a major source of friction. 
Some of the employers who had not employed Muslim maids previously were gradually considering this issue as they regarded the Hindu maids to be too 'troublesome' and 'militant'. They perceived that the Muslim maids, due to their smaller numbers and greater vulnerability in the labour market, will be more amenable to their demands. As Purnima an employer said

I am not mentally ready for it [employing a Muslim maid] yet. But perhaps in the future I will have to give up this notion when I become incapable of coping with my work burden. My husband already has become willing to engage one. I have held on until now but may have to give in ultimately.

Purnima's growing willingness to engage a Muslim maid is clearly driven by her own compulsions rather than any secular mentality. However the thing to note is that whatever the cause may be, the gradual entry of the Muslim maids is further tilting the balance in favour of the employers as they try to tap into this source of cheaper (and so far largely untapped) pool of labour.

\subsection{The maid as the 'other'}

The difference between middle class employers and their maids is about more than differences between class and status. The 'moral deviance' of the latter is also a cause of concern for the middle class, arousing in them suspicion, doubts and distrust towards the latter $^{1}$. These cleavages are used by the middle class as a cause for its depreciation of the lower class. As outsiders in the family, the interest of the maid is considered to be inimical to that of the family. Their poor origins make them easy targets for accusations of theft and pilfering, with evidence being considered secondary. A tendency to conflate material deprivation with moral inferiority can be evidenced among the employers. It is a

\footnotetext{
${ }^{1}$ For a historical study of this aspect of domestic-employer relationship see Swapna Banerjee, 2004, Men Women and Domestics: Articulating Middle Class Identity in Colonial Bengal, Oxford University Press, pp. 166-172
} 
way that employers establish and justify their moral superiority against the depravity of the maid. In this regard Shampita, an employer revealed the following incident.

When I had first moved into this house all things were lying around haphazardly and at that time I had this maid...I found many things missing then. I had complained aloud. She said that she did not know anything about it and I could not blame her until I knew for sure. So after a time I got rid of her.

This account provided by an employer encapsulates a typical situation in the middle class employer's home where the mere suspicion in the mind of the employer gets transformed into conviction and forms the basis for the ultimate dismissal of the maid. The lack of proof is not considered to be enough ground to establish innocence. Denials of the accused do not influence the judgment as the employer possesses a predisposed notion of the likely candidate who could be accused of the guilt. This is despite the fact that by the employer's own admission, they had just shifted residence and misplacement of objects is commonplace in such instances.

Shampita is not alone as other employers also reported dismissals on grounds of suspicion. Amola, another employer reported the following

My present maid is not of that type but my previous maid was of that type. I had to always keep an eye on her. I had never caught her but I heard it from someone else that she had this habit. So I remained conscious about her.

The labeling of the maids as the 'type' for whom such misdemeanors were routine, normal and to be expected, provides the middle class with a higher ethical platform to vindicate its superiority. They were therefore saved from their qualms of equity and justice in denying the lower class considerations and sympathies normally reserved for the less fortunate. Through their own actions, either real or imagined, the domestic workers are therefore shunned out from the middle class's conscience. 


\subsection{Conclusion}

The employers of the domestic maids who belong to the middle class families of Kolkata employ external help to allow themselves to devote their time and effort to attain life goals which are more recognized. While the male members of the family delegate domestic tasks to the females, they in turn re-delegate it to the domestic maids whom they employ for this purpose. Changes over time and conditions have brought about certain changes in the profile of this job. Some of these changes, like a perceived lessening of honesty and devotion on the part of the domestic worker, meet the disapproval of the employers. Another change has been the growing participation of Muslim maids which have added further strains and stresses in the employer-employee relation. These are explored in a greater detail in the next chapter, albeit this time from the domestic maid's point of view. 


\section{Chapter- 6}

\section{Working conditions of the maids- Housework that pays}

The conflation of employment with empowerment (or the assumption of their inverse relationship) is analogous to the conflation of women and poverty and is in just as much need of a nuanced analysis which applies a gender critique to theories of exploitation... (Pearson and Jackson 1998:11 cited in Swaminathan 2002:70).

Paid employment is often comprehended to possess an empowering potential for women as it entails economic independence for them and their dependants and a scope for an expansion of their social and cultural horizons. Recent studies have however come to light which throws doubts on the existence of such an uncomplicated surmise. Pearson (1998) while reviewing her research findings on female factory workers has claimed that a wide gap exists between her findings and those of modernization and Marxist theories (Pearson 1998 cited in Swaminathan 2002:69). These theories revert to the simplistic assumptions of direct correlation between wage labour participation and slackened gender discrimination (Swaninathan 2002:69). The diverse experiences of employed women have made it imperative to take a critical look at both the categories of 'employment' and 'women' and problematize their general applicability irrespective of class, status, employment conditions or bargaining capacity. As Figure 6.1 below illustrates, starting from the early hours of dawn to late in the evening, the domestic maids have heavy work schedules both in and outside their houses leaving them with very little time to rest and relax. Their long hours and low pay contrast with middle class experience of employment. There is therefore the danger to lose sight of the difficulties that these women face in their occupation when a straightforward assumption is made that employment always has positive impacts on women's empowerment. 


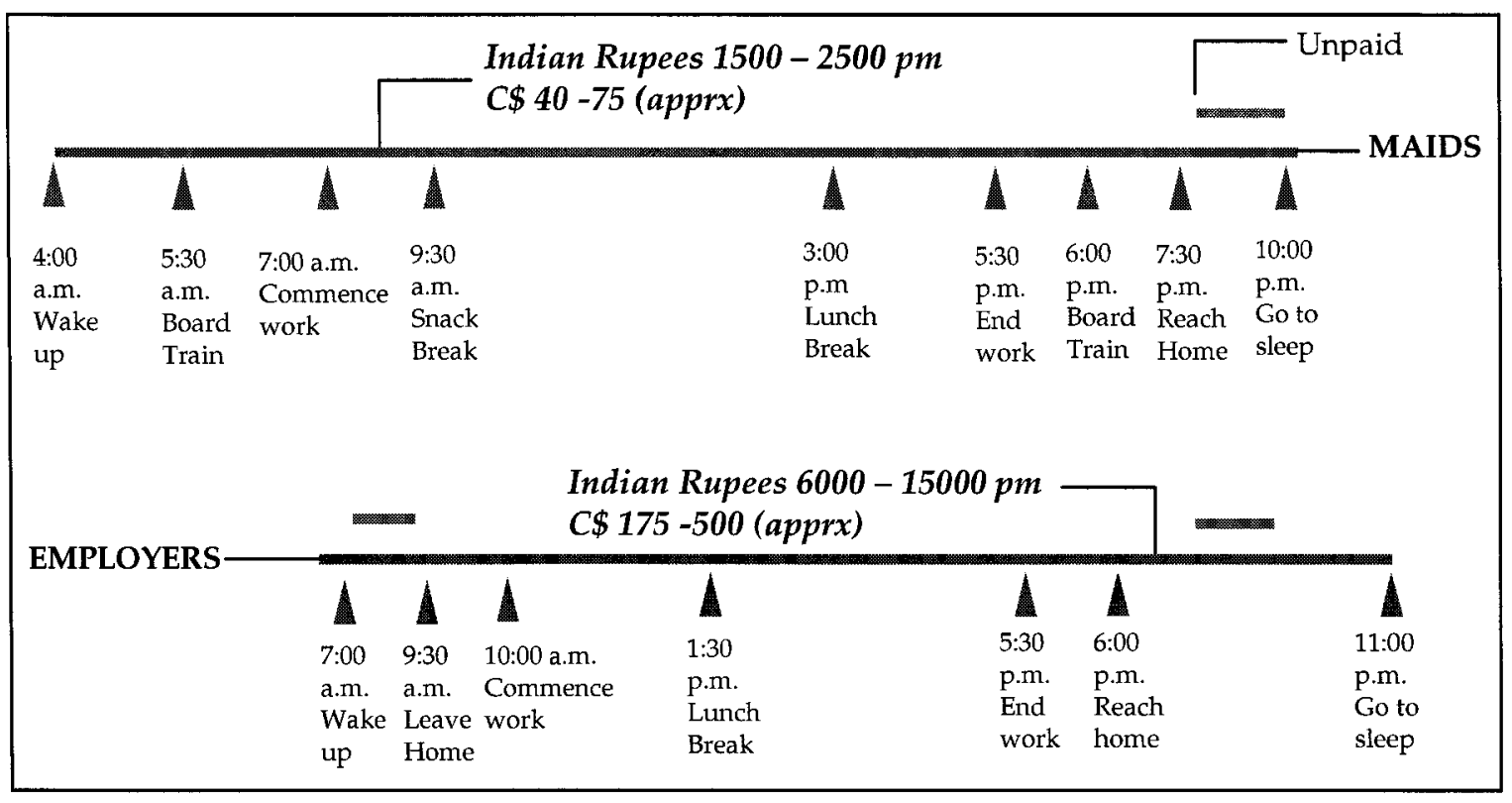

Fig 6.1 - Typical workday and wage rates for two different women in paid work

When a closer inspection is made of the context in which a worker's identity is shaped, sometimes framed by debilitating characteristics like 'unskilled' or 'semi skilled', or where work is premised on low pay and conditions inimical to the growth of women workers' consciousness, there is scope for doubts to be raised as to how much this employment is able to foster notions of women's liberation and empowerment (ibid).

Employment in India is categorized as being in the organized or the unorganized sector. The organized sector, as defined by the Directorate General of Employment and Training (DGE\&T) includes:

- All Public Sector Establishments which include all Government Services at the Central, State and Local Government levels;

- All Public Sector Undertakings in the field of agriculture, industry, credit financing, public utilities/services and 
- All non-agricultural private establishments which employ ten or more persons (Gopalan 1995:31)

The employment categories that remain excluded from this listing by deduction include the unorganized/informal sector and the self employed (Gopalan 1995:31). The vulnerability of workers in the unorganized sector can be gauged from the fact that this sector lacks any record under the factory legislation. These workers have no access to either steady employment or social security and have poor working conditions (Dutta: 2002:13).

An examination of the capacity of these two sectors to generate employment over the years in the country as a whole has shown a decline of the formal sector over time as its share fell from 9.69\% in 1971 to $8.51 \%$ in 1991 (Gopalan 1995:32). Women accounted for only $14 \%$ of the workers within the organized sector. In the unorganized sector on the other hand, there has been a phenomenal rise of women workers from 31.3 million in 1971 to 89.8 million in 1991 and the process has gained momentum with the passage of time (ibid). Women workers constitute $92 \%$ (1999 figures) of the total workforce in the unorganized sector in India (Dewan 1999:427). This immense concentration of women workers in the informal sector, whose salient features include low wages, low capital intensiveness, use of crude tools and lack of social security (Kalpagam 1994:234), raises grave concerns about their rights as workers. The non existence of any legal rights for workers in this sector renders it impossible for them to seek redress through labour welfare measures (Swaminathan 2002:95). The abysmally low wage rates and the ever present threat of dismissal have prevented them from openly challenging a structure that has perpetuated their exploitation as workers. The 
concentration of women in this sector may have an important bearing in explaining the obstructions to defending the rights of workers in this sector. The domestic maids of Kolkata who fall under the category of 'wage employees' in the informal sector (Kalpagam 1994:238) typically suffer from the disadvantages faced by workers in this sector.

In the first section in this chapter, I examine the everyday work experiences of domestic workers as lived histories and the industrious means of resistance improvised by them to strike discord against the master narratives of the society where women are considered secondary workers and the epitome of loose and subaltern feminity because of their compulsion to work outside. In the second section I take a more detailed look at their working conditions, beginning with an examination of their journey to work and back, the challenges they face at work, in negotiating their rights and responsibilities over such potential areas of conflict as extra duties, salary and food provisions. In the third and the final section, I deal with the meanings that this job has for the workers who are drawn to and participate in it at the present time.

\subsection{A contested terrain}

The role of women as paid workers in the society has faced challenges time and again. Historically their need to work for pay has most often been rejected by society where competition exists over limited resources that would provide the work, for example land or forests. By degrading and stigmatizing women who have ignored such divides, society has perpetuated this practice. However women have been equally 
persistent and successful in challenging and undermining such arrangements in diverse and unique ways.

\subsubsection{Deconstructing the male breadwinner}

The necessity of paid employment for women is often not given enough importance. The reason put forward to explain this is that her role inside the house is considered to be her primary role. She remains responsible for cooking, cleaning, collecting fuel, fetching water and the care of the young and elderly. From childhood she is initiated into this process which continues until death. Her closest socializing unit is her family, to be replaced by her husband's family after marriage. Society acknowledges her need for food, clothing and shelter. However the responsibilities for providing them, depends on the male members of the family i.e. father before marriage, husband after marriage and son during old age. Hence a widespread practice in the unorganized sector (though not totally absent in the organized sector also) has been to fix a man's wage rate in recognition of his responsibility of maintaining and providing for a family (Savara 1986:86). Thus, when a woman goes out to work to earn an income she faces prejudicial and dogmatic presuppositions. She is either considered to be a secondary earner in the family or be at the head of a family which has an absent adult male to look after its needs either due to death or desertion or simply being not present there in the first place. Both these situations weaken her claims for a salary equal to a male wage earner. Either she is a secondary income earner or her family is small, with the absent adult male lessening the consumption demands of the family (ibid:87). The belief that a man has a superseding right to enter the public space and participate in paid employment, reverberates with the 
gendered prejudices that permeate the operation of labour markets, resulting in an unequal distribution of power (Mishra 2004:130). The value of the work done is affected by the gender of the worker and women workers are in a more vulnerable position here (ibid). There is no recognition that the adult male in the family might be suffering from illness or may be unable to work. The domestic maids, some of the lowest wage earners in Indian society, prove in their daily life circumstances how much removed the stereotypes are from their lived experiences, where they are the sole employed adults in the family or fundamental contributors to the family budget. Women, in their multiple identities as mothers, wives and daughters play the vital role in augmenting the family's chances of survival and battle with poverty.

Sonali is a middle aged, married domestic worker who has been in the profession for almost two decades. She was orphaned at a young age and was not able to attend school. There are four members in her family consisting of herself, her husband and her two sons.

I have been working all along. My husband fell down from the tree. He was badly injured. Almost paralyzed. My elder son is mentally and physically retarded. My younger son is nine years old.

Bela is a middle aged domestic worker who was widowed at an early age. After years in this profession she perceives many more years of service stretching before her. This is how she fulfills her role as the principal breadwinner in her family.

When my children were young their father died. I had a son and a daughter to provide for. The daughter was one year old and the son was three years old. I started working then. Now my children are grown up. I have got both of them married off now. My son has two children. We are very poor. My son is not able to work very much as he has a weak health and he is always suffering from one thing or the other... I live with him and have to continue to work even now to support my family. When he is well he works as a construction worker. 
Mitali's description of her responsibilities shows how the survival of her family depends on her salary.

I keep some amount to pay for my transport cost and then give the rest over to my husband who buys the family supplies with them. I do not save any money. I have just finished paying off the debt for the jewelry that I had to give in my daughter's wedding. I also have to pay for my younger son's education. He also had serious eye problems and I had to make a number of glasses for him as he keeps breaking them off. Previously my daughter had a throat problem and I had to take care of that. Now it is my son.

Sushila, while describing how much her salary meant to her, narrates this incident when she had fallen ill suddenly at the beginning of the month which prevented her from collecting her salary.

I have got debts at the grocery shop, the vegetable shop. I pay about Rs. 300 if the bill comes to Rs. 500. After making the payments I make a small saving. I had nothing on my hand when I was struck with fever the last few days. I could not buy anything for myself as I had not been able to collect my salary before. I had to borrow Rs. 20 from my mother-in-law to visit a doctor at the end. The last Rs. 200 that I had with me, I had used up to pay for admission fee for my son's school. Now you can understand how we make our ends meet. My husband had been working at a tea stall but he quit after a theft at the stall. Now he is completely sitting at home. We cook only one meal and make do with the left over for the rest of the day. There is nothing we can do about it.

These oral accounts show how significant these maids' earnings are in a low income family, irrespective of the sex of the earner, to maintain the family's slender hold against the grind of poverty. These women spend a lot of time and effort in their work. They have to spend long hours away from the family even if the children are young. They have adult male members in their families who are unable to earn because of illness or laziness or because no option is available. They may have children who are ill and need care and nutrition, a powerful incentive for the woman to find wage work. The children also need to be educated and that means additional expenses to get admission to school, to buy supplies and arrange for tuition (as often the parents lack time or ability to guide them and the schools are overcrowded so that the students do not receive individual attention). In many cases the women have to make provisions of dowry to get their 
daughters married. The honour of the family depends on the daughter being married and sent off to her in-laws. The dowry payments arranged by her family ensures that she has a smooth transition to her new home and family. This responsibility forms a great economic burden on the family and becomes a source of immense financial strain on the budgets of poor households. This is a topic that I further elaborate in chapter 7 .

The lack of economic assets reduces the options open to poor families and this can sometimes have tragic consequences. For example Rita, a young maid who is a new entrant to the profession, with work in only two houses has the enormous burden of looking after five children and a husband who makes only occasional contributions to the family income. She narrated how she had tried complementing her income as a maid with work in the fields in her village. Her labour is the only asset of her family, where poverty, hunger and illness have left their deadly marks. When anybody falls ill in her family, she has to choose between medicine and food.

Sometimes even the presence of a second earner in the family does not provide respite, for instance, when their contributions are inadequate or irregular in nature and not commensurate with the family's struggles to gain stability in meeting minimum needs. For example, one maid explained how she was forced to enter an arrangement with her son (who is a co-earner in her family); she describes how her son sometimes bought the grains but not the fuel or bought the vegetables but not the salt. She maintains a strategic peace with him as she apprehends that her protests may worsen the matter and weaken the tenuous connections with her son who she suspects, may stop contributing altogether if pressured further. Her abilities to sustain and extend her chances of subsistence, depends on the delicate balancing and strategies that she adopts to obtain the best results 
from the options available. She therefore uses her income to take care of the remaining expenses as she feels ultimately responsible for the welfare of herself and her family members and thus exercises her control through covert means.

Situations such as these have prompted the maids to adapt diverse means to create more flexible options for themselves within the tight constraints of financial penury. They have taken up different strategies to curb spending and save funds for emergencies. This includes such self sacrificing measures as walking miles so as not spend money on transport or eating only the food available at the employer's place so as to save one plate at home. They also try to save money even though they have debt obligations at the market or from grocery shops from where they buy their supplies. This is another aggressive strategy they adopt to make provisions for an uncertain future where they have no assurance of continuing incomes. It is also a kind of distress measure to ensure the future as normal expenditure would result in the complete draining of their present resources. They use these pressures of debt to motivate themselves to work further and make some extra income (like washing clothes for households who do not employ them on a fixed basis) which is however irregular in occurrence. Their regular immense work burdens usually make it impossible for them to add to it further. But they use the threat factor of debts to explore further opportunities of their income generating capacity. Thus multi tasking or extra work is adopted in varying degrees according to the economic condition and the situations of the families of the maids. Sometimes it results in an acute crisis like in the case of Sushila who had spent up all her salary and could not even buy food or visit a doctor until she made a debt in lieu of the salary (that she knew was due to her, as soon as she would be able to join work). In such circumstances, maids depend on 
family or kinship ties as supports to tide over the crisis in situations when unexpected difficulties crop up due to very tight budgeting. In response to aggravated hardships women evaluate and reevaluate their options and come up with ingenious solutions to ensure the physical and social well being of themselves and their families.

\subsection{2 'Losing honour' in going out to work}

Cultural underpinnings of restricted operational spaces have also been important in preventing women from making autonomous and independent decisions regarding their economic activities. The ideology of female seclusion has held its sway over large parts of south Asia and is reflected in many practiced customs such as wearing of veil, restrictions over women's mobility and specifying accepted behaviour norms and modes of conduct (Afshar and Agarwal 1989:3). The reasons cited for such sexual segregation relates to izzat (family and personal honour), female modesty, controls over female sexuality and so on. But it would be wrong to say that these are rigid, time frozen, universal practices throughout this part of the world (ibid). There is a need to appreciate the fact that within this overall presence of an all pervasive practice of female seclusion, variations are equally commensurate with multiple impacts of regional, social and community practices acting as opposing influences.

Perhaps one of the most significant deciding factors has been the class location of the actors involved (Afshar and Agarwal 1989:3). As noted by researchers in India, poverty has a direct relationship with female work participation rates. Women in the lower classes have greater wage work participation rates than do women who belong to the richer classes, for economic reasons. Therefore when household income and male 
earnings are high, fewer women from such households participate in paid work while women from poorer households are more likely to do so (Chen 1995, Neft and Levine 1997 cited in Dewan 1999:426).

A study conducted by Ray (2000) among domestic workers of Kolkata in 199899, demonstrated how the construction of the image of the bhadramahila as someone who is protected, who does not need to do 'menial' jobs and whose sphere of activities remain contained within the inner workings of the family is used as a measure for 'othering' the maid who is subjected by economic pressure to pursue a different path (Ray 2000:696). The possession of lajja - shame and modesty - is construed as a determinant of the bhadramahila's virtue and respectability (ibid). Thus women who are unprotected and who need to participate in outside labour, such as domestic maids, are therefore excluded from the ambit of respectability. Even when the bhadramahila goes outside to work, she remains largely confined to genteel professions like teaching or medicine (ibid). Aspirations of higher social status among the working class can therefore lead to a desire to emulate the standards set by the image of the bhadramahila among women. Under such circumstances, the domestic maids who need to participate outside in physical labour have to draw on counter imageries to thwart the stigma of working women in the public space that attempts to cloud their respectability. Following are some of the excerpts from interviews with the maids which reveal the dynamic and diverse circumstances which guide their entry as well as their perseverance or withdrawal from the labour market.

Jaya, on being asked how her work has affected her status in society, provides a belligerent answer. 
Does it ever happen that you are respected when you work outside? When somebody tells my husband your wife goes to the city to work, will he not think that today, because my wife is working outside, I had to hear this?

Kumkum, a young maid, is not satisfied with her present status either.

I do not like having to work outside home. I am the wife of a family with a lot of fame. I do not want to harm that good name. So I want to be able to go back after working for sometime, say after six years or so and return to my village home.

Malati, in her answer to define her status as a working woman, captures the changes in the family's and community's perception towards working women like her.

When I had started working outside, my family members had warned me against it as it would harm my family's good name. Now many of my sister-in-laws work themselves. Now everybody tells me that you have done the right thing in remaining firm in your decision to work outside. In this way you can earn your own money so that you can take proper care of your children without having to take help from anybody else.

Sathi, a widow, explains her reasons to continue to her work even in old age.

Nobody in my family used to work in this profession previously. My brothers are educated and well established. They tell me that my work hampers their prestige. But I tell them that since they have given me in marriage in a poor family, I must earn and do something. My son also tells me that my work shames him. But I tell him that you may not always be in a position to give me money when I need it. So it is better that I have an income of my own.

Bela, who is a middle aged widow, shows how her working status has made her vulnerable to societal dictums. She described the humiliation she faced in her daughterin-law's parental home where she had gone to visit her.

[T] he next morning, I told them, you all are not speaking to me properly. My daughterin-law is kind of aloof. If you think that I am a bad woman as I work outside, you can scold me and take me to the authority that will punish me. You see I had become a widow at an early age and had to come out to work...Everyone knows me. Then my daughter-in-law's father who was a good judge of character scolded his family members and told them not to insult a friend of his. When I came back home with my daughter-in-law, I cried a lot and complained to my son and neighbours about the blame that I had to endure despite not doing anything wrong.

The complex interaction of societal norms and individual behaviour patterns, as revealed by the above narratives, throws open an interesting insight into the multitude of factors that women have to contend with and the diverse measures that they adapt to 
increase their options, resist criticism or cope. As pointed out earlier, women's labour remains an important asset which is used by poor households to keep poverty at bay. But the category of 'poor woman' is not a homogenized one.

There is a distinct hierarchy among poor women based upon perceived or material variations. These differences can stem from family status in the village society, age, marital status, or kinship organization. The family honour and especially the honour of the male members of the family are seen to have a direct resonance on the women's visibility in the work force. Women's outside engagement in wage work is perceived as a reflection of the inability of male members of her family to provide for her or her dependents. But there can also be a gendered reading of the text as is evident from the case of Bela. Her experience shows that when a woman steps outside to work, it can be interpreted as being the result not of material needs but as an action directed by her sexual orientation. Her transgression of the 'male sphere' makes her an object of suspicion and makes her susceptible to attacks, irrespective of her age and status in the family, as a mother-in-law who in other circumstances has the most assured position of respect among the females in the family. However her status as a widow and a working woman has created space for her daughter-in-law and her family to challenge her. The lack of a male 'guardian' has made her vulnerable to criticism about her movements. Again, if we take a closer look at the narratives of the two widows, Bela and Sathi, we can detect that Sathi has a more assured position in her family than does Bela. This may be because Bela was widowed at a young age and started to work much earlier. Sathi on the other hand had entered the profession when her husband was alive and had been widowed at a more mature age. So Bela's age of entry into the labour force as a young 
widow made her more susceptible to accusations about her sexual reputation. This reaffirms the fact that in a patriarchal society a young widow is seen as a female without 'protection' and thereby more susceptible to predatory sexual behaviour by males.

In the case of married women, the governing factors may be slightly different as society holds the husband as the primary guard of her virtue. In the case of the husband's illness or incapacity or lack of work, the responsibility shifts to the wife to fulfill the 'father's obligation' to the family, that is to provide for its needs. This too is not easily attained. Only those who can persevere and use the returns of their labour to benefit their children, husband and larger family, stands to regain prestige in her society and sometimes also emerge as the trend setter, as Malati's case demonstrates.

As revealed in the narratives, the women have also adapted and used various measures to enhance their competitive potential and deal better with the repression, either in an individual or collective capacity. The use of persuasive weapons like hunger and poverty to stifle criticism is a frequently used strategy. As a maid pointed out, despite her efforts of not allowing her daughter to work before marriage, she was unable to stop her from doing so after marriage, as the other alternative was to starve to death. She portrayed herself as a powerless victim against the superior might of starvation which had bound her to remain silent when her daughter took her neighbour's help to find work.

Another commonly used tactic is to use the societal ideology of good mother and good wife to defeat the hurdles that prevent women from taking up work outside the precinct of the home. Domestic maids often point to the enormous burden of their husbands as single earners who need to support an extended family consisting of children and old in-laws. They evoke the sympathy of the society by using the ideology of the 
ideal wife who shares all the burdens of her husband including economic ones to bargain a position for themselves in the labour market.

An additional mechanism that has also been reported by field researchers is 'public chaperoning' (Lessinger 1990: 138) whereby some essence of seclusion is maintained. The maids often travel in groups of their own. While this may seem a logical move in order to find security in each other's presence, either when they set out from their homes, or when they make their way back, there is a need to attach increased significance to these deliberate groupings. The behaviour of the maids during their journeys, are all keenly watched by the other maids, and gossip or rumour about an unacceptable behaviour can spread quickly within the community. But on the other hand the network can also be used by the maids to draw public sympathy and security towards themselves, as Bela's case confirms. These networks are therefore valued, and efforts are made to conform to general rules and informal dress codes, such as using a part of the saree (women's dress) to cover the head, putting the vermilion dot on the forehead and the vermilion mark on the hair parting and wearing conch shell bangles on the hand, as emphatically displayed signs of married women whose sexuality is bound up within the marriage structure and serves as a warning against male 'sexual predators'.

Another point about domestic service as an occupation that should be noted here is that this occupation occupies an ambivalent space in the interface of public and private domain (Raghuram and Momsen 1993:56). A further link between this occupation and the ideology of female seclusion can therefore be drawn. As most of the interactions that the domestic worker has in this job are primarily with female members of the employer's household, it has meant that women are accepted in (from the perspective of the 
employer) as well as accept (from the perspective of the employee) this job as less threatening than other occupations where interaction with the opposite sex may be more frequent (ibid). As pointed out by Ray (2000:698), the adult male in the house seldom speaks to the female domestic who in turn is extremely reluctant to address male employers.

\subsection{The travails of work}

The value that society attaches to a profession is expressed in the form of material rewards such as wages and benefits and through symbolic gestures such as respect and recognition. In this section I look through the two lenses of the material and the symbolic towards the occupation of domestic workers to establish how both these means of recognition have been denied here as a mark of society's neglect and derision of it.

\subsubsection{Experiences of commuting}

Statistics suggest that in India, females outnumber males in migration when it comes to movement over short distances. The most plausible explanation for this phenomenon is that women in north India migrate after marriage to live in their husband's residence (Dyson and Visaria 2004:108). However when migration results from a search of better economic opportunities, it is males who outnumber females and the migration literature abounds with examples of females being the principal group to stay in the rural areas to look after the home and the family (Neetha 2003:118).

However developments have started coming to light which focuses on newer trends. One such development has been the rise in female long-distance commuting and 
the complexities and entanglements associated with it (ibid). The maids of Kolkata present one such interesting variation. Improvements in transportation facilities, especially the running of local trains since the early 1960s have meant shrinkage in space and time with greater interconnecting flows between the city and the suburbs. As a consequence, the linkages have increased in number and strengthened the cohesion of the city's communication system with its suburbs. Such changes have had a remarkable effect on women's mobility especially for those groups who because of marriage or other family responsibilities remain tied to the vicinity of the home. This transport system has ensured greater flexibility in their circulatory movement between their residences which remain separated by great distances from their work sites. The movement of women from the suburban areas of Kolkata, especially the southern suburbs which are well connected to the city by electric trains, has increased proportionally as a result of this development.

The experiences of commuting have however thrown up newer challenges for women. A monthly ticket, the price of which varies depending upon distance traveled, has become an issue of contention between commuters and railway authorities as ticketless traveling is rampant. Traveling without a ticket in trains for short distances has become more or less a norm outside the city limits (Chowdhury 2002:168). The widespread acceptance of the practice can be gauged from the fact that many of the ticketless passengers are higher class office-goers and students as well as the passengers of the poorer classes (ibid). The maids form a substantial section of these ticket evading passengers (Chowdhury 2002:167, Roy 2003:194). The railway administration has tried to deal with these issues by conducting special ticket checking drives on railway platforms or in-car inspections. Sometimes a special inspection car is 
brought in which carries the ticketless boarders to be locked behind bars maintained by the railways. The inspection car is named Chetona (Realization) and as its suggestive name indicates, is an attempt on the part of the railway authority to generate awareness of the illegality of ticketless travel. However, woven within this grand narrative of official discourse which strictly regulates offenders, are instances of deliberate lapses by the policing authority and of dissent in the policed body of the maids which generate an opposing space that allows the irregularities to continue and thrive. In the following excerpts, the maids try to locate these discursive spaces of opposition.

Alpona describes here her reasons to avoid buying tickets when ticket checking drives are absent.

I leave home at 4.20 in the morning and then come walking to the station. Previously I never used to buy tickets. However now as there are frequent checks, I buy the monthly ticket which costs me Rs. 140. I do not know what we pay for as we travel without sitting on both ways in very crowded trains which tires us. That is why I sometimes avoid buying tickets when the checks are not there.

Mitali provides the following explanations for traveling without a ticket

I get up at 4.30 in the morning and catch the 5.30 train. I can come to the station by van rickshaw by spending Rs.3. But I generally make the journey on foot. If I spend my money in traveling what will I eat. The employers do not understand. I do not usually buy tickets but when I get to know about on-going checks, I buy one for that journey.

Bithi explains here how she oscillates between periods of buying and not buying tickets.

I got caught twice. They took me to a faraway station. I was crying all the way. Then they let me go. After that I returned home with great difficulty. I then bought tickets for two months despite my financial hardships but they never came checking during that period. So I went back to not buying tickets any more.

Kanak describes how the maids cooperate with each other to protect themselves during checking drives.

Today in the morning they were checking tickets in our station. Those of the maids who possessed tickets showed it and engaged the checkers while others quietly made their way out. 
Reflecting on the account provided by the maids, it becomes evident that ticketless traveling has become an issue of contention between authorities and passengers. The ambivalent nature of the issue involved can somewhat blur the immorality of the act. The cost of the monthly ticket can be a substantial part of the monthly earnings of the maids. The maids who travel great distances and spend long hours at work in different houses, still earn very small wages. They are therefore reluctant to part with the small earnings that they make in order to buy a ticket. If it is to be ensured that the maids buy tickets, their salaries need to be raised by at least Rs. 20 per household immediately (Chowdhury 2002:170). Not many of their middle class employers would be agreeable to such suggestions (ibid). Even if hypothetically they agree to increase the salary of the maids, there is no guarantee that the maids would use it to buy the tickets, given that they have multiple demands on the scant resources that they have at their disposal (ibid). The employers feel a sense of success when they resist the demand to increase the wages on account of the railway tickets. However they do not realize that the government uses the taxes from their income to subsidize the operations of the south suburban railways (ibid:168). This section of the railway currently runs at a loss (ibid) and the employers would lose heavily if the railway services were curtailed due to the paucity of funds. Although successful in their bargaining with the maids (given the obvious power differentials of the two parties involved), the employers have to adopt a more humble stand and agree to pay their tax dues fixed by the government. They are therefore being forced by the state to pay for services utilized by the women engaged in the informal sector. 
The maids justify their evasion of buying tickets on two factors. The first reason that they cite is the very low wages that they receive. The uncomfortable nature of the journey that they have to endure is also a major deterrent. The very crowded nature of the trains where there is little room to sit, stand or move comfortably, is used by the maids as an excuse to avoid buying tickets. They also derive strength from the company of other maids with whom they share a commonality of circumstances, even if they are from different areas (Roy 2003:196). Their shared vulnerability when gathered together at the railway platforms or within the train compartments provides them with a certain force to defy authorities, which perhaps may be lacking when they deal individually with their employers.

Again they sometimes use a gendered response to ward off aggravation from the authorities when their ticketless status gets detected during inspection. From experience, they know that authorities mete out different punishments to male and female offenders. While males are detained for such offences, the authorities take a more lenient stand towards the females, probably because of a lack of separate lock up arrangements, as revealed to me by a ticket checker during one such inspection drive. Repeatedly, during the field study, cases came to light where the 'truant' maids were set free on a different station after being initially captured. There was no maid who reported having spent a day at the railway lock-up due to the offence of ticketless travel. Although there was much embarrassment and discomfort involved in being arrested and set free in a different station, the maids know that eventually they will be spared from being put behind bars. In fact many of the maids reported how they were encouraged by the ticketing authorities to collect small amounts from their co-passengers so that the combined amount could be 
used to give them a single fined ticket. For example, when the amount of a single fined ticket was Rs. 60 , three or four maids pooled together their gathered resources to pay up a single fine and were then set free. The women used the gendered tactics of crying and pleading to evoke a more favourable response from the authorities towards them. They portray themselves as helpless poor weak women to prevent the authorities from taking a sterner stand against them. The authorities on the other hand, assume a stand of a superior condescending male persona who forgives the females.

\subsubsection{Struggles at the site of work}

Domestic service as an occupation has certain distinctive attributes which sets it apart. The site of work is private. This conflation of the home and work place leads to the creation of unique relations of production and specific situations of work not found in other occupations. The employers are not a homogenous group as they differ in their economic and social standing, their expectations from the maids and the responsibilities that they feel towards those who they employ. As a result, the relationship between the employer and the domestic maid differs from one situation to the next. Also the nonstandardization of wages, hours of work, duties to be performed, benefits to be derived and other such particularities add to the undefined nature of the job (a snapshot of the non standardized nature of the work conditions is provided in Appendix-A).

The lack of precise conditions of the service creates room for discrimination. The unequal distribution of power between employer and employee becomes more aggravated as the bargaining parties enter into individual unwritten contracts at the beginning of the service which leaves large room for manipulation later on. Again, even though 
theoretically both the parties can end the contract at any point of time and terminate the arrangements, in a labour surplus sector, the employee suffers from inherent weakness in comparison to the employer. Under such circumstances, the domestic worker who finds her labour power getting unfairly exploited finds it hard to resist. The employer, who has assured replacement labour available, tries to drive a hard bargain in imposing extra work, stagnant wages, reduced benefits and lesser holidays. The employee has to resort to covert means of resistance in order to protect her rights from getting eroded in a labour market where the specter of unemployment threatens to overwhelm the small choices and little victories they still enjoy. The following narratives demonstrate the multiple hostile encounters that domestic maids face at the site of work and how they try to resist the erosion of their rights.

Sushila discusses here her various duties and the low wages she earns from performing them.

I mop the floor, wash the utensils, fetch water and wash the clothes in each of the houses that I visit. Each of the houses I visit twice and sometimes thrice. They are all heavy work. But the pay is very poor. About Rs. 350 or 250 per house... When I had started working in Pancha's house about seven years back, my salary was Rs. 150. Now it has increased to Rs.200. So in seven years the salary has increased by only Rs. 50.

Sonali works as a part-time maid in three houses in addition to cooking in one of the houses. She describes here her unhappiness with the work conditions that she endures everyday.

When I first start work, they talk of certain duties but then afterwards they go on increasing these jobs without additional payments. I have to do it as I fear that otherwise I will lose my job. In one house I have been working for 15 years now. Only when they added a room and a balcony they increased my salary by 100 rupees but stopped giving me the food that they gave before. They tell me that the salary has increased but they do not see that the work has increased as well. They offered me instead to make a cup of tea and have it with biscuits. But I said that I do not want it. What would I do with a cup of tea? So now I buy snacks from the road. When I return home I cook a meal for everyone to eat. 
Kanak works in five houses. She narrates here her frustrations for the little recognition she receives for her efforts to satisfy her employers.

Sometimes when they ask me to do extra work I do it. I get paid at times while at others I don't. I do not demand anything. During the festivities they may give us a saree. I tell them then that you have not given me anything throughout the year, so you give me a good saree this time. Sometimes when I need money more, I do not take a saree and instead take the money. Sometimes I feel very sad about it when I have to listen to a lot of abuse before I get a thing that I wanted from the employers. I tell my employers, 'You are closer to us than our family and we can only ask you for certain things that we cannot get for ourselves. We try to do all the things that you ask us to do'. If we ask for an increase of a salary after working for a full long year, they may increase it by Rs. 5-10 or they may ask us to discontinue as they will replace us by a better maid who will work for lower wages for them.

Shyama is a middle aged maid who works in three houses. This is her description of the treatment she received after she was forced to extend her holidays by a few days due to circumstances not entirely in her control.

\begin{abstract}
I take five days of holidays in a normal month. Once because I had taken more leaves than I told them I would, they kept another maid before I returned. At that time I had asked them that I would take three days leave as there was a festival in my house. During these days I had to work hard in my house at cooking meals for the invited. So I took two extra days of leave. When I returned they told me that they no longer required my services. They however asked me to do work for them for one month during the festivities in their own house. I said 'Yes', but I knew that I would not return as they were asking me to work for a cause for which they had penalized me themselves.
\end{abstract}

Mina, another maid, describes here her coping strategy to deal with angry employers when she returns from taking a sudden leave from work.

Sometimes it may happen that I may not have been able to get up in time and therefore could not come to work. You cannot tell the truth to your employer as otherwise you receive a lot of scolding. They start with, 'It is you who always fall ill.' So I have to make up something to say in order to save myself. For those employers who are more lenient, I tell them the truth that I did not come as I did not feel like it. For the stricter ones you have to make up stories (laughs).

The narratives presented here provide insights about the vulnerabilities and insecurities faced by the domestic maids at their sites of work and their efforts to create spaces for themselves to at least retain a small degree of control over their labour which is daily threatened by the onslaughts of greater demands. The priorities of the employers 
and the maids directly oppose one another. While the employers can use easier and strong arm tactics of denial, threat or ultimate dismissal, the maids who constitute the weaker link, have to use their discretion and mask their opposition in more acceptable forms of behaviour. Conflicts break out over questions of extra work, salary, holiday and other benefits. The maids, in their effort to depict themselves as humans instead of bodies infused with labour power, deliver a critique to the system that otherwise portrays them so.

\subsubsection{Extra Work: The 'Choice' of Saying No}

The question of extra work is a widely contested issue for domestic workers. While employers vehemently deny that they impose the burden of extra work on their maids especially when they are part-time, the maids allege that not only do the employers breach the agreement entered into at the beginning of the service, when they impose extra duties or go on adding to the burden of duty, but they also deny paying extra money. For example, a maid pointed out that when she first began to work, she was promised that she needed to wash just three items of clothes for the three members of the family everyday. But gradually, as the days passed, the number of items went on increasing as bedcovers, bed sheets and curtains were added. Such a situation brings to light how the lack of a proper and well specified contract can lead to the exploitation of the worker. In such cases, although both the parties are well aware of the specificities of the unwritten contract (this is evident from the fact that they both stick to the initial agreement in the early part of the service), with the passage of time, a slow encroachment of territory is attempted. It is mainly initiated by the employer who enjoys the upper hand within the 
power game. The maids in their response are well aware of the fact that new machinations to their disadvantage are afoot. Although their choices are limited, they try various means to protect themselves from external attempts of appropriation of their labour power. One common means adopted in such circumstances include deliberately delaying the duty to be done to the next visit. Often the inability of the employer to wait for the deferred service leads them to complete it without the help from the maid. The maid therefore escapes from having to directly confront the employer on the issue. Sometimes they also deliberately mismanage the task so as to frustrate further ambitions on the part of the employer to relegate extra work burdens. Through such attempts, the maid tries to restore control over her rights.

However implicit within such attempts is also present the maid's endeavour to avert a complete alienation of the employer. Her consciousness of being a worker in a sector where the employment potential is stagnant prevents her from taking a more militant stand against the employer. Yet sometimes she is forced to take this extreme position when all other avenues of protest are closed. Some maids reported, having to give up working for a particular employer when the burden of work was in no way commensurate with the salary being paid. While the maids agree that they need to stay in a job more than ever, they are also conscious of the fact that if they allow uninhibited exploitation of their labour, it can only lead to a progressive slackening of the slender control that they still exercise in the exchange. In their choice of being actors rather than acted upon, lies a clear protest against the oppressiveness of their work conditions. 


\subsubsection{Wages of Subsistence}

The wages paid to domestic workers is another area of concern, given that they have remained persistently at a very low level (Kasturi 1990:79). Gandhi and Chowdhury (1984) point out that the most commonly performed three tasks that are done by part time domestic workers include washing clothes, scrubbing utensils and mopping floors. Many maids also reported a variety of other jobs that they needed to perform, such as fetching drinking water, grinding spices, cleaning utensils that are used to offer edibles to the deity $^{1}$ and the like. During my field work, I found that though the wages were paid on a monthly basis, there is no evidence of standardized rates of pay in Kolkata. The near stagnation of their wages when contrasted with increasing inflation rates, ${ }^{2}$ is an indication of the downward pressures experienced by them in their standard of living (Gandhi and Chaudhury 1984:118).

At the initial meeting where the wages are fixed, the general practice is for the employer to list the number of duties that she expects the domestic worker to perform. This is how a domestic maid describes a typical first meeting where duties and wages are bargained for.

I ask about the nature of the duty that I need to do. I also look at the number of family members because if they are more in number I know I have to do more work. I also look at the number of rooms and staircases that need to be cleaned. After that I tell the employer what I expect as salary. They say, 'Do not ask for this much at this stage. You start at a lower amount and we will gradually increase as time passes on'. They may increase it by Rs. 10 after the passage of one year, while some may do it after three years. I have been through it so I know.

The above conversation reveals that in the absence of either legal or customary practices, fixing the salary is dependent upon the bargaining strength of the two parties involved.

\footnotetext{
${ }^{1}$ These are separate plates and glasses in many Hindu homes to offer food to God during prayers or Puja

2 The inflation rate (wholesale price index) in percentage was $3.6,3.4,5.3,5.0,4.7$ in the years $2001,02,03,04$ and 05 respectively (Asian Development Outlook 2004).
} 
While the employer tries to make the duties seem less and light, the maid tries to gauge the truth behind such statements. The careful consideration that she reserves to such questions as the number of family members and the number of rooms and staircases that need to be cleaned, demonstrates her efforts to make an independent judgment of the situation. Here a clear conflict is evident between the employer and the employee as each tries to usurp the other's initiative and undermine the rival's attempt to draw a hard bargain. However the incipient weakness of a worker in the informal sector becomes evident in the final stages of creating the agreement. Despite the fact that the domestic maid gets to state her expectations, it is an empty bargaining chip as the employers quote the ultimate salary they are willing to pay. At this stage too there is an attempt by the employer to seize the momentum of the bargaining process to the maximum extent. The maid is lured into the job to start at a lower pay with the promise of future rewards. Although the maid realizes the implications of this and is not ready to concede to the image of a naïve believer, she is again handicapped by the limited choices available to her. She has to either accede to the low pay and take up the employment, or she can give it up. There is thus need to interpret her accession as a subsistence strategy in a sector which is experiencing overcrowding despite the prevalence of low wage rates.

\subsubsection{The Politics of taking leave}

During my study of domestic work in Kolkata I noticed that one of the most contentious issues was the question of leave. While the employers fervently try to restrict the practice through threats and actual wage-cuts and termination of services, the maids use it as a covert mechanism to discipline the growing authority of the employers. The 
interviews with the domestic maids revealed that their efforts have been to establish at least four days of holidays per month. However the establishment of the norm is widely contested by the employers who regularly challenge the boundaries with counter claims of excessive and un-notified leave taken by the maids as instances of irresponsibility which render them unsuitable for further consideration.

The domestic maids accept these challenges and, as part of their endeavour to defend their rights of leave-taking, offer a variety of counter claims. As Mina points out, she reserves separate responses for employers of different temperament. She uses her familiarity and past experience to make a discrete division of her employers into 'reasonable' and 'non-reasonable'. In order to save herself from the admonishments of the latter that she feels is assuredly awaiting her on return from a sudden leave, she is ready to transgress the border of honesty. She is not perturbed to make up fictitious reasons for her leave, for those employers who would admonish her for any reason whatsoever. She further believes that her integrity is not broken as long as she tells the truth to those employers who empathize with her.

The maids generally consider that a leave for four to five days a month is a legitimate compensation for their labour. However the employers do not accept this position and grudgingly allow a couple of days as adequate time off. The employers also demand that they should be given the notice of leave beforehand as they would have to prepare for the absence. The maids therefore inform the employers of their intention to take leave on one or two days per month. If they take leave on additional days they do so without prior intimation. The maids have deliberately used this policy, of not intimating their employers before taking leave on additional days, for a major reason. They contend that 
if the employers know that they are going on leave, then they will increase the workload to compensate for the time taken off. The maids feel cheated as in effect they have to do the work that they want to escape from on those days. The meaning of the holiday is thereby diluted in their minds. However as threats of wage reduction and the termination of service are painful realities, the maids use this strategy sparingly. Herein lies the maid's attempt to portray herself as an innocent victim and not as unruly and undisciplined as claimed by her employer. Her inability to directly challenge the 'hidden intentions' of the employer has made her adopt a more insidious means to register her protest. The consciousness of her rights as a worker consolidates her resolution to retain part of the control on her labour.

The lack of honesty and fairness apparent in these situations is also contributed to by the employers. As Shyama's case demonstrates, some of the unannounced leaves are taken on genuine grounds. A sudden illness or difficulty in the family, a sudden indisposition on the part of the maid herself, or a need to take a break from the hectic schedules of the maids are genuine grounds on which a leave can be granted. However as Shyama's case shows an unsympathetic employer can use it as an excuse to dismiss the maid. The question of employees' leaves in this sector therefore remains an ad hoc arrangement largely depending on the discretion of the employer. There is no pay granted during maternity or sick periods, forcing the worker to return at the earliest moment. Sometimes even the earliest returns are not guarantee enough to retain employment as Shyama's case demonstrates. In the circumstance of rising unemployment, these women remain trapped in occupational ghettos which severely limit their options to take a bold stand against the employers. It is therefore in the quiescence of their silent action that 
there is need to find strands of resistance. When Shyama quietly agrees to return to her employer's house from which she had just been dismissed with every intention of not honouring that promise, she is making a resolute stand to dispel the myth of consenting maids. This is her way of defining the very edge over which the workers of this sector have been driven to by the inherent insecurity of their work.

\subsubsection{The Disappearance of Other Benefits}

As domestic work is a service provided in the privacy of homes, a concomitant aspect that results from it is the growth of personal relationships between the employer and the domestic maid (Neetha 2003:127). Different benefits provided to the domestic worker in terms of food and clothes, extra money and medicines, may be seen as an extension of these personal relationships. Food items, clothes both old and new, extra money and/or a new saree during festivities, monetary debts in small amounts in times of need and crisis and in very few instances, some medical help in the form of common medicines kept at home for simple ailments were listed as benefits received by domestic maids in this sector (refer to Appendix-A). However as Mitter (1991:39) points out, these benefits are highly personalized in nature and is in the form of dan (a gift) which the domestic maid can anticipate but never demand. With growing formalization and impersonal aspects of the job, there has been a gradual dwindling of these benefits (Neetha 2003:128). The uncertainty of the gifts, the giving of which depends on the disposition of the employer, has become a matter of concern for the employees and some of them have started to prefer monetary wages determined beforehand, releasing them from having to depend on the goodwill of the employer. The employers try to discontinue 
or restrict the practice of giving gifts to the employees so as to avoid responsibilities towards them. Thus as both the employers and the employees prefer direct money as the sole form of payment, this has led to a gradual decline in the giving of gifts on the part of the employers. The maids regret the progressive abolition of this tradition. The account given above by Sonali and Kanak, points to this trend. Sonali regrets her employer's action of cutting back on her food while increasing her salary. She views the salary increase as commensurate with an increase of her work load. She therefore considers her employer guilty of denying her a just return for her labour. She rejects the cup of tea offered to replace the food items provided before, as a symbolic rejection of the loss of empathy that previously existed between her and her employer.

In the case of Kanak, a similar process is seen, as she voices her regret at the growing loss of familial relationships that is set to make a disappearance with the growing formality of the job. Her attempts to relate her dependency to her employers is also an effort on her part to raise their consciousness about their responsibilities towards those who are less materially endowed. In the larger context, it can also be interpreted as an effort on her part to arouse the society whose commitments should lie in collective responsibility, concessions for the poor and the anxiety for the welfare of all. She therefore delivers here a critique to the emerging society driven more and more towards the marginalization of the poor in an effort to reach the lowest minimum costs to provide comfort for a few. 


\subsection{Prisoners of 'choice'}

Given the low wages, long hours and hard work involved in the occupation of the domestic worker, I felt a need to enquire during my fieldwork, about the reasons for its persistence. The question seemed to be particularly apt to me as many of the maids reported not only their continuance in the job but also a growing competition in it. As Roy (2003:199) also recounted from her observations of commuter maids made in 199798, this occupation was characterized by a surplus labour supply which outstripped demand and was a contributory factor to the low wages found in this job. Therefore as a corollary to this exercise, I started to include a question on this subject during my interviews with the maids. My inquiry was directed at efforts to find what other employment was open to these women and to explore the reasons for their rejection of these choices as non-viable.

\subsubsection{The Prospect of alternate employment}

The principal reason that I detected from the responses to my inquiry was that the depressed economy of the region had resulted in severely restricting the employment options for these women. One of the important factors which have caused their migration away from the rural areas has been the growing pressure of population on the land. Agriculture has remained a prime economic activity in India, engaging 59\% of the total population (Ghosh 2004:5109). While agriculture has been one of the triumphant achievements of the Left Front Government's rule in West Bengal, due to the absence of further innovation the growth rate has started to decrease (Banerjee et.al 2002:4213). The slowing down of agricultural growth has brought about stagnation in agricultural 
productivity. As a consequence, the landless agricultural labourers have been the hardest hit, with women taking the maximum brunt amongst them. Displaced male agricultural labourers have been less affected as their dislocation has been somewhat offset by the comparatively greater assets that they command. The assets have been built up due to multiple factors, two important ones being, customary law which favours the son over the daughter in matters of inheritance of property (Banerjee 2002:50) and higher wage rates for males even for similar types of work especially in agricultural operations (Banerjee 1985:150). These assets can be subsequently used by the displaced male agricultural labourers to diversify to other jobs like trade and marketing. However the women who lacked these assets underwent notable dispossession and loss of status. Thus even while agriculture still remains the single largest sector providing employment to women, there has been a gradual decline of the number of women employed in this sector. While agriculture provided employment to $90 \%$ of rural women in 1961 , this proportion had fallen to $86 \%$ in 1994 (Banerjee 2002:51). Many of the maids (seven in the sample size of twenty) reported to be engaged in different agricultural activities as labourers and market gardeners in the past. The main reasons singled out by them as contributing factors which forced them to discontinue the agricultural operations were the nonavailability of work, seasonality of work and irregular pays. This is what Sonali had to say,

There is work in the fields, in the orchards. But it is better to work in the city. If you work in the fields the pay is very low and you frequently do not get paid... They may pay you after a week but what will my family and I eat during the week. Also the work is very irregular as you work for two days and then sit back for seven days without work. When I work as a maid, I get a steady income. I have a fixed grocery shop from where I get my whole month's grocery for my family. I pay off the accumulated amount when I get my salary. 
The need for a stable income for these women is a major consideration as poverty and lack of assets requires them to constantly invest their labour in income generation. The rate of payment in agricultural operations is on a daily basis but women face problems when they receive their pay irregularly. The lack of social status and weak bargaining power means that they cannot ensure this unless they increase the boundaries of their movement which may take them away as far as the cities. Domestic work, despite its disadvantages, ensures a regular monthly income. Provided that the domestic maids can establish work arrangements with certain employers, they are assured a wage so long as the service period is not terminated. A comparative evaluation of job options available to them therefore makes them decide in favour of the job of the domestic worker.

However working in the city means undertaking long and tiresome journeys and spending a large amount of time away from home. So some of my inquiries were also directed to explore the non agricultural activities that the women could take up as an alternative to both agricultural occupations and city based occupations which required a great deal of commuting. While most of the women could not think of any such alternative, the very few who could, thought that the low rates of pay and the irregularity of the work negated any comparative advantage that they had against domestic work in the city. This is how Malati describes her rationale for taking up the job of a domestic maid.

There is some work available in the village which is done on a piece-rate basis. But the pay is not enough. Like one thousand pieces may fetch you only Rs. 3-4. Also when you stay at home you do not find enough time after having to do all the housework which takes away a lot of your time. In this job you get out of the house in the early morning and need to do the housework only during the evening when you go back home.

Reflecting on Malati's experience, one can see how domestic work has become relatively attractive option for women. As Malati points out, the pay is on a piece-rate basis. The 
preparation of one thousand pieces just fetches a paltry sum of Rs. $3-4^{1}$. This means that if this is the main source of income for the principal income-earner of the family, as the maids often are, they require a lot of time at their disposal to fetch a reasonable income. Although the work can be done in the confines of their homes, this option is not very attractive as women also remain primarily responsible for the reproductive tasks within the family, including cooking, cleaning, childcare and the other similar duties. Through their everyday life experiences, these women have realized that their role as mothers, wives or daughters impinge on their role as workers if the sphere of work and home coincide. Responsibilities in their different roles will compete for the time that they have at their disposal. As both roles are important to them, they would be in a difficult position to decide and devote adequate time to each while remaining in the house. The rational approach adopted by them has therefore been to segment the work hours of the day into different sorts of work. While such a choice may entail long journeys to work, they have accepted it as the price to be paid in order to attain a better means to gain a return for their labour.

\subsubsection{The meaning of being a domestic worker}

The repetitive and physically exhaustive tasks like scrubbing utensils, washing clothes and mopping floors in several homes are routine tasks performed by domestic workers. The workers resent not only the dirt and grime that they deal with daily, but also the low appreciation (either socially or materially) that they encounter on the job. Irrespective of their age or physical condition, the workload remains as heavy as ever. Exhaustion, muscle aches, sore limbs and various illnesses contracted through work seep

\footnotetext{
${ }^{1}$ One Indian Rupee is roughly equivalent to 3 Canadian Cents
} 
away the strength of the workers. Many of the workers reported how they force their sore limbs to function at the end of the working day. The strain of having to work for multiple employers, each with their different expectations and demands, also creates tension among the maids. Sometimes the verbal abuse suffered at the hand of the employers within the privacy of the employer's home generates feelings of frustration and helplessness among the maids. As one maid expressed it, "For how long can I stay with quarreling with them especially since I have to work in their houses?" She felt powerless by her status as an outsider in the family, to continue with her struggle to get what she perceives as due to her. She is aware of the fact that despite her efforts to the contrary, she does not retain the ultimate control on her labour as a worker in a 'low skilled' and intensely competitive sector.

However the continuation of the workers in this occupation and the growing competition are indicative of the fact that the workers do not allow their negative sentiments to cloud their practical considerations. One of the common refrains encountered during fieldwork was, "I have to do it to allow my family to survive." The workers view their sufferings as sacrifices done for their families. Their acceptance of the hardships of the tasks is tempered by their satisfaction in fulfilling their responsibilities towards their families. Another aspect of the work from which they draw satisfaction is the bonds of friendship established with co-workers. Similarity of the situation at home and places of work binds these workers together. Although growing competition in this job is threatening to sabotage these relationships as one group replaces the other at the employer's residence, there is still a lot of cooperation evident as they create networks to exchange news, travel and share space at work sites, platforms and trains during the work 
day. Relatives and friends introduce new women to the profession and to prospective employers and try to stretch their kinship networks at work places.

\subsection{Conclusion}

Paid employment as a means of empowering women in India needs to be looked at critically in the light of the insecurities and vulnerabilities from which they suffer as workers, especially in the unorganized sector such as domestic service. The everyday experience of women as the principal and sometimes the sole income-earner in the family refutes the claims of a widely prevalent social practice which regards men qualified for this role, thereby leading to a gender differentiation in the wage structure. As inheritors of such unbalanced arrangements in society, the domestic maids need to constantly negotiate and readjust their identities as exploited workers. In the absence of assurances of protection for their labour power, the domestic maids need to adapt various means of resistance, ranging from counter claims as poor women, responsible wives and mothers, dependant on employers, to covert means like ticketless travel and unannounced holidays. However the persistence of these women in this sector, despite the disadvantages, reflects the lack of alternatives that they encounter in the other avenues of employment which are shrinking further. The reluctance on their part to take up home based work is partly due to the very small returns from such work and also because of the heavy burden of housework from which they have no escape even after gaining outside wage employment. This is the situation that I further explore in the next chapter wherein I examine the roles in their homes, which is an extension of my investigation into the 
nature and extent of value attached to the labour of such working class women by the Indian society. 


\section{Chapter 7}

\section{The 'Unconventional' Family: Women's struggles within the family structure}

Power is exercised in manifold ways, where conflict may be observed and where it is absent through 'control of the agenda', such that issues which potentially threaten the powerful do not become issues which must be decided (Palriwala 1990:41 in elaborating Lukes's concept of power, 1974)

The study of the inner functioning of families continues to remain a focus of research in empirical studies so as to establish the immediacy of the context which informs women's quality of life and also to gain insight into its inner complexities as a microcosm of larger societal intricacies. The family is often considered to provide the basic unit to an individual to meet his/her socializing needs. It also helps to explore and locate the broader social structures involved and their implications in particular instances. As a primary articulator of kinship ties, the family both introduces and imparts instructions on the prevailing norms of entitlement within and beyond its borders. The norms relate to key issues like inheritance of property, competing claims over food and nutrition, health care and education. They also extend to the more intangible realms of authority and decision making (Palriwala 1990:16). However the presence of varied adaptations and dynamics in the formation of familial borders, identity production and lived experiences (ibid) should alert us to the possibility of the indeterminate nature of the end results which is mystifying with its contradictions and subtleties of expression.

In West Bengal as anywhere else, a reading into social structures, culturally determined normative modes of actions and behaviours and value systems nurtured by it, may be used to gain an understanding of the critical roles that they play in shaping the individuals of both the sexes at both the level of the family and the attendant conditions 
in which they are embedded. There is need however for such an exercise to be sensitive to the gender power differentials in existence and the effects that they have had on the perceived and inner rationale which conditions the thoughts and actions of the actors. This is not only because of the fact that social dictums, perpetuate the inequities suffered by women but also silences dissent by incorporating her within the inner mechanisms of the body dispensing the norm. This aspect of women colluding against their own sex and thereby reproducing subjugation needs to be attended critically (Palriwala 1990:42).

There has been an enduring trait in research studies to conceive of the family as the medium through which women access resources to fulfill their needs. This has also been the underlying principle which has dictated the limited initiatives taken on behalf of the state to address the needs of impoverished sections of the population, a large number of whom are women. State directed welfare schemes have been channeled via family counts to the ultimate intended recipient, the women in the family. The perception of the family as the best guarantor of women's needs have informed such conceptions as women often subsume their interests to that of the household. The larger society is often presented as a greater threat to their security and interest so as to extract their subservience to the immediate family which projects itself as a champion of her cause. But gradually newer studies have come to light which have re-explored the complexities and power differentials among the members which have an ultimate bearing on their particular allocations and positions within the family structure. The altruistic function of the family where the head of the family supervises an egalitarian distribution of pooled resources so as to benefit all its members (Jose 2003:416) has proved to be illusive on closer inspection. As pointed out by Sen (1990), 
Models that eschew the problems of conflict within the household miss something quite central to an understanding of the household as an institution (Sen 1990:72 cited in Jose 2003:415).

Another framework often used to study familial settings is based on the bargaining power of the individuals constituting the family (Jose 2003:409). Drawing on the means provided by Game theory ${ }^{1}$ and Pareto efficiency ${ }^{2}$, this framework of family study implies that threats of non cooperation can be used by members to bargain for resource allocation and labour distribution that are available at the level of the family. The arrangement is precipitated by the fact that the loss due to non-cooperation far outweighs the losses that the individual members may suffer from, when they agree to cooperate (ibid). However the difficulty of implementing such models in the Indian context is that there is an absence of proper provision to take into account facts like societal values and norms as they are applied to members belonging to the opposite sex and the roles that they play in empowerment or disempowerment. As pointed out by Jose (2003) in the Indian situation, where the women's interests are subsumed within the family's welfare needs, there are considerable chances of a blurring of the boundaries that exist between the two (i.e. between the family and the women) and bargaining rules per se, become inapplicable (Jose 2003:419).

Practices like patrilineal descent, migration to the husband's household in the post marriage period, the near absence of women's rights over paternal property, the practice of dowry, low participation of women in educational attainment and wage work, are just a few of the multiple factors that restrict women's capabilities to participate in the bargaining process as free agents to safeguard gender rights. In such a situation, bargaining becomes a misnomer as the end result may just be compromise against other

\footnotetext{
${ }^{1}$ Game theory is concerned with how rational individuals make decisions when they are interdependent (Romp 1997:1)

${ }^{2}$ Pareto Efficiency is obtained when no individual can be made better off without making someone else worse off (Romp 1997: 4)
} 
less attractive alternatives (Sen 2005:242). The unequal distribution of power in such bargaining situations within the family is reflected in the choice of that solution among the whole gamut, which may have some absolute gains for all but relatively greater benefits for the powerful male members of the family (ibid:240). In such situations women have only limited scope of maneuvering and expressing subtle dissent as they bear the unequal burden of activities such as housework, childcare and cooking irrespective of their outside responsibilities as workers in the paid labour force. In the absence of any state intervention to ameliorate problems resulting from conflicting demands on their time and labour, and in circumstances of impossibility of hiring external help due to financial constraints, they resort to cooperation in the larger network of kinship and familial ties. Women in their diverse roles as daughters, mothers, motherin-laws and sister-in-laws provide assistance to each other. Drawing upon the lived experiences of the domestic maids of Kolkata, a closer look is taken towards this aspect of their lives.

This chapter has been divided into four parts and each part individually examines the power struggles that are fought out within the structure of the family, which is generally not evident when we consider it as a united entity. The contention is to show how labour and resource allocations remain disputed and vulnerable to changes within the family structure as reflections of the macro economic processes in which they are embedded. The first part deals with housework and the second with childcare. In each of these two parts analysis of the lived experience of the maids brings forth the conflicts that arise within the family, surrounding these issues, and the outcomes that follow. The third part of the chapter deals with the maids' experiences and roles as daughters and mothers 
in producing as well as opposing gender normative behaviour as friction points within the family. In the fourth and last section of the chapter, an analysis is made on the basis of narratives provided by maids about the emerging trends of financial resource allocation within the households of the maids.

\title{
7.1 When neglect becomes routine
}

Housework and childcare are two vital reproductive social functions that women undertake. The domestic workers whose occupational profile requires long absences from home face great difficulties in fulfilling these responsibilities. In this section I look at the compelling evidence of the unequal burden borne by the women in the family which may sometimes be at the cost of personal interests which they are powerless to protect.

\subsubsection{Housework without pay}

Yamuna is a middle aged woman who works as a part time maid in four houses.

Here she describes the housework that she has to cope with when she returns home.

\begin{abstract}
I return home at 6.30-7.00 in the evening. I go home and sweep the floors, fetch the water, go to the market, clean and prepare the vegetables and then start cooking. By the time we finish dinner, it is almost $10.30-11.00$ in the night. Sometimes my sons go to the market. My daughters used to help but they are now married. My husband (a van rickshaw driver) helps me sometimes. But sometimes he does not find time as he says, he has to carry passengers. You know in the village the men get drunk. When they are drunk they will not help you a bit.
\end{abstract}

Sathi, an elderly maid, when asked about any assistance she received at home in housework, had this to say

My husband never used to help me. But my son and daughter-in-law and my grandchildren who are also grown up now, help me out and get worried when I am late in going back home.

In another instance she say 
Previously I used to cook after going back home. My husband did not use to do any work. In my absence my elder son used to take care of the housework and his younger siblings. I had two daughters whom I got married off. However the year I got my son married, he started living separately from us. So finding no alternative, I married off my younger son as well. That solved my problem.

Malati is a young maid who works in six houses. This is how she described her activities on returning home.

\begin{abstract}
My mother-in-law cooks the midday meal while I take care of the dinner when I come back. After returning home I change my clothes and freshen up. After that I do the cooking. My sons then return from attending their tuition classes. After that I serve them food and after that I have my own food. If I miss the train and am late in returning, my husband will question me about where I have been. He is a drunkard and is suspicious of my behaviour.
\end{abstract}

Mitali is a middle aged maid who works in ten houses. She returns home late and has to cope with housework after that.

Before I come out of the house in the morning, I clean the house, wash the utensils and make arrangements for the cooking. The males in the family then take care of the mid day meal. Sometime they need not cook when there are left over from the previous night. In the evening I reach home at around 8.30 if the trains are running in time. If there are some delays then I reach home around 9. Previously when my daughter was present, I did not have to do anything after going home as she took care of everything. Now I have to do the cooking and everything else. My sons do the shopping and fetch the water. By the time I go to bed it is almost 11.30 in the night.

The different accounts by each of the individual maids provide a variety of insights as to the gendered nature of this task. It is apparent from their accounts that the long hours of work create situations of strain which definitely have an effect on their health and wellbeing. As had been pointed out by Swaminathan (2004:83) in her study of the familial work burdens of female garment workers in the Madras Export Processing Zone (MEPZ), these women, in their efforts to concurrently occupy multiple spaces, have to consistently negotiate their limited store of energy among the various tasks that need their attention so that they often stress themselves to the point of exhaustion. The multiplicity of response that such an adverse arrangement has evoked requires a closer examination. 
Yamuna's account of her housework shows her consciousness of being a victim to the system. She specifies all the tasks that she needs to take care of, before she can start cooking. She is aware of the late hour after which she can retire to bed. Although she does not take direct action to counteract this exploitative situation, she certainly expresses her discontent. She excludes her husband from the list of persons whom she considers as her assistants in housework. Her critical thinking casts doubts in her mind and she is not entirely convinced by her husband's plea to shirk housework by providing the excuse of his work. She alludes to the suspicion which is almost a conviction in her mind as to what she perceives as the real reason behind her husband's non-cooperation - his drinking habit. Widespread societal norms in the village, where such situations are commonly accepted, has perhaps muzzled her discontent as she does not seem to be able to think of a better alternative within the limitations of her circumstances.

Sathi, who faced similar problems, is emphatic in denying her husband any role in the housework. All three women, Sathi, Malati and Mitali have relied upon the help of another female relative, to take care of the housework in their absences. Their engagement in outside employment has not had a perceptible influence in elevating their status in the household as they, in the capacity of females, are still considered primarily responsible for the housework. The only male participation is seen in the area of fetching things from the market and retrieving water, two tasks which are considered to be more conducive to the masculine image than other types of housework (Ramu 1989:121). Thus, although poor males may be as disempowered as poor females in the outside world of work, within the confines of the family, males have greater power provided by society, religion and the state which allows them to deny their responsibilities for housework 
(Banerjee 1991:307). They only take it up when no female relative is present in the house, for example in Mitali's case. Such a type of distribution results in enormous work burdens for the females. Increased hours of work, both inside and outside the home as well as long journeys to work, have a debilitating effect on both their mental and physical well being. Many of them expressed reservations about introducing their next generation to outside work. Drudgery of the 'double burden' is one important contributing cause for women to view outside employment unfavourably especially if the remuneration does not bring any personal rewards for them, a finding which gains support in similar observations made by Agarwal (1988a:18). Although they privately denounced the elder male by blaming their bad habits for their non-cooperation in housework, publicly they remained silent as established social norms will take a negative view of the wife who allows her husband to share in housework (Savara 1986:106, Ramu 1989:129).

\subsubsection{Childcare provisions}

Similar to housework, childcare is another area of concern for women especially since glorification of motherhood is ubiquitous in India (Krishnaraj 1995:35). Like housework, it is considered to be the sole responsibility of women, with the state considering it to be the least of its priorities. Although attainment of the status of mother may not result in enjoyment of extra privileges for women, it is considered to be a necessary appendage to the fulfillment of their femininity. This accomplishment is achieved by women at the cost of sacrificing their own needs and aspirations (ibid). Women, irrespective of their working status, are the principal providers of childcare in the household (Ramu 1989:103). The mother is held liable to provide care and is 
considered selfish in the case of a lack of proper nurture for the child, whatever her other obligations may be (Bhoite 1987:40). The responsibility of the father remains confined to broad general areas of concern like health, well being and scholastic success while the mothers are in charge of every other aspects of childcare, namely bathing, feeding and looking after the other needs of the child (Ramu 1989:104). The mother often carries the child with her to ensure constant supervision (Bhoite 1987:40). In the case of domestic maids, the problem of childcare requires special adjustments. Due to their long work hours and tiresome journeys which cannot be easily withstood by young children, they have to be left behind at home. But unlike housework, which can be postponed and attended to during the latter part of the day, childcare requires a different solution. Even children who are grown up enough to be able to look after themselves, require parental attention. Again in the absence of the state and the elder male's cooperation, women adapt diverse means to find 'acceptable' solutions for such problems, the main help coming from elder children especially daughters and other kinship ties, as the following accounts suggest.

Jaya has four children and has joined the profession of domestic work about ten years back. This is how she recalls coping with her childcare responsibilities.

When I had started working, we already had two children. Then I took a break when
my other two children were born. I joined work only when they were a bit grown.
My aunt-in-law and my grand mother-in-law looked after my children when I was
away. They have both died about four to five years back. Once my children started
to walk, they looked after themselves as there was not always somebody to look
after them. Rita is a young maid and mother of four children. She has been working for three years now. She expressed dissatisfaction with the childcare system she has at home.

Yes, I face problems. Their father is now at home because he is ill. Otherwise he does not stay at home. I and my two elder daughters take turns to come to work. While one of us stays at home, the other two come out to work. The one who stays 
at home sends the younger ones to school. They go to school due to the attraction of the mid day meal provided in primary schools. That too they will not go everyday. Sometimes they remember to go while at other times they go off to play. These are my two sons. One is five while the other is six years old.

Malati is another young maid who has two sons and has been working for ten years now.

This was her response about her strategy for child caring.

When I started working after marriage, my elder son was five and a half years old while my younger son was one year old. My elder son used to live in my parental home where my sister used to look after him while my mother-in-law looked after the younger one. My elder son looks like my husband and is dark in complexion. So nobody in my in-laws place liked him very much. My younger son had a fair complexion and was a handsome baby. So everybody loved him in the house. Now both of them are grown up and can look after themselves while I am away. So they both live with me now.

The above accounts reveal how, in the absence of proper childcare facilities, working women have to devise diverse means to take care of their children as their work responsibilities necessitate them to be absent from the house for long periods. The strategy adopted by Jaya to join work only after her children are a bit grown up is adopted by many maids. Although adoption of this approach may apparently provide relief to the household, the drawback is that for this entire period the women are denied any monetary support as no maternity allowance is available in this sector. The standard of living of the family suffers dramatically where the woman's income is the primary if not the sole source of earning. This induces many women to join work as quickly as possible. Both the mother and the child suffer as a result. While the child suffers from lack of nutrition and care, the mother suffers from the agony that such separation induces.

The second strategy that is widely resorted to by working women and also commonly found among the maids is to depend on family and kinship ties. While some maids have acknowledged the help they received from mothers, mother-in-laws, fatherin-laws and sister-in-laws, others have mentioned the contributions of daughters, sisters, neighbours and sons. While such help is eagerly accepted in the event of the absence of 
better alternatives, it cannot be denied that this too is not the best solution. As demonstrated by Saradamoni (1992:175) there are several disadvantages involved in such arrangements which are difficult to overlook. The first constraint relates to the age of the woman who provides the assistance. If she herself falls within the working age group, then she would have to withdraw her assistance after a time as otherwise her economic losses build up. Again, relatives from the women's family can provide assistance only when they live near by. This may not often be the case, as girls tend to be married off to distant villages far away from their places of origin, making it difficult for them to seek assistance from their own relations in times of need. Again, mothers of married girls cannot stay for long in their married daughters' residences as local social norms are derogatory of such practices. Also she may have her own responsibilities at home preventing her from staying at her daughter's place for an extended period. Although unmarried sisters are another potential source of help, again they were less mentioned due to the norm of early marriage. Another explanation is the fact that unmarried girls who have reached or are close to reaching puberty have much of their freedoms curtailed and cannot stay for long outside their homes even at a relative's place. The only way they can help their married sisters with childcare is if the child is sent to stay at the woman's paternal home as Malati's case demonstrates.

These problems are not present in those cases when the kin from the women's married ties are willing to help. But a word of caution needs to be spelt out here as many a time these kin are elderly in age and cannot provide more than overall supervision. In such circumstances, the child is left on its own for prolonged periods of time and has nobody to look after it. Some incidents of children drowning, burning or being bitten by 
dogs were reported by the maids during the interviews. Such news is dreaded by the mother when she goes out to work and many a time her work day is interrupted when she needs to rush back home when such news reaches her.

The most common arrangement that is resorted to, however, is where the older children are vested with the responsibility of looking after the younger siblings. It is these children who are the most poignant victims of the irresponsibility of the state and the society when they deny these women a better alternative childcare system (Saradamoni 1992:175). Often these elder children, who are most often girls, are obliged to skip their own studies because of the overwhelming responsibilities that they bear, thus perpetuating and stretching their impairment to the next generation (Hensman 1999:181). As evident from Rita's narration, the daughter who is left in charge of the younger siblings acts as a surrogate parent and is also responsible for the housework. It is not always possible for her to ensure that her younger siblings go to school as there are multiple tasks that she has to contend with at the same time. This child is, in turn faced with many losses, the starkest of which is lost childhood.

Another less apparent effect which results from the scarcity of childcare provisions is that when the mother returns exhausted from the day's work and has a lot of housework to complete in the rest of the time available to her, childcare often becomes too much of a burden for her. Many a time her patience gives way and she finds herself incapable of coping with the demands of childcare leading to an alienation from her children. Some of the maids reported how they regretted the fact that they could not help but let their children fall asleep with empty stomachs when dinner was late. Many of them valued their holidays for affording them some free time when they could properly 
bathe and feed their children and spend time with them, something that they missed doing during their workdays.

\subsection{Daughter and Mother}

The place of a daughter in a Bengali family is an ambivalent one. While a strong prejudice favours the son irrespective of his other qualities, the daughter is looked on as a precious liability but a liability no less. The partiality to the son and correspondingly to the male members of the family originate from a number of sources. The male members are considered to be the bearer of the family line in the role of the son while in the role of the father it is he who introduces the child as his progeny to the outside world (Fruzzetti 1982:26) thereby linking the ancestral and the future generation through his being. A daughter on the other hand passes out of the ancestral chain on getting married, leading to the severance of ties with her natal family materially as well as symbolically. She enters new kinship ties with her husband's family upon marriage, though not in her own right but as the bearer of children who will carry her husband's line forward (ibid:124). Again, while the presence of unmarried daughters in the house attracts social ridicule and apathy, love marriages are not considered fit for emulation and are rarer in occurrence (ibid: 30 ). Thus early marriage of the daughter is advised to prevent her from making 'rash' decisions about giving herself to someone unsuitable which can harm the family's prestige and make it vulnerable to social stigma (ibid:31). Early marriages of girls aged between twelve to sixteen years and arranged by parents are therefore the most preferred and prevalent form of marriage in rural Bengal. Such fears for social stigma on account 
of unmarried daughters were found to be true among many of the maids especially since their long absences from home meant that they could not always supervise their children.

After marriage most girls left for their new abode with their husband's family. In such a circumstance, the daughter in her unmarried status in her parent's home is considered to be a temporary member. After marriage she becomes the member of a distant family who benefits from her labour and accomplishments (Dreze and Sen 2002:161). The son on the other hand stays in the family home and is considered to form an asset for his parents in old age (Rani and Unni 2004:121). This forms the groundwork and rationale for the difference in the treatment meted out to sons and daughters within the framework of the household.

In situations of adequate resource availability, this may not pose a problem as parents can afford and choose to spend liberally in the upbringing of their children whatever their sex may be. However in those families where resource restrictions are critical, considerations of these relative advantages and disadvantages play a crucial role in resource allocation. Female children lose out for a number of reasons in competing with their male counterparts. An overwhelming number of maids mentioned their inability to learn newer skills as one of the chief factors that have prevented them to take up more remunerative jobs. A large number of them cited illiteracy as a chief reason preventing them from realizing their potential. Only three among the twenty maids interviewed reported receiving any education at all. Those who received some education did not go beyond the primary level (class V or fifth grade, in Kolkata, India). One maid was vociferous enough to suggest that her illiteracy made her blind despite the fact that 
she possessed good eyesight. Her sense of powerlessness was acute. She felt betrayed by the incompetence that such a state bestowed on her.

While some of the maids blamed their parents especially the irresponsibility of their fathers who had failed to provide them an education, others felt that an anti-female bias in society was more to blame. However a thing to note is that the bias that they detest in their own life is allowed to be perpetuated in the next generation, although in a revised form but nonetheless clearly evident. While all the maids reported at least some effort to make their sons literate and to support their education up to the secondary level at least, only half of the proportion made the same effort for their daughters. In discussing these issues and attempting to analyze them, many of the maids referred to their financial weakness, the prevailing social norms and the particular situations in their homes to justify it. While the mothers aspired for a good career for their sons, for the daughters it was to give them in 'good' marriage.

For reasons pointed out at the beginning of the section, it was considered necessary to educate at least the son to some extent. The investment in the education or skill for the son is considered necessary because he is required to earn a living when he grows up, not only for himself but also for his wife, children and old parents, a view that is widely held in social circles (Sundar 2001:20). This expenditure on a son's education is considered to be a capital formation that will benefit and provide fame to both the past and the future generations and help them to progress in the social rung through his accomplishments. Thus there is a tendency for sons to be introduced to some form of schooling. Thus when male children drop out of school it is more often the result of their own will rather than any family obligations, an observation which finds support with 
Kulkarni's (1996:35) findings where she comments that there is relative freedom of boys to drop out of schools and avoid family responsibilities to a greater extent compared to girls even in low income households.

In the case of daughters, a whole set of new considerations comes into play. As stated earlier the primary responsibility of the parents towards the daughter is to give her in a 'good' marriage (bhalo biye). A 'good' marriage means marriage in a family where all her needs will be provided for. This meaning of good marriage excludes chances of her having to work outside for a living and if at all that is required, it will be in a family farm or in an establishment run by the family. This is an instance of aspiration of high class status (on an economic basis) for their daughters. Many of the maids expressed the satisfaction of marrying their daughters into such families.

Giving their daughters in marriages however required a sound financial investment in the form of dowry. Although initially practiced by the higher castes and classes, it has gradually infiltrated down to the lower castes and classes of the society (Gupta 2002:1747) despite it being outlawed in India by the Dowry Prohibition Act 1961. Dowry involves the giving of non reciprocated gifts in the form of cash, jewelry and other capital goods by the bride's family to the groom and his family (Fruzzetti 1982:111). In tracing the origin of dowry Kishwar (1993:10) contends that in societies where land is scarce and labour is cheap, the land gets divided up among the powerful in the society i.e. the males. Women who are dispossessed as a result are either rendered as burdens for their families who can pass them on in marriage to other families but only after paying a compensation for it in the form of dowry. However the modern connotations of dowry have changed to some extent. With the consumer culture creeping 
in, dowry is being used as a method by the groom's family to build up its capital at the cost of the bride's family through the institution of marriage (Kalpagam 1994:54). Thus families with daughters exhaust their life savings in order to pay for dowries. Again sometimes they have to make large debts at high rates of interest which they gradually pay off with their monthly earnings. Most of the maids reported that they have to pay dowries for their daughters in marriage for which they have to save money from their salaries or take up additional work to pay off debts which may take years to pay off. They are therefore less inclined to incur additional expenses for their daughter's education. Also, educating the daughter will mean looking for a groom who is educated to a higher level, an observation also made by Dreze and Sen (2002: 161). This means added expenditure as the more qualified the groom is, the greater is the amount of dowry that will be charged by his family. Also in areas where male educational levels are low, it may be difficult to find a suitable groom for a highly educated daughter. Again there is a link between the prevalence of early marriage and dowry payments which has a negative impact on their educational aspirations. The dowry payments are less for younger brides as they are believed to be at the height of their fertility at younger ages which brings down their dowry amounts (Gupta 2002: 1747). Such early marriages prevent many daughters from pursuing higher education.

However in one convoluted way the practice of dowry has helped the cause of the daughters. As was evident from the conversations with the maids, many were averse to sending off their daughters to work as full time maids for employers. If it became public knowledge that the daughter was engaged in such an occupation before marriage, it was likely that this would be considered a negative quality and consequently dowry demands 
would increase in such instances (because of the stigma of having worked outside the home). This acted as a disincentive for the maids to send their daughters for such work. On the other hand during the research, some evidence came to light which showed that although the daughter was sent to work at an earlier age, she was withdrawn from the work force on reaching puberty. In still other cases the younger daughter was sent to work to help the mother to accumulate the dowry amount she would need to pay off for the elder daughter. Nevertheless these instances of sending young daughters to work were few among these maids and were growing fewer by the day. Most of these maids joined work after marriage and after the birth of at least one child.

Apart from dowry, other factors were also present which prevented the daughters from pursuing education to higher levels if at all. As pointed out in previous sections, the outside engagement of the mother and the non-cooperation of the father meant that housework and childcare were two areas in which children, especially elder children, were required to participate actively. Although children of both the sexes were involved in these tasks, generally girls far outnumbered boys in such tasks. A perusal of the reasons behind such patterns will also shed light on the power dynamics between the two sexes operating within the household.

At the early stage when all the children are young and on a relatively equal standing within the household, the elder of the children, irrespective of the sex, takes up the responsibility of looking after the younger siblings. But gradually as the children begin to grow up, the family has to make newer adjustments to the emerging power structure. If the elder sibling is a daughter, she continues in her role as the principal guardian of the children in the absence of her parents or other elders. However if the 
older sibling is a son, he gradually starts to give up his domestic obligations. A greater engagement with the external world, as permitted by society for the male, allows him to build up a peer group outside the home. This helps to awaken the male ego in him. Domestic work is not considered conducive to this image. Society accepts it as an expected transition. Many of the maids reported how their sons at younger ages helped them out, which however was withdrawn as they came of age. Most of the time it was passed on to the sisters.

The female child after reaching maturity is discouraged from forming social groups outside, which effectively limits her horizon. Staying outside to work after dark, traveling to distant places without chaperones, talking to unknown persons, especially males, are strictly discouraged (Sundar 2001:20). As bearers of family 'honours' such sacrifices are sought to be inculcated in the girls early in their lives. In such cases daughters who shun outside life are made to feel more and more dependent on the household to which they devote a large part of their time. Working mothers like the maids who are themselves victims of such systems do not discourage it as they themselves are desperately in need of such help to share the burden of housework and childcare which awaits them on their return from work.

Nonetheless it would be wrong to contend that domestic maids in their capacity as daughters and mothers have remained silent spectators who have not made an attempt to alter the gender segregation suffered by their sex. At least half of them (i.e. ten out of twenty) made it possible for their daughters to attend school, something which they had been denied by their parents. This is no mean accomplishment, either for the mothers or the daughters as it has been achieved against the heavy odds of serious financial 
constraints, heavy work loads and scarcity of guidance which first generation learners with restricted outside contact face.

A few of the mothers expressed their desire to continue with their daughter's education as far as they could. They resorted to several strategies in order to postpone the marriages of their daughters even under the pressure of spouses or in-laws, as they knew it would mean an end to the little freedom and access to skills that their daughters still enjoyed. Often they would use the burden of housework as a device to postpone the marriages of daughters. Lack of alternative arrangements sometimes forced their husbands to acquiesce to their demands. Again, in other instances, they would not reveal the amount of savings that they have made to be given away as dowries during the marriage of daughters. They would deliberately quote reduced amounts and buy time for their daughters. In other cases they would use the excuse of lingering debts acquired through the marriage of previous daughters to postpone marriage of the younger daughters. The time gained in these ways, although short, provided the mothers some control over the fate of their daughters which their own mothers lacked.

On the other hand, the mothers expressed their reservations about continuing to focus their hopes on their sons as supports for themselves in old age. The irresponsibility of their husbands in carrying out the duties of husband, father and son has disillusioned them. The disintegration of the joint family which has infiltrated even rural areas has made them apprehensive of continuing to harbour absolute faith in such arrangements. Most of them therefore hoped to continue in their profession for as long as their faculties would permit so that they could build up a reasonable savings to cushion their retirement 
years. They look upon their professions as a necessary evil which have made them more perceptive of such social changes and also provided them with a means to fight it.

\subsection{The politics of control}

The apportionment of available resources in the family and the allocation of positions among the different members posit ample scope for negotiation and renegotiations which has an ultimate bearing on the power structure inside the family (Devi 1982:48). Among the various competing origins from which power is derived, a significant amount of conflict revolves around the financial strings of power as this is the principle means through which rewards are gathered and labour is controlled. However in order to gain a broader comprehension of power there is also need to attend to its other aspects. This is provided by studying the methods of disposal of the finances. While the first area deals with power production, the second one deals with its application on the ground. There need not be a close correspondence between the two as, in many households, different members may exercise control over different areas and to different degrees.

The participation of women in outside employment is often considered to be beneficial to the enhancement of their status as it provides them with some degree of autonomy in pecuniary terms. However, within a broad framework of patriarchy where female rights and freedoms are curtailed to a large extent, if the financial earner is a female, there may be many hindrances against her taking an active role in deciding its expenditure. In such cases where the adult male in the family, as an accepted social norm, is vested with the authority to dispense of family finances according to his discretion, it 
requires covert manipulation on the part of other members to establish or retain influence over such decision making. The need for such maneuvers is appreciated by the actors as open challenges can provoke complete dissolution of hard won freedoms. The following narratives serve to disclose the subtle politics that underwrite the tussles over finances and through them over power, within the confines of the household.

Malati relates here her rationality to depose of her salary in the way she does. Her husband is an alcoholic and occasionally works as a casual agricultural labourer

Out of my entire salary I give Rs. 600 to my husband for family expenses. Out of the rest of the money I make some savings in the post office. I also need to spend some amount to pay the tuition of my two sons. I know that I need to save for the future of my sons and myself. If I am ill, I know that my husband will not look after me as he is a drunkard and never gives me any money whatever the need maybe. I will also need to eat when I will not be able to work anymore.

With the money that I give him, I see that he sometimes uses it to shop for the family's needs; sometimes he uses it to buy a drink for himself. At those times we have to make do with rice and nothing else. But whatever he does, I have to hand over that Rs. 600 to him after receiving the salary. Otherwise he will create a lot of problems. He will curse me or beat me up or prevent me from coming to work. But if I pay him off that amount, I can be at peace and spend the rest of my money according to how I want to, in shopping for my house or for my sons or whatever.

In another instance she is talking about what happens when her salary increases after working for sometime.

Now I do not let my husband know about these increases. I also sometimes earn some extra money, doing extra work but I never let him know about it. I spend that money for my family but from my own hands. I do it as my husband is not a good person.

Kanak discusses here her method of salary disposal. Her husband and son drive rickshaw vans on the village roads.

I give my salary to my husband and son to take care of the family expenses as I stay outside the house for long periods. I have to keep everybody pacified. However about two years back, I had opened a post office account where I need to pay Rs. 500 after every three month. The last two months I have not been able to pay anything, but this month I am determined to pay as soon as I get my pay.

Sushila is the sole earning member of her family.

I give part of my salary to my husband which he uses to make family expenditures. But from the expenses I can make out what he has been doing with the money. The 
rest of my salary, I use to make a saving. My husband was not willing. But I knew I had to save to get my daughters married off. Nowadays you need money to marry off your daughters.

Each of the above accounts suggests the multiplicity of conflicts that ensue within the family in a bid to dominate the distribution of finances. The friction results from competing interests. As each party tries to monopolize the distribution, they utilize their strengths to dominate the others into subjugation. Each one tries to project as given, social norms and family values which reinforce their positions as justified. Quarters of struggles are surrendered for quarters won. In such situations, victories and losses cannot be measured in absolute terms as such measures fail to capture the diversity and the intensity of the struggle. Relative and temporary victories are more common.

As Malati's account reveals, she realizes the precarious hold that she exercises on the household finances vis-à-vis her husband. Her ability to work outside and earn a wage is the source of both her strength and her vulnerability. Income from her profession allows her to exercise some control over household expenditures. However the tenacity of this tie can be stretched to a breaking point and beyond, if she does not agree to comply with the rules laid down by her husband. She has experienced the threats of violence and torture on her mind and body. She cannot just ignore it as a result. Society's acceptance of this normative power of males as husbands to command and discipline nonconforming behaviour of their wives or sisters or daughters, if required through the exercise of force (Kishor and Gupta 2004:698), subsumes this reaction on her part. Social norms which negate women's rights against infringement and abuse over her physical and mental faculties, displays the gender segregation biases which underlie their evolvement. While Malati's husband can use force against her in cases of non compliance with his terms, she can only accuse him as a drunkard. 
Malati is not alone however in charging her husband as a 'drunkard' and 'not good'. Other women and other maids have joined her in this accusation. While some have called them 'lazy' others have used terms like 'spineless' and 'ill-tempered'. These women have therefore joined voices to make a forceful statement against accepted norms which are gradually making space within social discourse and public conscience. The voices are gathering strength and can no longer be dismissed as isolated outbursts.

Malati has therefore gathered a number of reasons to justify her decision to conceal the details of her salary from her husband. She has made a precise statement about irresponsible behaviour of husbands and what they deserve for it. She has argued to justify her actions from three perspectives, as a human, as a mother and as a wife. She knows that old age will seep away her strength one day and she will have to discontinue work. As a mother, she has sought to protect the rights of her sons against the sharp contrast of the unconcerned father. As a wife she has made a strong appeal against her husband who has refused to support her even in times of weakness and ill-health. She has therefore drawn upon this triumvirate of strong imageries to rouse the instincts of the society and sensitize it about her plight. She is confident as she knows that society cannot but notice with sympathy her contributions to her family in opposition to her husband. She has fewer inhibitions of projecting herself as a flawed wife as she portrays herself as a victim of circumstances. Thus upon drawing on Ramu's (1989:142) observation it can be surmised that she as an individual may possess a distinct image in her mind of an 'ideal' husband and wife, but her lived circumstances may enable her to ignore or disable her to emulate such an 'ideal'. 
However her experiences have taught her that social rules outside the household and inside the household occupy spaces which may not only display resistance to displace each other but may collude in unexpected ways that may eventually jeopardize her position. Her decision to cooperate with her husband's demands originates from this defence strategy that she adopts when she uses the financial resources at her disposal as a trade-off against her freedom in other spheres.

Malati's case is also important for study because it shows the differences in how the male and female perceptions vary in disposing the resources of the household in the best possible way. While the males spend a large amount on personal needs, denying the basic needs of the family, the female spends even the last shreds of her income on the welfare of the household.

Kanak has analyzed her position within her family from a slightly different perspective. Her son and her husband are co-earners in the family though she contributes the largest amount and most regularly. However her profession takes her away to the city where she has to spend long hours while her male relatives as van rickshaw drivers stay in the vicinity of the village. Both these factors have contributed to a role reversal in her family and the males feel threatened by such emerging power politics. She realizes it and tries to dissipate the tensions by using a portion of her salary to maintain a false sense of status quo. Her use of the word 'pacify', however, means that she is well conscious that the eventual freedom in deciding how to dispose her salary ultimately lies with her and it is her choice that she has adopted this means to dispose of it. She has kept the other part of her income which constitutes her savings under her exclusive control and is determined to contribute to it regularly. 
Sushila is the sole earner in her family after her husband retired from work after developing heart problems. Since she is the only income earning member in her household which consists of five members, namely herself, her husband and their three children, her family also experienced a role reversal between the husband and wife with its commensurate redistribution of power within the household. Though she admits submitting her income to her husband, her submission is partially symbolic as she closely monitors its disposal. The potential of a conflict that may seem just apparent here in the public eye has possibilities of adopting more substantial proportions in the private sphere of the household. However the differences emerge more openly from the shadows in the context of the savings made from the income. Sushila takes a more defiant and belligerent stand here as she like Malati before her, knows that this time she is fighting for the sake of her children. Her stand of being a responsible mother who needs money to marry off her daughters, she knows, will strike the right social chords.

One might expect patriarchal bonds of the society to maintain their stranglehold on the functions of the family and continue in their perpetuation of gender roles based on domination and subjugation. However on a closer look such an arrangement is affected by changes of time and conditions. As the maids have demonstrated in their lived lives, a distinct inference that can be drawn with Palriwala, (1990:41) is that even where women struggle against heavy odds and are clearly encumbered by prejudices held against them by society, there remains scope for isolated spheres where they bring their active agency to the forefront and decide for themselves. While in their own lives, the maids remain prisoners of their limitations, they speak out for the rights of their progeny whom they want disinherited from the deterrence that have obstructed their paths. 


\subsection{Conclusion}

Neoclassical models of families as welfare maximizing tools for all the members irrespective of their standing in the wider social, political, economic and cultural realms, have lent themselves to criticism in recent times due to the lack of its congruence with lived experiences. The variation in the bargaining capacity of members prevents them from acting as free agents who can best protect their own interests. Conflicts emerge from it but it is difficult to detect distinct outcomes as interests, priorities, options collide and coalesce providing the members with novel combinations and opponents. Burdens are shifted on weaker and vulnerable members, mainly females or young children resulting in exhaustion and strain. Children, especially females, are pressured to follow gender normative behaviour and roles and are denied access to education and skill training. Practices like dowry, early marriages and seclusion force girls to remain dependant on the household. Severance of ties with natal families after marriage results in denial of kin support and loss of confidence. Mothers, in general, act as colluding agents in the deprivation of their own sex under the aegis of social norms. However newer perceptions of mothers have questioned their own roles as they try to at least exercise more options for their daughters which were absent in their own. They have also disputed their husband's claims of unquestioned access over the financial resources of the family as their own contributions far outweigh the others. By dragging these issues on to the 
bargaining agenda, they have demonstrated the shifting equations of power within the family. 


\section{Chapter -8}

\section{In Drawing A Conclusion: Struggle, Resistance and Reconstitution}

Agency freedom must, in fact, include the freedom to think freely, without being severely restrained by pressurized conformism or by the ignorance of how the prevailing practices in the rest of the world differ from what can be observed locally...Informed and critical agency is important in combating inequality of every kind, and gender inequality is no exception (Sen 2005:25).

The commonality shared by development discourses pursued in global headquarters as well as in India's metropolitan cities is their failure to acknowledge the productive roles that women play in the economy and the society. The origin for such a lack of recognition probably stems from a misguided notion about the dispensation of responsibilities between the sexes. State plans are formulated visualizing men as the principal sustainer of their families while in actual practice, men and women share this responsibility and frequently it is women who bear it on their own (Heyzer 1994:17). In fact, developments imposed from above have often been accused of complicity in strengthening the structures of patriarchy in the garb of modernization (Mitter 1986 cited in Escobar 1995:173). Growing discontent and dissatisfaction at the failures of these 'trickle down' theorists to deliver the promised goods have resulted in the gradual escalation of counter movements among those who were ironically considered as targets of welfare in earlier initiatives. The growth of grassroots movements among women in third world countries like India has brought to the foreground the hitherto neglected role of women as agents of change. In many such instances, women had sought or were sought out as partners by non-governmental organizations (NGOs) to provide for a combination of everyday practices and organizing experience. These NGOs which operate at the grassroots levels, by the very nature of their 'decentralized' operations (visà-vis the state), have helped to give structure and legitimacy to this movement (Kalpagam 
2002:4689). Sometimes external agencies can provide the vital energy to an ongoing process of social change especially in those areas where women have a lesser say in decision making and are denied free access to resources and newer ideas (Sen and Batliwala 2000:19). Also, in situations where the struggle for empowerment has to be carried out at various levels simultaneously, for example the family, community, market and state, outside agencies with their greater experiences and networks can help individual women (ibid:20).

This chapter has been divided into four sections. In the first section I review the work of NGOs (involved in organizing the domestic workers) in different states of India and the issues that they are fighting for. In the second section I give a brief overview of two NGOs based in Kolkata, West Bengal that are playing important roles in empowering poor women. In the third section I try to build on the strategies adopted by these organizations by suggesting additional approaches and in the final section I look at a studied case whose failure carries valuable lessons from which NGOs can derive further understanding of the condition at the grassroots.

\subsection{Empowerment through organizations}

The role of NGOs, in organizing India's domestic workers to fight for their rights of recognition, has been in the form of a growing partnership that has started to make its voice heard to an expanding audience in civil society and government. A brief perusal of some of the highlights of this movement, located in different parts of the country, will provide a sense of the gathering pace of the movement and the victories and losses encountered in the process. 
On February $14^{\text {th }}, 1980$, an organization of domestic workers was founded in Pune, Maharashtra called the Pune Shahar Molkarin Sangathana (Pune City Domestic Worker's Association) (Government of India 1988:205). The immediate cause was a strong urge to launch a public protest against the harassment of a maid by her employer. A ten day impromptu strike was called, supported by seven hundred domestic workers, and this paved the way for the formation of the Sangathana. The organization, which has increased its strength since then, has been at work to draft measures to ensure better working conditions and wages for the domestic workers (ibid). The Sangathana has also actively intervened in disputes between workers and employers. In 2001, they announced a pay structure for domestic work including rates for different kinds of work, bonus, paid leave, extra wages for extra work, and worker gratuity in case of termination. They have also tried to restrict the maid's total working hours to eight per day. One of the most crucial feats of the Sangathana was the adoption of a resolution by the Maharashtra government on August 10,2000, recognizing workers' rights on the following issues:

a) One month of salary as a festival bonus for workers who had been employed for a minimum period of one year.

b) The employers to share the medical expenses of workers

c) An annual increment in salary

d) An annual paid leave of a fortnight for full time maids (India Together, Apr. 2004)

The National Domestic Workers Movement (NDWM), founded in Mumbai in 1985 , is the only NGO representing domestic workers working at a national scale in India, a country in which approximately fourteen million workers work as domestic maids. Its operation extends to eighteen states of the Indian Union, including Chattisgarh, Bihar, Andhra Pradesh and Kerala. It works with domestic workers, child domestic workers and migrant workers. On 23rd March 2003, domestic workers in Andhra 
Pradesh, under the aegis of the Domestic Worker's Movement, participated in a strike in Hyderabad demanding that they be included in the Andhra Pradesh Unorganized Workers' Act (Regulation of Employment and Condition of Social Security and Welfare) which would pave the way for the recognition of domestic workers as labourers, provide for their social security and medical facilities, and put a ban on employment of children in this profession (The Hindu, Apr.7, 2003). Again in Kerala, in early 2004, about 2500 domestic workers from four districts in the state had organized under the banner of Kerala Domestic Worker's Movement. Their membership in the organization has however antagonized the employers, who considered it to be the reason for militant attitudes among the maids (The Hindu, May 31, 2004).

The National Domestic Worker's Welfare Trust is another NGO involved in organizing domestic workers based in Mumbai, Maharashtra. It aims to provide justice and empowerment to workers in this sector. The programs pursued by the organization are abolishment of child domestic labour, crisis intervention with rehabilitation, providing legal and medical aid to the workers, and extending networks at the local, national and international levels (Global Giving, 2004). In 2002 this NGO together with HRLN (Human Rights Law Network), another Mumbai based organization, successfully filed a Public Interest Litigation in the Supreme Court of India. The demands put forward were for the installation of better working conditions for domestic workers, including holidays, paid leave, medical assistance, maternity benefits, provident fund benefits and issuance of identity cards. In November 2004, HRLN together with NDWM (mentioned earlier) and National Commission for Women (NCW) arranged a conference in Delhi, the national capital, to expose the terrible conditions of work faced by domestic workers, 
including at times physical and sexual abuse. However since the workers of this sector do not come under the purview of the labour laws, a special bill to provide legal recognition for the rights of the workers in this sector, was sought to be introduced, first before the state government of the western Indian state of Maharashtra and subsequently in other parts of the country. However after repeated stalling of the bill in Maharashtra, the future of the bill has grown uncertain (India Together, Nov. 2004).

Another Indian state in the southern part of the country, Karnataka, earned the distinction of becoming the first state in the country to fix the minimum wage for domestic workers in the range of Rs. 1800-2200 for eight hours of work per day (Deccan Herald, June 12,2004$)$. In this state, a notable NGO working alongside the domestic workers is the Domestic Workers Union. This NGO has been at the forefront of the struggle to implement the provisions of the Karnataka Unorganized Workers Bill 2001 (Regulation of Employment and Condition of Work). This bill has put forth the rights of the domestic workers to minimum wages determined by the size of the family they are employed in, along with leave and other benefits. The Union has also been involved in providing legal aid to domestic workers who frequently face false accusations of theft (Deccan Herald, July 6, 2004).

\subsection{Two grassroots NGOs in Kolkata}

Given the wide ranging and expanding movement of domestic workers in the other metropolitan cities of India like Mumbai, Delhi and Bangalore, I was surprised to find only a lukewarm response in Kolkata. I was able to locate only two NGOs working with domestic workers in Kolkata. With an intention to try and understand this lacuna I 
approached academics and NGO workers with this question. An explanation put forward is presented.

In cities like Delhi or Bangalore the wages for domestic workers are very high (compared to Kolkata). This is because the opportunity cost here is also very high as there are alternatives available like textile factories or in small electrical appliances factories...So the concept of piece-rate work has permeated from the boundaries of the factories to the homes where these women get employed. Here the demand for workers has gone up. In these more industrially advanced and growing cities of India the rates have become more or less fixed and are riding a rising curve than in Kolkata. Secondly the political party here is very tight. The political domination is present in every sphere. Here the same political party has been in power for a long time. But it has not been the same there. There the power is held by political parties which alternatively come to power. So there is an empty space. And hence there is scope for the groups to take advantage of this dynamism (Ajitava Roy Chowdhury, Personal Interview)

As commented above, two important factors seem to stand out to explain the limited response of the movement to organize domestic workers in Kolkata. On the economic front, the lack of a robust economy has limited alternate employment for those engaged in domestic work, thereby somewhat blunting the scope of their negotiating power with the employers. On the other hand, from a political point of view, the great length of time (twenty six years) in which the incumbent party has been in power, has become a factor which has worked against the growth of the movement. As pointed out by Sen (1999:349), the operation of NGOs in Kolkata are both "disliked" and "questioned". The CPI(M) party considers itself as the 'vanguard' of the organized worker's movement. The efforts of any other organization in mobilizing workers are looked on as interference. The NGOs in Kolkata therefore remain mostly restricted to a welfare and modernization agenda (ibid). The other metropolitan cities in contrast have experienced more frequent changes in government, thereby rendering the ruling party insecure enough to try and gain support of a wider electorate. The gaps created as a result of the uncertainty in the political sphere has provided a window for the growth of more empowerment-oriented NGOs in cities like Mumbai, Delhi or Bangalore (ibid). 
One of the NGOS that I worked with in Kolkata, called 'Parichiti' (in Bengali meaning identity), is actively engaged in the organization of women in domestic service. However this organization is in its initial stages (with limitations in experience, exposure and diffusion in the field). As it is the only organization of its type in Kolkata (working solely with domestic workers), I felt the need to study another organization which would help me further enrich my knowledge. This second non-governmental organization called Nishtha (in Bengali dedication) however works under a broader perspective of empowerment for women in rural areas. Domestic workers figured in their programs as only a small segment of the affected population. It was hoped that a simultaneous examination of these two organizations, separated in time of origin, scale of operation and location of bases, would provide a greater understanding of the context than would a singular perspective.

\subsubsection{Parichiti}

Parichiti is a young grassroots NGO which came into existence about two years ago. The express purpose of this organization is to mobilize female domestic workers commuting from the suburban areas to the city on a daily basis to serve middle class households. These workers find themselves in extremely vulnerable conditions as they have neither a minimum wage or fixed duty hours. Many of them suffer hunger and disease without treatment. Their work in the private sphere of the home which entails their invisibility from the public eye and their contribution to the smooth functioning of the middle class homes remains unacknowledged. Parichiti's project has therefore been to work towards organizing the domestic workers so that a collective effort can be made to 
improve the condition of workers in this sector, and to try to address their problems and make them more visible in the public sphere.

The organizational framework of Parichiti consists of six board members, an advisor and three office staff. Except for the office staff, all the members are volunteers. The advisor is a senior social worker who helps in directing the day to day activities of the organization. The present office of the organization is located at Purbachal in south Kolkata but it is only a temporary arrangement as plans are underway to shift it to a location close to their field of operation. This field of operation is located mainly in two railway stations at Dhakuria and Jadavpur in south Kolkata, where a large population of maids disembarks. The effort to shift the office is mainly aimed at making it more accessible to the maids. The NGO receives funding from The Global Fund for Women ${ }^{1}$ as well as from individual donations.

The programs that are followed by Parichiti can be broadly divided into two categories, one related to its capacity as a grassroots NGO and the second associated with being a member of a network of about 62 non-governmental organizations (called Maitree $^{2}$ ) working in Kolkata. Some of Parichiti's programs are as follows

- Carry out a survey to learn about the working and living conditions of the domestic workers.

- Provide assistance in organizing the domestic workers

- Retaliating (through legal means) and protesting against any incidents of crime or torture perpetrated on domestic workers

- Taking part in various activities connected to the women's movement in India

\footnotetext{
1 The Global Fund for Women is a grant making foundation based in San Francisco supporting women's human rights organizations around the world (operating in 162 nations) working to address critical issues such as gaining economic independence, increasing girls' access to education and stopping violence against women. Since its inception in 1987 , the Global Fund has given $\$ 44$ million to support 2,900 women's groups (Global Fund for Women 2005).

2 Maitree is an umbrella organization dealing with domestic health, consciousness raising, social upliftment, and violence against women in the workforce ( Parichiti, Personal Communications).
} 
Parichiti conducts meetings (the first meeting was held on Dec. 12, 2004) at the railway stations at strategic spots where the maids gather to board their trains. The meetings are held for approximately two hours each day (from 12.00-2.00p.m., once or twice a week) and are attended by about sixty maids on average, in batches of ten to fifteen. Apart from an animated exchange of ideas, information and future strategy planning, these meetings are also part of a 'politics of visibility'. The maids here get a chance to show off their connections with members of the NGO, who sit on the ground along with them. There is also a united show of defiance as the maids gather under posters depicting the travails of their work, under the gaze of the employer class with whom they share space on the platform.

A survey has been conducted by Parichiti among 200 maids who hail from different villages of South 24 Parganas district. While a large number of the maids (170) covered by the survey work in neighbourhoods close to the Dhakuria station, others (30) work close to the Jadavpur station. This 'self survey', to borrow a term from Appadurai 2001b:34), is aimed at establishing a general background of working conditions in this sector and their common areas of concern. The survey has also helped to spread the idea of sharing experiences of organizing among the maids and the NGO as each tries to gauge the other as potential partners. It has also served to establish the maids as the primary members of the organization and to recognize them as workers, something that has been denied to them by the laws of the land.

The principal purpose of the meetings is to form a bond of trust and partnership between domestic workers and the NGO and to work towards creating a platform based on common interests, needs and problems. Various methods are used to achieve these 
aims, like conversations, drawing of posters, organizing games (like ludo), and questionanswer sessions. Combination of these methods and the regular intervals at which these meetings are held have already started to show their impacts. A collective entity is slowly emerging among the maids and links are being made between them and the staff at Parichiti. Reports of their work and family life are exchanged at these meetings and opinions and advice are sought on various issues. Based on these revelations and insights, members of the organization have drawn posters and written messages which are put up for display for general viewing during the meetings. These activities are popular among the maids and participation produces a cathartic effect whereby the conversations flow easily in the excitement generated, and many bitter memories can be shared without unduly depressing the maids. The maids, who have very little time to devote to themselves, look forward to these occasions to breakup the drudgery of everyday life. The staff also has plans to organize picnics and more social get-togethers (for example to celebrate occasions like the Independence Day and Women's Day) in the near future. However the organization is very careful not to impose any of its agendas upon the maids. The staff has been cautious not to try to be the voice of the maids and restricts itself to a supportive role. They want the maids to fix the agenda of the movement by themselves in a bottom-up fashion, with the NGO providing the infrastructure required to nurture the effort. As the NGO members do not experience the working lives of the maids, they feel that the momentum of the movement should be carried by the maids themselves. Thus they have taken a wait-and-watch approach as the collective entity of the maids is slowly gearing itself to further its organizational plans with the assistance of the NGO. 
Another important aspect of the work carried out by Parichiti involves domestic workers of another category, namely those who work as full time live-in maids. Parichiti's main focus in such cases has been females who are legally minor and who are sent to work at the employer's place by their parents/guardians. This is due to the fact that female children are often considered to be burdens in this social milieu (Roy 2003). Some of them face extreme physical, mental and sexual torture at the employer's place which can ultimately lead to suicide or murders. Parichiti uses media sources to track such cases and provides organizational and legal support to the child/family to fight legal battles or rehabilitate the child. It also aims to run campaigns to sensitize the public regarding the violence faced by such child labour and put an end to it. Some other programs run by Parichiti include joining campaigns demanding better provisions for women in work places or public transit and in the legal set-up of the country.

The most important problem singled out by the NGO staff, that has prevented a more effective participation of the maids in efforts to set up a representative organization, is their lack of time. Burdened with enormous responsibilities at home and work, they have very little time on their hands to devote to such activities. So far, the NGO has only been able to organize meetings with them for short durations on the railway platforms where they gather together to wait for their respective trains. The NGO too is hampered in this regard as its present office is located some distance away from the railway station preventing it from becoming an alternate meeting ground. Thus, the unavailability of both space and time has become a problem. The NGO is therefore trying to relocate its office to premises more accessible to the maids as well as successfully encouraging the maids to 
appreciate their collective strength and devote more time to organizing efforts as a long term investment on their interests.

The second difficulty pointed out by NGO staff is the hostile attitude of the middle class against any action on the behalf of the maids that would harm their own self interest. Despite efforts on the part of the NGO, the middle class has failed to extend its support on even fundamental issues such as human rights. For example, when the NGO was fighting a legal battle and wanted to commission witness support from among the neighbours of a middle class family which had forcibly kept their live-in domestic helper under detention, it was unable to do so. The neighbours apparently decided to cooperate with one another or at least not connive against each other in apprehension of similar charges being leveled against them.

The third problem which has hampered the growth of a collective movement is the presence of various types of work contracts which are decided upon on a one-on-one basis between domestic worker and the employer. The nature of the exchange and the relationship that follows from these contracts also shows a wide variation. While some of the domestic workers remain satisfied with their arrangements others are not, creating different degrees of desire to organize among them. The lack of any history or experience of organizing among the workers of this sector is also causing a slowdown in the pace of progress. The competition among the maids to replace each other in a labour surplus economy has contributed to strengthening the unequal power relations that the employers enjoy in the bargaining process. 


\subsubsection{Nishtha}

After the passage of three decades since its birth in 1974, Nishtha has come a long way since its humble beginning as a mahila mandal (local women's association) that ran a school and a free medical clinic in the Baikunthapur village located in the south 24 Parganas district in the suburbs of Kolkata. As younger leaders came to the helm, a more radical approach was adopted, with emphasis laid on stimulating the female consciousness towards a tenuous trek to gain control of its own destiny. Today Nishtha has been able to spread its organizational network over 60 villages, touching the lives of 95,000 people inhabiting these villages and encouraging change in the way they live.

The organizational framework consists of a general body of 11 members who elect seven from among themselves to form an executive committee. Three members of the executive committee work full time for the organization and are in charge of day-to-day affairs. There are also 35 field workers who help the office bearers in their task. However the organization's main backbone is its large group of volunteers, divided according to age categories. The most junior group is called the Balak Balika Bahini (children's group) consisting of children from 6-9 years of age. The total strength of this group was 1121 members in 2005 . Training is provided to this group geared towards awareness building along with sessions to deliver formal and non formal education. The second group is called Kishori Kishore Bahini (adolescent group), consisting of members from 10-18 years of age. There are at present 74 such groups affiliated to the organization with 4210 members registered under them. Some of the important programs followed by this group include training in communication skills, legal rights, sexual and reproductive health knowledge, knowledge in local governance, knowledge of the environment and the 
like. The third group is called mahila mandals (women's group) consisting of women in the age group of 19-54years. There are 162 such groups now spread over 60 villages with a total membership of 4228 at present. The main concern for these groups is to build a campaign against all sorts of exploitation and violence committed against women in general and also to extend a helping hand towards poor, distressed and ailing women. Nishtha has encouraged these processes with support and advice and free legal aid as and when required. The fourth group consists of senior women of the age group of 55 and above. There are 6 such groups which include 190 members. Nishtha has utilized their repository of knowledge and experience as a guide to carry forward the organization's goals.

The programs followed by Nishtha have been directed towards achieving its prime goal which has been the empowerment of women and preventing discrimination against them. Their various programs are aimed towards assisting women to realize their rights, their dignity and to help them gain access to the opportunities that they have been denied. It has tried to achieve this through various programs, some of which are as follows

- education and support for first generation learners

- clinics and workshops to look after women's health and hygiene needs

- awareness regarding sexual and reproductive health

- generating funds to help women to establish micro-enterprises and self employment schemes

- rural development schemes where women are prominent participants

- alternate vocational skills for sex workers

- leadership and advocacy training through organizing meetings, one act drama/role plays

- agricultural training for women farmers.

Although Nishtha initially started as a women's organization, gradually a need was felt to induct members of both the sexes to the organization's activities, even though the emphasis remained on women. Participation of both the sexes was felt to be necessary as 
exclusion of one half of the society will create further competition and growth of divisions, perception of threats and mistrust among the members. On the other hand inclusion of all willing members will create room for development of mutual trust and cooperation, sensitivity and awareness which can only serve the good of the society. A particular incident prompted the leadership in Nishtha to reconsider this issue and bring about a change in its perceptions. When Nishtha launched a campaign to increase the pay of women agricultural labourers of the area and to bring it on par with their male counterparts, it was the male labourers who put up the most formidable resistance thereby acting in landowners' interest despite the fact that the women were from their own families and their increased income would augment the family budget. The deeply ingrained prejudices against women's inferior position in society and the need to maintain a higher status at work as well as in family life guided the male reaction. This failure of one of Nishtha's campaigns galvanized it to widen its base and initiate gender awareness programs by including members of both sexes in its organizational efforts.

Nishtha has also carefully charted a political image for itself by remaining politically neutral and not supporting any party politics but at the same time encouraging the growth of links with the administrative machinery. Its political neutrality is evident in the fact that its panchayat members are independent candidates without support from any party. This strategy has prevented Nishtha from having to submit its agenda to dictates of any political party. However at the same time, it has actively encouraged (in a manner similar to what Appadurai describes as 'politics of accommodation' (Appadurai 2001b:29)) a closeness to the administration (largely politicized in West Bengal where one party has been at power for a long time and firmly maintains its control over the 
bureaucracy) in order to use it for its own ends (such as to keep local criminals at bay or to compete for government schemes or loans). For this, the local police station's help is commissioned at regular intervals to educate the youth about legal rights and duties, the help of the district administration is sought in financial and legal matters, and ministers and governors are invited as chief guests during the inauguration of new schemes.

Nishtha's general programs are mainly aimed at facilitating women to form organizational networks among themselves. This has been a difficult challenge, given that the women are trained from an early age to follow a secluded life. Gradually as she grows up her senses are refined towards an anti-organizational mindset, leaving her vulnerable to attacks on her individual self and detaching her from any form of support and information that her membership in a network outside household would have provided. Nishtha has challenged this practice by encouraging women to organize at all levels. Although women are the main focus of these programs, the seeds of organization are implanted at much earlier ages to make them strongly ingrained within the personality.

An effort has also been made on the part of Nishtha to break the gender bias of the society by inducting individuals of either sex to form mixed groups which work for rural development programs. These groups are mainly engaged in such specific tasks as village road constructions, cleaning of ponds and wells, repairing embankments and planting trees to increase tree cover. Female participation in tasks which are generally considered as male responsibilities have helped to loosen norms about gender segregation. The members receive valuable practical training through involvement in every stage, from planning to fund raising and material gathering, and finally execution of the tasks. The 
engagement of the mixed groups generates a feeling of equality among the participants and pride in their joint contributions. The villagers are also becoming acclimatized to these 'novel' sights and are in many instances providing encouragement and assistance in different ways.

Another scheme actively pursued by Nishtha has been to train female farmers in more advanced eco-friendly methods of farming. Experts are called in once a week to conduct classes in sustainable agricultural methods which aim to train farmers to use organic and cheap inorganic ingredients to prepare fertilizers and pest repellents and build up a community seed bank, from which the members can purchase or borrow during the sowing season. This scheme has helped to further the espoused goals of the organization in two ways. First, since the beneficiaries of this program have been women, they are acting as harbingers of these better technologies in the rural economy, thereby earning respect and power from fellow villagers among whom they are spreading this knowledge while augmenting their income from agricultural produce. Secondly this has also provided an avenue for farmers to put their education to use as they utilize it to gain knowledge about soil science and water management.

The mahila mandals also have fund rotation schemes and training sessions to help women set up small business enterprises, having to do with fish, poultry, piggery and tailoring. Women are given instructions on repairing relevant machines, maintaining accounts and marketing their produce as support services to function as viable entrepreneurs. Although Nishtha had plans to start crèches to help them with their preschool child care needs, shortage of funds have prevented such plans from taking shape. All these schemes are directed towards those rural women who would have had to head 
towards the city to gain employment as low paid insecure workers in the informal sector of either manufacturing or services, for example as domestic maids. In fact, some of the beneficiaries of these programs have been former maids who have given up their profession after accessing the benefits of the programs. Many more beneficiaries confessed that without these options, they would have to face a crisis of occupational choices and domestic work would have been one of the most likely options.

The main problem faced by the organization has been its inability to generate enough funds to expand the scale of operations and start new schemes. The funds for the organization are generated from a plethora of organizations, both national and international (SAHAY, Planned Parenthood Federation of American International, Ramakrishna Foundation, Vedanta Society of Studies USA, Pally Unnayan Samiti to name a few) as well as from individuals. On some occasions, the organization was advised by donor agencies to take up issues on their agenda (for example child trafficking) for which they had funds available rather than the ones pursued by the organization. This has created a conflict between what the organization strives to achieve and what it is being asked to achieve.

The second problem has been the resistance put up by the local population, especially at the initial stages, against allowing the organization to carry out its advocacy activities in the area. The staff has been accused of misdirecting the local women and 'polluting' their minds. Sometimes this resistance has taken up violent forms like locking up staff and forcibly keeping them under captivity until well past midnight. The tension could only be diffused under the intervention of some of the villagers who were more supportive of the organization. Many members of the mahila mandals also reported 
facing resistance at the beginning from family members (both male and female) which went to the extent of physical and mental torture and abuse. However with time, these have become things of the past as those same women expressed confidence in loudly announcing the goals of the organization as their own goals. They have also been successful in solving many of their local problems on their own volition rather than depending on the staff from the organization, thereby adding to their self confidence.

The third problem faced by Nishtha has been the inadequate administrative support for their different schemes. The experience of Nishtha had made it realize that one of the key reasons for a lack of gender sensitivity on the part of the administrative machinery is the low representation of women in governmental agencies. Although the $73^{\text {rd }}$ Amendment of the Constitution of India states that one third of the seats at the local level of government are to be reserved for women, many such seats lie vacant (Basu 1992:68). The response of the mahila mandals to this concern has been to start electing their members to the village panchayat (a local governing body at the village level). Although they have been successful in getting two of their members elected, they vowed to improve on this number next time. These two elected members have proven to be valuable conduits to direct government funds for development schemes aimed at grassroots women in the area. The elected panchayat members have also brought about a greater visibility to women's growing participation in local politics and have added a further dimension towards the goal of female empowerment. 


\subsection{Organizing for change}

In developing an agenda for action the first point that needs clarification is, what benefits, if any, can be obtained by asset-poor, insecure female workers from organizing themselves per se. This section explores the pertinent issues.

\subsubsection{Building on the alternatives}

It has been found that, through membership in organizations, workers can replace competition with cooperation among themselves or can pool their small financial resources for various productive activities (Carr et al. 1996:193-4). However conceivably the most meaningful impact to follow from such organizational activities is the perceptible increase in self esteem (ibid: 195). Organizational involvement helps in the growth of self worth or inner freedom for the women that can act as a powerful antidote against the disempowering effect of the socio-economic structure which contributes to the vulnerabilities of women. If such an exercise helps to recover the subdued and floundering voice of the subaltern, then it certainly makes sense to follow it.

However a note of caution must be sounded at this juncture about the precise nature of involvement that is advocated for external agencies which aims to take a meaningful role in aiding the process. The Participatory Action Research (PAR) approach as postulated by Fals Borda and Rahman provides a comprehensive course of action whereby popular and practical knowledge can be linked up to the acquisition of a political base and ultimately the sharing of power (Fals Borda and Rahman 1991). By adopting the roles of actors who decide the course and pace of action depending on their understanding of the situation, the population retains the leverage of change rather than 
continuing to depend on an outside agency to decide the direction of the movement. The task of the outside agency is to prepare for this change by constantly re-evaluating and adopting changing roles to fit the change of design as the movement takes off and gathers its own pace.

In the light of these two contentions, one which reiterates the importance of organization as a tool for empowering women and another which elucidates PAR as an effective means to use this tool, I now investigate some specific ways that these ideas can be put to practical use at the grassroots level. It is in this regard that I look into the activities of the two grassroots organizations Parichiti and Nishtha introduced before. As Parichiti deals with the domestic work sector and is a comparatively young organization that has yet to spread its roots firmly, some of these propositions may be more relevant to it than to Nishtha which has a more established base and is engaged in organizing a wider cross-section of rural women.

\subsubsection{Strategies and issues}

Organizing and supporting grassroots movements for the dispossessed and abused is a daunting task given the continuous exploitative relationships and the near total illiteracy that they are subject to. Organizations and individuals have however taken up these challenging tasks to address issues for specific groups. To facilitate a holistic solution, these organizations often chart out a set of activities that are intertwined in nature. I have therefore attempted to categorize the potential strategies that can be adopted, into five groups, to provide an easier framework for analysis. 


\section{Pressure strategies}

One important obstacle has been the lack of a uniform work contract. The contract inevitably remains an unwritten agreement subject to differing interpretations and treatment by employers and workers. In many instances, this has been the cause of conflict between the worker and the employer (as each tries to usurp the other's rights with the worker mostly emerging as the loser) and also a source of disunity among the workers (because of the differential relation with the employers that each develops). Under such circumstances, there is a need to draw up a common charter of demands for domestic workers which would include such issues as charges for each service, charges for extra duties, maternity benefits, health benefits and retirement benefits that will accrue to the worker after a certain period (decided by the worker). Realistically speaking, such a strategy will generate intense resentment among employers who will put up all possible resistance to it. However the success of the campaign will depend on the cooperation and unity achieved among the maids and their resilience in the face of intense pressure.

Secondly domestic workers need to travel long distances to their places of work. These journeys are conducted in overcrowded trains creating great strain among the workers. Also a combination of high ticket prices and low salaries prompts many of them to travel without tickets. This creates tension between the domestic maids and the railway authorities. In view of the continued need of the maids to use this mode of transport on a daily basis to reach their place of work, there is a need for the authorities to subsidize tickets according to the income earned by these commuters. As well, the railway authorities should also be pressurized to increase the number of trains linking the suburbs 
to the city especially during peak hours as the trains carry passengers in excess of their capacities, creating conditions of great discomfort among the passengers.

\section{Advocacy approach and empowerment strategies}

As one of the important impediments faced by the maids is the shortage of time that they have at their disposal to attend meetings, the NGO can arrange two to three short meetings of twenty to thirty minutes duration at fixed intervals during the week (any of which the maids can attend) and a larger general meeting twice a year. During the weekly meetings group discussions can be initiated to strategize on future courses of action. The individual resistance strategies used by the maids can become a useful starting point to guide future resistance strategies that the organization can adopt at a collective level. These occasions can also be utilized to discuss similar organizing activities in other parts of the country and the world. Such information sessions can help workers realize the global nature of their movement and also learn from their experiences. The external agency can become a useful agent for providing such academic knowledge because of the comparative advantage that they enjoy in accessing such information.

Another way of raising 'critical awareness', to borrow a term from Fals Borda and Rahman (1991), is through the screening of videos and documentaries (a media popular among the maids as even the illiterate and the semi-literate in their midst can understand them). Such screenings can be attended by the maids along with their families. These occasions can then be used to introduce new ideas or generate consciousness about novel concepts, for example alternate gender roles. These screenings can be followed by debates and discussions about their relevance to the present context and future plans. 
Through such an exercise a public discussion of hitherto private issues can bring to the forefront the relative merits and demerits from the perspective of each viewer. Nishtha has used the medium of open theaters and street theatres whereby training is provided to village teenagers who act out plays on sensitive gender issues like child marriage, dowry deaths and the like during different occasions in the village to sensitize villagers on malaises that afflicts society.

Again, although it may seem to be a daunting task at first, given the lack of time and the age of the maids, efforts should be made to teach them basic literacy skills so that they are to read, write and be comfortable with the numerals. (It was interesting to observe that despite their illiteracy, the maids recognize money, can read time from clocks and can perform simple arithmetical tasks). A sense of loss could be detected among the maids when they discussed their inability to attend schools when young. However differences of opinion persist among the maids on the role that education played in their lives. While some considered education to be an elite luxury that the poor could not attain and even if attained could not use it to get out of their misery, others had a different opinion. They considered education to have an intrinsic value the effect of which could be felt in every aspect of life rather than only as a means to attain a better economic status. This group was eager to attend such a facility if available. Therefore this group could be targeted with this program and they could also form a useful vehicle to spread the idea of female literacy within the community of the maids which had remained somewhat limited so far. These occasions can also be used for confidence building and to provide leadership training to the maids. A maid who was a member of the mahila mandal in Nishtha described her transition after joining the group thus; "Previously we 
used to be afraid to go to a new place on our own and do any dealings with outsiders. We used to go in groups. We were afraid to talk to strangers. Now we can all go alone and do our dealings with the banks and post offices, from filling the slips, depositing them, withdrawing and depositing money. Previously we were afraid of the outside world but now I travel on my own to Kolkata." These are the examples which need to be replicated and developed upon.

\section{Financial service}

The opinion of the maids needs to be sought in regard to any financial intervention that they may deem necessary in order to attain financial security. Many of them reported how they had to depend on private money lenders to secure loans at high rates of interest in times of financial crisis. Sometimes they took alternate avenues like saving money with agents of private financial institutions. These agents were frequently family members or persons of acquaintance who used their contacts to convince their clients about the soundness of their institutions. However in many cases, women find themselves duped, leaving them bereft of their hard earned money and faith in the system. They also sometimes kept money in storage containers made of clay, in their homes, but were afraid of their safety because they could not guard it always and had to depend on the goodwill of their family members. The official banks and post offices with fixed business hours and lengthy procedures and no programs of micro credit or micro financing facilities provided little incentive for the lower income groups like the maids. As experiments by other NGOs like SEWA or CDF in India and BRAC or Proshikha in Bangladesh (Carr et al. 1996) have shown, such financial interventions go a long way in augmenting the financial security of women and helping them to expand their sources of income and 
distribute the risks. The mahila mandal at Nishtha had also at a local level been successful in mobilizing small savings and installing a circulatory loan provision scheme for members of the mandal. A former maid and now a small time trader who benefited from such a scheme at Nishtha described her experience in the following words, "I used my salary from work to contribute to my savings after joining this scheme of the mahila mandal. After one year, I took a loan and started a small production of puffed rice which I used to sell in the neighbourhoods in which I worked. Gradually it became my full time activity. I used the profits to pay off the loan, look after the needs of my family and a portion as savings for the future." Such micro credit and saving organizations at the grassroots level therefore have been able to mobilize and utilize savings to a greater extent where other official agencies have failed. They have also provided women with a multiplicity of financial options and encouraged the growth of thrift and savings for the future.

\section{Entrepreneur development}

My research on the domestic work sector has demonstrated how the oversupply of labour has glutted the market which has largely contributed to depressing the salaries of workers. Many of these workers are displaced agricultural labourers lacking in training and assets which can facilitate their entry into alternate sources of income. As entry into domestic service does not require any financial liability, they readily crowd into this sector. However this labour market has its limits and there are signals that the supplies are closer to the limit than apprehended. Low salaries, the inadequate number of jobs available, the acute competition for the ones available are some of the issues that have already come to plague the sector. Under such circumstances there is urgent need to 
provide options for supplementary or alternate incomes for the maids. While financial credit and loans can help the maids to initiate these enterprises, assistance should be provided in the form of skill training, information regarding the market, links to the market and access to newer technologies. Again Nishtha has set an example in providing training to rural women in fish culture, poultry keeping, setting up small businesses in food grain, fruits, imitation jewelry, chikon sarees and the like. They have established a two tier loan structure. While the larger loans are given to group members after having attained some experience and success in doing business, the smaller loans have no such stipulations and are given even to non-members. The aim here is to begin the process of experience gaining both at the market level and also as a member of a group. They have also helped the small promising entrepreneurs to get access to markets by helping them to establish links with relevant cooperatives. Adoption of such approaches has helped in creating newer avenues of empowerment for rural women and has provided them with alternatives other than domestic services. Many of the maids, specially the newer entrants, who find it difficult to find jobs can be provided training for alternative employment which in turn, in the long run can decrease the pressure of excess labour in this sector.

\section{Advanced stage strategies}

The two NGOs that were studied during the research process were observed to have two distinct areas of operation. While Parichiti works in the urban areas which form the site of work for the maids, Nishtha works in the rural areas from which large numbers of maids originate. There is a need for the two organizations to work in conjunction with one another and better cover the different aspects of the maids' lives than they can do by 
working singly because finances and personnel are scarce resources for both the organizations given the enormity of the tasks that they have embarked upon. Though Parichiti is a much younger organization than Nishtha, Nishtha can learn from Parichiti's expertise in organizing the domestic workers and Nishtha needs to share its experience by providing training facilities to workers of other NGOs, like Parichiti. In fact, given that women's organizations have grown mature in the villages that Nishtha has been working for all these years, it is perhaps time for the organization to steer them towards complete autonomy and concentrate in newer areas where there is a crying need for interventions such as providing immediate shelter, medical aid and support to abused women who are forsaken by governmental agencies. A potential case is discussed in the next section.

\section{4 'Pulama'-A case study}

During my period of involvement in field work with Parichiti, I was part of a team that had dealt with the case of Pulama, a domestic maid who had suffered severe physical and mental abuse in the hands of her employer which I describe below.

\subsubsection{A studied case of continued abuse}

When we first went to meet Pulama, she was going out to call her two sons playing in the neighbourhood playground to give them two bowls of muree (puffed rice) which was the only snack that they get before taking their one meal a day. Pulama lives in a small suburban town to the north of Kolkata which took us about three and a half hours to reach by train. The neighbourhood in which she lives has residents belonging to different income categories. Residents who are from the higher end of the income scale live in 
large sprawling houses while those at the other end mainly rented huts constructed out of thatch and mud and huddled against each other. Pulama and her family of five members had moved into this neighbourhood some three years back. She is the sole supporter of her family and works as a maid in four houses in the neighbourhood. Her husband used to work at a tea stall on the railway platform but had subsequently lost his job when railway police had demolished the stall on the notion that it was an unauthorized structure though he alleged that his inability to pay bribes had been the main reason. Following this loss of livelihood he had grown physically and mentally depressed. He could find only odd jobs in the neighbourhood which did not fetch an adequate income and Pulama who was already working as a part time maid, now had to take up the entire responsibility of supporting her family. They had three sons between six to ten years of age. Under the pressure of poverty, Pulama had to discontinue the education of her elder son and send him to work as an apprentice in a jewelry-box making unit where the owner only gave the boy food and boarding but no salary for his work. The two younger sons lived with the couple in their tiny hut and attended the free primary neighbourhood school.

One of Pulama's employers was one of the richest families in the neighbourhood. There were nine adult members in that family who were all engaged in permanent well established jobs, either in the State or in Central Government services. After working at this employer's place for one and a half years, one day when it was detected that a sum of four thousand rupees and two items of gold ornament were missing from the family's locker, Pulama was charged of the theft. Despite protests of innocence she was dragged to the police station by the head of the family and a complaint of theft was lodged against her. At this point, the local police station conducted a preliminary inquiry and finding no 
evidence against her, dismissed the charges against Pulama. However, not satisfied with the turn of events, her employer brought Pulama back to his house and behind closed doors began to physically assault her. When Pulama still went on alleging her innocence, she was dragged to a neighborhood sporting club where some of the family's friends joined in to continue the assault, this time with sticks. Pulama pleaded that she was pregnant but they showed no mercy and after a while she lost consciousness. Her husband who came to know of the incident tried to come to her aid and was beaten up in turn. Some of her neighbours, who also worked as maids, raised an alarm and with the aid of the local mahila samity (a organizational unit of local women patronized by the dominant political party in the ruling coalition in the state, the CPI(M)) informed the police. The police then came and got her admitted in the local hospital. She remained in the hospital for eight days. When she had recovered sufficiently Pulama lodged a complaint of assault with the police against nine of her employer's family members. However none could be arrested as each of the accused had obtained anticipatory bail in advance. Pulama had injuries on different parts of her body and a broken right arm. The fate of her unborn child was yet to be determined. When she was released from the hospital she was barely able to stand and walk a few steps. Her whole family faced starvation.

When this was the state of affairs, the mahila samity began to play an important part. They had intervened by calling in the police and had also been active in generating funds from among community members to support Pulama's family. They now stepped in to pressurize the employer's family to pay compensation to Pulama for the violations that she had suffered and also for incapacitating her. When the employer's family failed 
to respond, they decided to flash the news in a leading vernacular daily (Anadabazar Patrika, Jun.19, 2005). Parichiti followed this news clip to trace the case and establish contact with Pulama.

When we went on Parichiti's behalf to investigate the case, we first met Pulama and her family. After the formal introductions were over Pulama started to recite the case to us. In the meantime she directed her husband to inform the mahila samity members of our arrival. Within a small period of time, a small crowd had gathered in front of her house. Pulama, who seemed unsure of how best to deal with the situation, visibly relaxed at the arrival of the members of the mahila samity. The president and the secretary recounted the incident for us highlighting the role of the mahila samity in generating public sympathy and funds for Pulama and her family. When asked about their future strategy, the members admitted that their pressure tactics had worked and the employer's family had agreed to proceed to the bargaining table in order to avoid the case being dragged to the court. The members were also eager to avoid a court case and looked at it only as a last resort. They knew that they had to pay all the fees involved on Pulama's behalf, and given the indeterminate time period involved in deciding court cases and the uncertainty of the verdict, they thought it best to avoid legal hassles if possible and had also advised Pulama and her family likewise.

The maids' community of the area, some of whom were also present during the meeting, had a different take on this issue. They were more in favour of finding the actual culprits in order to assuage the injured dignity of their community rather than following the path of appeasement that the club members were following. However their inability to support Pulama and her family unlike the mahila samity, had impeded them from 
asserting their viewpoint and Pulama had also become financially dependent on the mahila samity members and seemed to agree with them more.

Clearly we as Parichiti members were late arrivals in the scene. Our direct intervention was not very welcome by the mahila samity members who had become powerful players in the incident. The president of the mahila samity openly admitted her scheme of using this issue to extend her party's image in the area as a champion of the poor. The role that they sought from Parichiti was that of moral support rather than any active involvement. We therefore had to remain satisfied with the status-quo as Pulama naturally sought the local mahila samity as her ally rather than a little-known organization which was located far away. Parichiti exchanged contact addresses and numbers with mahila samity members as Pulama had no access to a telephone. Parichiti also promised legal aid if a court case was pursued after all. Then with repeated requests to the mahila samity members to receive a regular update on the case, we left the scene for the first time.

After a week or two of waiting when Parichiti could not get any response from the mahila samity members over the telephone, it was decided that a follow-up inquiry was required. This time when we went to visit Pulama, a subtle change in the atmosphere could be detected. The crowds outside were missing, indicating a waning of public interest in the case. The mahila samity members were also not readily available for comment and after a long wait we could meet only one member. By then Pulama had already informed us that the meeting had already taken place and a consensus had been reached on behalf of both the parties and an agreement to that effect had been signed. While the mahila samity had asked for Rs. 20,000 along with medical charges for 
Pulama, the employers had declined and instead a lower sum of Rs. 16,000 had been promised out of which Rs. 6000 had already been paid. The members of Parichiti expressed surprise at this small amount, as a verdict against the employers in a court case would have resulted in the detention of the accused party in a police lock-up at least for a day. Under the law of the country, a person who spends twenty-four hours in a jail can be dismissed from government service on this ground. In view of the gravity of the case, the agreed amount seemed paltry. Moreover, the irreparable damage to the unborn child was also a matter to consider. At this point Pulama agreed with the Parichiti members and tried to voice her dissatisfaction at the small sum of compensation that she had received. However the secretary of the mahila samity put an end to all the musings by reminding her that it was Pulama herself who had signed the agreement when the sum was decided in her presence and threatened to report against her in the mahila samity. Pulama responded to the threat by quickly withdrawing her complaint and expressing her satisfaction in the agreed amount. We at Parichiti failed to defend Pulama for a second time and left the scene, bitter at the betrayal of the interests of a poor woman, by women who claimed to represent the poor and yet continued to protect the constituency (middle class voters - Pulama's employers) of their party along with the state.

\subsubsection{The realizations for Parichiti}

A thorough perusal of the incident in hindsight and our inability to deal effectively with the situation at hand, led to a crisis of confidence and soul searching at Parichiti. Although gained at a high cost, it gave us valuable insight into our inadequate understanding of the situation and the weakness in our organizational strategies. 
First a critical look at the mahila samity president's handling of the situation has to be undertaken. The mahila samity with a middle class membership tended to look upon Pulama and the other maids as an object of their welfare activities rather than fellow women fighting against superior forces in society that infringe on their dignity and freedom. The overriding mood pervasive among the members of the mahila samity was to consider Pulama as a victim fit for pity. Pulama and her husband were considered boka (stupid). They were being continuously chided for 'inappropriate' behaviour in a manner that is generally reserved for children. Their continuous poverty, even after the theft had been committed at the employer's residence, was considered to be evidence enough of their innocence. At the same time Pulama was also accused of chalaki (cunning intelligence) when she voiced her concern regarding the small amount of the compensation money and a firm warning was issued against continuing in a line of action that would result in confrontation with the mahila samity.

Again Pulama and her husband were continuously berated for their inability to practice family planning in front of a crowd of outsiders. Pulama's feeble protests that her health deteriorated when she used contraceptive pills were given no value and was treated only as an excuse that the couple used to avoid adopting birth control measures. It was as if with poverty, the couple had lost their intelligence and their independence. Conformity with middle class values was their only road to salvation. Aborting the fourth child was espoused as a sensible resolution to limit Pulama's poverty rather than as a consequence of the physical assault that Pulama had suffered at the hands of the employers. 
The two most important reasons for Parichiti's inadequate response to the situation were, first, a lack of funds to take up financial responsibility of the destitute family. Second, the presence of a large organized ruling party of which the mahila samity was a segment and its willingness to take up the issue to increase its support base in the area, acted as a deterrent against Parichiti. Parichiti with its small base in a far away area could not match the local mahila samity's might which had been involved in the case from a much earlier phase. In fact the distance and the lack of communication had been very important factors to explain why Parichiti could not keep a closer link with Pulama's case. A further liaison with Pulama about the possible options should have been pursued by Parichiti before the meeting with the employer took place. By denying Pulama any useful information that could have strengthened her position at the bargaining table, Parichiti had failed to provide the necessary aid to Pulama.

\subsection{Not a time to conclude yet...}

The objectives of this research have been to investigate the value that society attaches to women's contributions to their socially productive and reproductive roles. The dominant discourse appears to be heavily biased towards a male outlook whereby any work which does not involve economic exchange is considered to be less worthy of attention (Bauman 1998: 96-7). Men long ago moved their area of operation away from the home and explicitly carved out an activity schedule that is both visible and involves

monetary exchanges (Weber cited in Bauman 1998:96). Women's responsibility of supporting these structures has conveniently been labeled as secondary, unskilled or nonremunerative. In this thesis an effort has been made to progress from this starting point 
and look at the impact of such an underlying discourse in determining the value of what has been called 'women's work' as it makes its entry into the precincts of paid work in the Indian context. The unpaid work now becomes a paid occupation and the women engaged in it are called domestic workers. However these changes in labels do not necessarily indicate a change of values. As is evident from the research findings, the workers of this sector still carry their original classification of being unskilled and superfluous. Their rights and privileges make their presence felt through their absence. However, as cogs and nails that join the superstructure together, it is their contribution which causes the employer households to function while they themselves are denied the pay and benefits that should justly match their efforts. As silenced workers whose resistant voices fail to make themselves heard in official circles, their destiny is to remain as dregs of a society maintained by their sweat and tears. They remain very relevant to the economic welfare of the society and yet are 'invisible' to it.

And what exactly is that society? The research exposes them at all levels as the state, the community and the family. As programs like the SAP shape the reality of the third world, and welfare states become things of the past, the global community effectively passes its burden on to the overstressed shoulders of poor women whose share in the global distribution of resources is miniscule to begin with. Governments at the national and state levels in these countries have to struggle with the spiraling unemployment and poverty exacerbated by the policies mentioned earlier. To counter these traits, which in turn question their legitimacy the governments can only respond by formulating strategies that enhance the expansion of the informal sector. This is due to the fact that their hands are otherwise tied by the economic guidelines imposed on them 
by these policies. This in effect ensures that the workers in the informal sector, a majority of whom are women, continue to lose their rights to adequate compensation and better working conditions. The women find themselves at the bottom of multiple repressive regimes. The patriarchal values of a society rob these women of education, of avenues to access training, of an asset base to start an independent profession and of an organizational network to derive strength from their collective agency. It is also true that the adverse conditions that these marginalized women face are perpetuated by another group of women who by virtue of their economic superiority want to maintain the statusquo so that they can enrich their lives at the expense of their weaker kin.

However this research has not been about women who are victims or losers, for such clear cut divisions do not exist as the everyday experience of these women have shown. The struggles and the resistance that these women put up into their family life, their work life, their dealings with the state, the lives of their daughters- are all proof that the subaltern does speak. There is a need to pay heed to these voices that rise from the grassroots. Though at present they are largely isolated, muted and limited in their span, they are gradually making their presence felt. The mobilized unity and empowerment at the grassroots that are dreamt of at organizational levels like Parichiti and Nishtha can be effective devices to pressurize the civil society and government to start moving towards recognizing the rights of neglected workers such as the domestic maids. A reorientation of objectives at all interfaces of exchange - political, social and economic is required. The need of the hour is to build public awareness towards an alternative evolution which can impart better social and economic justice to the marginalized sections of the society. This research has been a small effort towards that goal. 
Appendix - A

Snapshot of the profiles of the maids

\begin{tabular}{|c|c|c|c|c|c|c|c|c|}
\hline $\begin{array}{c}\text { Serial } \\
\text { No. }\end{array}$ & $\begin{array}{l}\text { Age } \\
(y r s)\end{array}$ & Education & $\begin{array}{l}\text { Marital } \\
\text { Status }\end{array}$ & $\underset{l}{\operatorname{Emp}}$ & $\begin{array}{l}\text { Years of } \\
\text { service }\end{array}$ & $\begin{array}{l}\text { Monthly } \\
\text { Income } \\
\text { (Indian } \\
\text { Rupees) }\end{array}$ & Other Benefits & $\begin{array}{l}\text { Introduced to the } \\
\text { profession by }\end{array}$ \\
\hline 1 & 45 & illiterate & $\begin{array}{l}\text { Married } \\
\text { but } \\
\text { deserted }\end{array}$ & 6 & 15 & 900 & $\begin{array}{l}\text { Snacks, Saree/cash bonus } \\
\text { during festivals }^{2}\end{array}$ & $\begin{array}{l}\text { Fellow village } \\
\text { women working as } \\
\text { maids }\end{array}$ \\
\hline 2 & 30 & illiterate & Married & 5 & 5 & 1000 & $\begin{array}{l}\text { Snacks, cash loans during } \\
\text { emergencies }\end{array}$ & Sister-in-law \\
\hline 3 & 35 & Illiterate & Married & 3 & 20 & 900 & $\begin{array}{l}\text { Sarees during festivals, cash } \\
\text { loans deducted from salary }\end{array}$ & - \\
\hline 4 & 45 & Illiterate & Married & 4 & 7 & 1000 & Snacks and lunch & $\begin{array}{l}\text { Fellow village } \\
\text { women working as } \\
\text { maids }\end{array}$ \\
\hline 5 & 45 & Illiterate & Married & 4 & 5 & 800 & Snacks & Sister-in-law \\
\hline 6 & 35 & Illiterate & Married & 3 & 3 & 430 & $\begin{array}{l}\text { Snacks, cash bonus during } \\
\text { festivals }\end{array}$ & - \\
\hline 7 & - & Illiterate & Married & 4 & 8 & 550 & $\begin{array}{l}\text { Snacks, saree/cash bonus } \\
\text { during festival s }\end{array}$ & Sister-in-law \\
\hline 8 & 70 & Illiterate & widow & 9 & 40 & 900 & $\begin{array}{l}\text { Sarees during festivals, cash } \\
\text { loans deducted from salary }\end{array}$ & $\begin{array}{l}\text { Fellow village } \\
\text { woman working as } \\
\text { maid }\end{array}$ \\
\hline 9 & 50 & Mliterate & Married & 6 & 17 & 1000 & $\begin{array}{l}\text { Snacks, lunch, assistance } \\
\text { during daughter's marriage }\end{array}$ & Sister-in-law \\
\hline 10 & 35 & Illiterate & $\begin{array}{l}\text { Married } \\
\text { but } \\
\text { deserted }\end{array}$ & 2 & $\begin{array}{c}\text { Since } \\
\text { childhood }\end{array}$ & 800 & $\begin{array}{lcc}\text { Snacks } & \text { sarees } & \text { during } \\
\text { festivals, medicines } & \text { during } \\
\text { illness } & & \\
\end{array}$ & - \\
\hline 11 & 32 & Illiterate & Married & 5 & 2 & 900 & $\begin{array}{l}\text { Assistance during daughter's } \\
\text { marriage, lunch and snacks, } \\
\text { Sarees/cash bonus during } \\
\text { festivals }\end{array}$ & Mother \\
\hline 12 & 45 & Illiterate & Married & 5 & 30 & 900 & Sarees during festivals & $\begin{array}{l}\text { Fellow village } \\
\text { woman working as } \\
\text { maid }\end{array}$ \\
\hline 13 & 40 & Iliterate & Married & 10 & 12 & 1800 & $\begin{array}{l}\text { snacks, lunch, saree/cash } \\
\text { bonus during festivals }\end{array}$ & Sister-in-law \\
\hline 14 & 25 & $\begin{array}{l}\text { Primary } \\
\text { education }\end{array}$ & Married & 7 & 3 & 1800 & $\begin{array}{l}\text { Snacks,lunch, saree/cash } \\
\text { bonus during festivals, cash } \\
\text { loans deducted from salary }\end{array}$ & Sister-in-law \\
\hline 15 & 23 & $\begin{array}{l}\text { Primary } \\
\text { education }\end{array}$ & Married & 8 & 1 & 1500 & $\begin{array}{l}\text { Sarees/cash bonus during } \\
\text { festivals, medicine } \\
\text { illness }\end{array}$ & Sister \\
\hline 16 & 50 & Illiterate & Widow & 4 & 22 & 600 & $\begin{array}{l}\text { Saree/cash bonus during } \\
\text { festivals }\end{array}$ & - \\
\hline 17 & 70 & Illiterate & Widow & 3 & 40 & 400 & $\begin{array}{lcc}\text { Snacks } & \text { sarees } & \text { during } \\
\text { festivals, } & \text { medicines } & \text { during } \\
\text { illness } & & \\
\end{array}$ & - \\
\hline 18 & 40 & Iliterate & Widow & 5 & 30 & 700 & 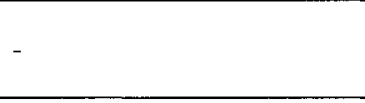 & $\begin{array}{l}\text { Fellow village } \\
\text { woman working as } \\
\text { maid }\end{array}$ \\
\hline 19 & 30 & Illiterate & Married & 6 & $\begin{array}{l}\text { Since } \\
\text { childhood }\end{array}$ & 1200 & $\begin{array}{l}\text { Old clothes, Cash bonus } \\
\text { during festivals, cash loans } \\
\text { deducted from salary, } \\
\text { medicine during illness }\end{array}$ & Sister \\
\hline 20 & 50 & $\begin{array}{l}\text { Primary } \\
\text { Education }\end{array}$ & Married & 3 & 14 & 500 & $\begin{array}{l}\text { Saree/Cash bonus during } \\
\text { festivals }\end{array}$ & - \\
\hline
\end{tabular}

\footnotetext{
${ }^{1} \mathrm{Emp}=$ No of Employers
}

${ }^{2}$ Gifts are given during the annual Durga Puja celebrations. This festival is the one of the most important religious events in the Bengali Hindu Calendar and is celebrated in the months of September/October 


\section{Appendix - B \\ QUESTIONNAIRE FOR DOMESTIC MAIDS.}

\section{SECTION - A: Personal Profile}

- Name, age, marital status, education, income, number of family members, number of children

\section{SECTION - B: Nature of the work of the Maids}

- Can you describe the work routine that you followed yesterday? Is this moreor- less the same routine that you follow everyday?

- What are the common duties that you have to perform in most of the households? Are there any extra duties that you have to do in any of the households? Why do you have to do these extra duties?

- Who describes the duties that you have to do when you join a new household? How is this done? Do they change in any way once you are in the job?

- What are the difficulties that you face in this job? How do you cope with them?

- What are the things that you like about this job? What are the things you do not like?

- On what basis do you decide the wage rate for your different activities? (number of duties you have to perform/hours of work/number of family members) Who else decides this with you? When did you have your last increase of pay in your workplaces?

- When was the last time that you took leave from work? On what other occasions do you take leave? Do the employers readily agree to these causes? Why or why not?

- How did your employers react when you made mistakes or when you take nonnotified leaves?

- What do you do if you think that you are being wronged? (stop working at the house/complain to other maids/go to the law enforcing agencies)

- How do you describe the work that you do? (male activity/female activity/can be performed by both) Why do you think so? 
- What are the work options that you have closer at home?

- What is the nature of job competition or job rivalry that you have in this work?

- Are you questioned about your caste when you enter a new job?

\section{SECTION C - Value of the maids - as individuals and workers}

- How do you and your family members benefit from your work? (Monetarily and non-monetarily)

- How do your family members help you? How do they create difficulties for you?

- Do you receive help from any external agency (employers /government / NGOs/individuals) for any assistance related to your work/health/monetary matters?

- Do you have friends among maids who have taken up other jobs like say in factories or as cooks or ayahs (nursemaids for children, sick or old)? What made them take up these jobs and how did they made it possible?

\section{SECTION D - Hopes and Aspirations}

- Given a choice, would you continue in this profession? If not then what would you like to do?

- What changes would you like to see regarding your work?

- What do you do in your leisure time?

- Would you want your child to enter this profession? 


\section{Appendix - C \\ REPORT OF MY DAYS SPENT AT PARICHITI \\ MANALI DUTTA}

\subsection{INTENT OF STUDY}

As part of the field work for my graduate research program, (in the department of Geography and Environmental Studies, Carleton University, Ottawa, Canada), focusing on the maids of South Kolkata who commute daily from the peri-urban areas, I had requested Parichiti (a NGO) to grant me permission to get involved in their activities as they addressed similar issues.

I am thankful to the members of Parichiti for allowing me to work besides them as a team member.

\subsection{NATURE OF ACTIVITIES}

Parichiti hosts a variety of activities. Amongst them, the ones that I was involved with focused on issues related to the commuting maids. Parichiti conducts weekly meetings called "clinics" at a local railway station (Dhakuria) in South Kolkata from 12:00 p.m. to 2:00 p.m. In these meetings maids are provided with a center to congregate and share experiences.

Parichiti collects information regarding the working and the living conditions of the maids and encourages them to share their difficulties and experiences. In this way Parichiti is trying to win the confidence of the maids so that they can bank on Parichiti when they are in conditions of stress or when they need assistance on various matters.

Parichiti also investigates abuses suffered by maids and tries to provide legal and moral help to the victims. 


\subsection{DETAILED OBSERVATIONS}

Parichiti members set up posters describing the various common experiences of the maids to build up solidarity amongst the maids. The issues that are highlighted in these posters include lack of holidays, lack of access to toilets, lack of refreshments, lack of sun-shades on rail-platforms where the maids congregate etc.

On an average, during the days of the clinics, around sixty maids attend the clinics, arriving in batches of approximately ten individuals. These maids wait in the station for about ten minutes before they board their respective trains to go home. The average time spent per group is around ten to fifteen minutes. Parichiti is represented by two to three counselors in these meetings.

During the discussions the maids indicate both the positive and negative behaviors of their employers and family members. They also discuss about the strategies that they employ to deal with adverse circumstances. These include both stealth and direct confrontation. They sometimes also use these meetings to vent their frustrations of the workload by openly cursing their employers.

Another issue that is discussed amongst the maids and supported by Parichiti is the importance of the value of educations. Though some of the maids are skeptical, majority agree that education plays a positive role in a child's future and some amount is required to get even the menial of jobs. They discuss the opportunities for education with the members of Parichiti. In some cases where the need is dire, Parichiti through other sister organizations helps in providing free education.

As they come to the cities for their work, they are also aware of the modern health facilities that are available. These make them less gullible to quacks practicing in their villages. Parichiti members also help them in these matters. 
During my association with Parichiti, I was involved in investigating a case of a maid abuse at Ashoke Nagar Road, whose travails had been flashed in a local vernacular daily. This maid, by the name of Pulama ${ }^{1}$ is the sole earner of a five-member family. She has three minor sons and an unemployed and mentally depressed husband. Two of her sons go to school while the eldest works at a jewellery box-making unit. The youngest son is mentally retarded. She was responsible for the expenditure incurred on account of rent, living expenses, education and medicines.

When a theft was discovered in one of the four houses in which she works which is in the same locality in which she rents her hut, she was beaten up by the employer and his friend with hockey sticks both at the residence of the employer and a local club to which she was dragged. Her husband was beaten up also when he went to her rescue and even the plea of being pregnant with the fourth child did not stop the blows. She suffered a broken arm and multiple injuries on the head and body. She was rescued by a police contingent when informed by the local Mahila Samity and some of her fellow maids.

Unable to go to work for some time now, she and her family faces starvation and eviction. Moved by her plight, the local Mahila Samity has intervened to demand some compensation from the employer. Parichiti members had offered to represent the maid in the negotiations for compensation. However as the local Mahila Samity had taken up this responsibility, Parichiti did a follow up over telephone a few days later after the scheduled meeting was held on the compensation amount.

The members of Parichiti learnt that the employers had agreed to pay the compensation but the amount was yet to be decided. After that when they went to visit Pulama who greeted them with a plastered arm, they heard that an amount of Rs 16000 was agreed upon as the compensation amount. The Mahila Samity had advised Pulama to use this amount to buy a plot of land as future investment for her family and to go around the neighbourhood with her ailing son to beg for help till she could work again. Pulama it seemed was not satisfied with the amount but had agreed to it as it was a consensus figure

\footnotetext{
${ }^{1}$ A pseudonym used in the thesis although the report submitted to Parichiti contains the individual's real name.
} 
and had kept silent. When Parichiti members commented on the inadequacy of the amount to provide for a family of five, during the time when Pulama will be forced to be inactive, she also joined in to voice her agreement. However as she had already signed the agreement, Parichiti members could not help her further on this issue.

\subsection{COMMENTS AND SUGGESTIONS}

- An office space close to the Dhakuria railway station can be contemplated to make Parichiti more accessible to the maids. This office should provide access to toilets for the maids. Also the services of a female doctor could be provided from this premise.

- More funds need to be acquired by Parichiti to enhance its working potential. Media exposure would help in attracting individual and corporate donors.

- As each case involves great commitment from each member, Parichiti will need more volunteers or workers so that the programmes are more effective as a single member cannot handle multiple cases efficiently. Again this would allow Parichiti to penetrate into rural base from where the maids originate.

- Parichiti could look into a crèche or day care center for the very young children of the maids.

- Parichiti could also facilitate the setting up of a cooperative for the maids wherein the maids can borrow funds for various activities and make small savings from their income for their old age. If this cannot be done at present then Parichiti can aid in raising prudent financial practices amongst the maids.

- Parichiti can act as a pressure group on behalf of the maids so that they can broker favorable working conditions for the maids and a separate travel allowance, which will enable them to buy railway tickets.

- Parichiti can help establish a uniform piece-rate for different categories of work usually performed by the maids like washing, cleaning etc over a given geographical area. 


\section{BIBLIOGRAPHY}

Abu Lughod, Lila, 1993, Writing women's world: Bedouin stories, University of California Press, Berkeley.

Afshar, Haleh. and Agarwal, Bina, 1989, 'Introduction', in Haleh Afshar and Bina Agarwal (eds.) Women, Poverty and Ideology in Asia: Contradictory Pressures, Uneasy Resolutions, The Macmillan Press Limited, pp. 1-17.

Agarwal, Bina, 1988a, 'Patriarchy and the Modernizing State: An Introduction', in Bina Agarwal (ed.) Structures of Patriarchy: State, Community and Household In Modernizing Asia, Leela Dube (series editor) Women and Household in Asia, Vol. 2, Kali for Women, New Delhi, pp.1-28.

----- 1988b, 'Neither Sustenance nor Sustainability: Agricultural Strategies, Ecological Degradation and Indian Women in Poverty', in Bina Agarwal (ed.) Structures of Patriarchy: State, Community and Household in Modernizing Asia, Leela Dube (series editor) Women and Household in Asia, Vol. 2, Kali for Women, New Delhi, pp.83-120.

Anandabazar Patrika (Kolkata), Sep. 16, 2004, "Paricharak dhrita" (Domestic Worker arrested)

Anandabazar Patrika (Kolkata) Jun.19, 2005, "Police rehai dileo churir daye mardhor" (Even after Police release, physical abuse on suspicion of theft)

Anker, Richard, Khan M.E, and Gupta R.B, 1988, Women's Participation in the Labour Force: A Methods Test in India for improving its Measurement, Women, Work and Development 16, International Labour Office, Geneva.

Annual Report, 2004-05, Nishtha

Annual Report, 2004-05, Parichiti

Appadurai, Arjun, 2001a, 'Grassroots Globalization and the Research Imagination', in Arjun Appadurai (ed.) Globalization, Duke University Press, Durham, pp. 1-21.

----- 2001b, 'Deep Democracy: Urban Governmentality and the Horizon of Politics', in Environment and Urbanization, Vol. 13, No.2, pp. 23-43.

Asian Development Outlook 2004: II, Economic Trends and Prospects in Developing Asia: South Asia, Retrieved 22/12/05 from the World Wide Web:

http://www.adb.org/Documents/Books/ADO/2004/ind.asp 
Bagchi, Jasodhara, 1990, 'Women in Calcutta: After Independence', in Sukanto Chowdhury (ed.) Calcutta: The Living City, Vol. II, the Present and the Future, Oxford University Press, pp. 42-49.

Banerjee, Abhijit. Bardhan, Pranab. Basu, Kaushik. Choudhuri, Mrinal Datta. Ghatak, Maitreesh.Guha, Ashok Sanjay. Majumdar, Mukul. Mukherjee, Dilip. Ray, Debraj, 2002, 'Strategy for Economic Reform in west Bengal', in Economic and Political Weekly, Oct.12-18, Vol. XXXVII, No. 41, A Sameeksha Trust Publication, pp. 4203-4219.

Banerjee, Nirmala, 1985, 'Women's work and Discrimination', in Devaki Jain and Nirmala Banerjee (eds.) Tyranny of the Household: Investigative Essays on Women's Work, Shakti Books, pp. 146-191.

1989, 'Working Women in Colonial Bengal: Modernization and Marginalization', in Kumkum Sangari and Sudesh Vaid (eds.), Recasting Women: Essays in Colonial History, Kali for Women, New Delhi, pp. 269- 301.

----- 1991, 'Conclusion', in Nirmala Banerjee (ed.) Indian Women in a changing industrial scenario, Indo-Dutch Studies in Development Alternatives-5, Sage Publications, New Delhi, pp. 299-311.

1995, 'Sexual Division of Labour: Myths and Realities in the Indian Context', in Jasodhara Bagchi (ed.), Indian Women: Myth and Reality, Sangam Books, Hyderabad, pp.73-81.

----- 2002, 'Between the Devil and the Deep Sea: Shrinking options for Women in Contemporary India', in Karin Kapadia (ed.) The Violence of Development: The Politics of Identity, Gender and Social Inequalities in India, Zed Books, London, pp.43-68.

Banerjee, Nirmala and Roy, Poulomi, 2004, 'What does the state do for Indian women?' in Economic and Political Weekly, Vol. XXXIX, No. 44, A Sameeksha Trust Publication, pp. 4831-4837.

Banerjee, Swapna, 2004, Men Women and Domestics: Articulating Middle Class Identity in Colonial Bengal, Oxford University Press, New Delhi.

Bangasser, Claire, 2003, 'Working Women's Forum: A case study of leadership development in India', in Arunachalam, J and Landwehr, B, (eds.) Structuring a movement and spreading it on: History and growth of the Working Women's Forum (India) 1978-2003, IKO - Verlag fur Interkulturelle Kommunication, Frankfurt am Main.

Basu, Amrita, 1992, Two Faces of Protest: Contrasting Modes of Women's Activism in India, University of California Press, Berkeley. 
Basu, Kaushik, 2004, 'The Indian Economy: Up to 1991 and Since', in Kaushik Basu (ed.) India's Emerging Economy: Performance and Prospects in the 1990s and Beyond, The MIT Press, Massachusetts, pp.3-31.

Bauman, Zygmunt, 1998, Work, Consumerism and the New Poor, Open University Press, Buckingham.

Bhan, Gautam, 2001, 'India gender profile', in Report Commission for Sida, Report No.62, Bridge (Development Gender), Institute of Development Studies, University of Sussex.

Bhattacharyya, H, 1999, 'Post Partition Refugees and the Communists: A Comparative study of West Bengal and Tripura', in Ian Talbot and Gurharpal Singh (eds.) Region and Partition: Bengal, Punjab and the Partition of the subcontinent, Oxford University Press, pp. 325-346.

Bhattacharyya, Sudhir, 1985, 'On the issue of underenumeration of Women's work in the Indian Data Collection system', in Devaki Jain and Nirmala Banerjee (eds.) Tyranny of the household: Investigative essays on Women's work, Vikas Publishing House, New Delhi, pp.195-214.

Bhoite, Anuradha, 1987, Women Employees and Rural Employment: Problems of Employed Women in Rural Areas, Gian Publishing House, Delhi.

Borthwick, Meredith, 1984, The Changing Role of Women in Bengal 1849-1905 Princeton University Press, Princeton.

Brass, Paul R, 1994, The politics of India since independence, Cambridge University Press, pp. Xx.

Butler, Judith, 1992, 'Contingent Foundations: Feminism and the question of "Postmodernism", in J. Butler and J. W. Scott (eds.) Feminists Theorize the Political, Routledge, New York, pp. 3-21.

Carr, Marilyn, Chen, Martha and Jhabvala Renana, 1996, 'Lessons Learned', in Marilyn Carr, Martha Chen and Renana Jhabvala (eds.) Speaking Out: Women's Economic Empowerment in South Asia, IT Publications on behalf of Aga Khan Foundation Canada and United Nations Development Fund for Women (UNIFEM), pp. 185-218.

Castells, Manuel and Portes, Alejandro, 1989, 'World Underneath: The Origins, Dynamics and Effects of the Informal Economy', in Alejandro Portes, Manuel Castells and Lauren A. Benton (eds.) The Informal Economy: Studies in Advanced and Less Developed Countries, The John Hopkins University Press, Baltimore and London, pp. 11-37. 
Census of India 1991, Census Data Online, Data table 18, Retrieved 20/09/05 from the World Wide Web:

http://www.censusindia.net/

Chandavarkar, Rajnarayan, 1992, 'Workers' Resistance and Rationalization of Work in Bombay between the Wars', in Douglas Haynes and Gyan Prakash (eds.) Contesting Power: Resistance and Everyday Social Relations in South Asia, University of California Press, Los Angeles, pp. 109-144.

Chatterjee, Partha, 1989, 'The Nationalist Resolution of the Women's Question' in Kumkum Sangari and Sudesh Vaid (eds.), Recasting Women: Essays in Colonial History, Kali for Women, New Delhi, pp. 233-253.

1997, The Present History of West Bengal: Essays in Political Criticism, Oxford University Press, Delhi.

Chatterjee, Sisir, 2004, 'Urbanization of Kolkata: A study on impact of migration', in The Geographical Review of India, Vol. 66, No. 4, The Geographical Society of India, Kolkata, pp. 381-390.

Choudhury, Sukanta, 2002, View from Calcutta, Chronicle Books, An imprint of DC Publishers, New Delhi.

Cotterill, Pamela, 1992, 'Interviewing women: Issues of Friendship, Vulnerability, and Power', in Women studies International Forum, Pergamon, Vol.15, Nos. 5/6. pp. 593606.

Dasgupta, Kalpana, 2003, 'Globalization and the Indian Women: Problems, Possibilities and Informational needs- An Overview', in World Library and Information Congress: 69th IFLA General Conference and Council, Science Journal Section.

Deccan Herald (Bangalore) Jun. 12, 2004, "Minimum Wages for Domestic Workers", Retrieved 05/01/06 from the World Wide Web:

http://www.deccanherald.com/deccanherald/jun122004/s9.asp

Deccan Herald (Bangalore) Jul. 06, 2004, Subramani, L., "An empowered Union". Retrieved 05/01/06 from World Wide Web:

http://www.deccanherald.com/deccanherald/july062004/spt3.asp

Desai, Neera and Krishnaraj, Maithreyi, 1990, Women and Society in India, Ajanta Publications, India.

Devi, U Lalitha, 1982, Status and Employment of Women in India, B.R. Publishing, Delhi. 
Dewan, Ritu, 1999, 'Gender Implications of the "New" Economic Policy: A Conceptual Overview', in Women's Studies International Forum, Vol. 22, No. 4, pp. 425-429.

Dreze, Jean and Sen, Amartya, 2002, India: Development and Participation, Second Edition, Oxford University Press.

Dumont, Louis, 1980, Homo Hierarchicus: The caste system and its implications, Mark Sainsbury, Louis Dumont and Basia Gulati (trans.), The University of Chicago Press, Chicago and London.

Duncombe, Jean and Jessop, Julie, 2002, 'Doing rapport and the ethics of faking frienship', in M. Mauthner, M. Birch, J. Jessop and T. Miller (eds.) Ethics in Qualitative Research, Sage Publications, London, pp. 107-122.

Dutta, Dilip, 2002, Effects of Globalization on Employment and Poverty in Dualistic Economies: The case of India, University of Sydney.

Dwyer, Claire and Limb, Melanie, 2001, 'Introduction: Doing qualitative research in Geography', in M. Limb and C. Dwyer (eds.) Qualitative Methodologies for Geographers: Issues and Debates, Arnold and Oxford University Press, London and New York, pp. 1-20.

Dyson, Tim and Visaria, Pravin, 2004, 'Migration and Urbanization: Retrospect and Prospects', in Tim Dyson, Robert Cassen and Leela Visaria (eds.) Twenty First Century India: Population, Economy, Human Development and the Environment, Oxford University Press, pp. 108-129.

Edwards, Rosalind and Mauthner, Melanie, 2002, 'Ethics and Feminist Research: Theory and Practice', in M. Mauthner, M. Birch, J. Jessop and T. Miller (eds.) Ethics in Qualitative Research, Sage Publications, London, pp. 14-31.

Elson, Diane, 1995, 'Male bias in the development process: An overview', in Diane Elson (ed.) Male Bias in the Development Process, Manchester University Press, Manchester, pp. 1-28.

Escobar, Arturo, 1995, Encountering Development: The Making and Unmaking of the Third World, Princeton University Press, New Jersey.

Everett, J. M, 1979, Women and social change in India, Heritage publishers, New Delhi.

Fals Borda, Orlando and Rahman, Muhammad Anisur, 1991, 'Introduction', in Orlando Fals Borda and Muhammad Anisur Rahman (eds.) Action and Knowledge: Breaking the Monopoly with Participatory Action-Research, Apex Press, Intermediate Technology Publications, New York, pp. 3-36. 
Flax, Jane, 1990, Thinking Fragments: Psychoanalysis, Feminism, and Postmodernism in Contemporary West, University of California Press, Berkeley.

Fraser, Nancy and Nicholson, Linda, 1990, 'Social criticism without Philosophy: An encounter between Feminism and Postmodernism', in Linda Nicholson (ed.) Feminism/Postmodernism, Routledge, New York and London, pp. 19-38.

Fruzzetti, Lina M., 1982, The Gift of a Virgin: Women Marriage and Ritual in a Bengali Society, Rutgers University Press, New Brunswick, New Jersey.

Gandhi, Anuradha and Chaudhury, Nagesh, 1984, 'Towards a day when there will be no servants: Domestic Servants of Nagpur Organize', in Madhu Kishwar and Ruth Vanita (eds.) In Search of Answers: Indian Women's voices from Manushi, Zed Books, London, pp. 115-119.

Ganguly Scrase, Ruchira, 2003, 'Paradoxes of Globalization, Liberalization and Gender Equality- The world-views of the Lower Middle Class in West Bengal, India', in Gender and Society, Vol. 17, No.4, pp.544-566.

Ghose, Ajit K, 2004, 'The Employment Challenge in India', in Economic and Political Weekly, A Sameeksha Trust Publication, Vol. XXXIX, No. 48, Oct-Nov, pp. 5106-5116.

Global Fund for Women, 2005, Retrieved 14/11/05 from the World Wide Web: http://www.globalfundforwomen.org/

Global Giving, 2004, Retrieved 20/11/05 from the World Wide Web: http://www.globalgiving.com/pr/700/proj683p.html

Gopalan, Sarala, 1995, Women and Employment in India, Har Anand Publications.

Goswami, Omkar, 1990, 'Calcutta's Economy 1918-1970: The Fall from Grace', in Sukanto Chowdhury (ed.) Calcutta: The living city, Vol. II, The Present and the Future, Oxford University Press, pp. 88-96.

Government of India, 1988, Shramshakti: National Commission on Self Employed Women and Women in the Informal Sector, New Delhi.

Government of West Bengal, 2004, West Bengal Human Development Report, Development and Planning Department.

Gupta, Jayoti, 2002, 'Women Second in the Land Agenda', in Economic and Political Weekly, Vol. XXXVII, No. 18, A Sameeksha Trust Publication, pp. 1746-1754.

Guruswamy, Mohan. Sharma, Kamal and Mohanty, Jeevan. Prakash, 2005, 'Economic Growth and Development in West Bengal: Reality versus Perception', in Economic and Political Weekly, A Sameeksha Trust Publication, Vol. XL, No. 21, pp. 2151-2157. 
Haraway, Donna J, 1991, Simians, Cyborgs and Women: The Reinvention of Nature, Free Association Books, London.

Harding, Sandra, 1992, 'Subjectivity, Experience and Knowledge: An Epistemology from/for Rainbow Coalition Politics', in Development and Change, Sage Publications, London, Vol. 23, pp.175-193.

Hariss-White, Barbara, 2004, 'India's Informal Economy: Facing the Twenty First Century', in Kaushik Basu (ed.) India's Emerging Economy: Performance and Prospects in the 1990s and Beyond, The MIT Press, Massachusetts, pp. 265-291.

Haynes, Douglas and Prakash, Gyan, 1992, 'Introduction: The Entanglement of Power and Resistance', in Douglas Haynes and Gyan Prakash (eds.) Contesting Power: Resistance and Everyday Social Relations in South Asia, University of California Press, Los Angeles, pp. 1-22.

Hensman, Rohini, 1999, 'Impact of Technological Change on Industrial Women Workers' in Nivedita Menon (ed.) Gender and Politics in India, Oxford University Press, pp. 178-193.

Heyzer, Noeleen, 1994, 'Introduction: Market, State and Gender Equity', in Noeleen Heyzer and Gita Sen (eds.) Gender, Economic Growth and Poverty: Market Growth and State Planning in Asia and the Pacific, Kali for Women, New Delhi, International Books, Netherland and Asia and Pacific Development Center, Malaysia, pp. 3-27.

Hoggart, K, Lees, L and Davies, A, 2002, Researching Human Geography, Arnold and Oxford University Press, London and New York.

IndianNGOs.com, Retrieved 10/01/06 from the World Wide Web: http://www.indianngos.com/interviews/jeannedevos.htm

India Together (Bangalore) Nov, 2004, Barat, T., "The Dark Side of Indian Homes", Retrieved 07/01/06 from the World Wide Web:

http://www.indiatogether.org/2004/nov/hrt-domhelp.htm

India Together (Bangalore) Apr, 2004, Dhavse, R., "Organizing inside the home", Retrieved 08/01/06 from the World Wide Web:

http://indiatogether.com/2004/apr/eco-domestic.htm

International Labour Organization, 1991, The Dilemma of The Informal Sector, Report of the Director-General, International Labour Conference, 78th Session, Geneva

International Labour Organization, 2002, Decent Work and the Informal Economy, Report IV, International Labour Conference, 90th Session, Geneva 
Jhabvala, Renana and Sinha, Shalini, 2002, 'Liberalization and the Woman Worker', in Economic and Political Weekly, A Sameeksha Trust Publication, Vol. XXXVII, No. 21, pp.2037-2044.

Jhappan, Radha, 1996, 'Post-modern race and gender essentialism or a post-mortem of scholarship', in Studies in Political Economy, No. 51, pp. 15-63.

Jose, Sunny, 2003, 'Gender Bias in Resource allocation in India: Where do Household Models and Empirical Evidence intersect', in Indian Journal of Gender Studies, Vol. 10, No.3, Sage Publications, New Delhi, Sep.-Dec., pp. 405-430.

Kalpagam, U, 1994, Labour and gender: Survival in Urban India, Sage Publications, New Delhi.

2002, 'Perspectives For a Grassroots Feminist Theory', in Economic and Political Weekly, Nov 23-29, Vol. XXXVII, No. 47, A Sameeksha Trust Publication, pp. 46864693.

Kasturi, Leela, 1990, 'Poverty and Women's status', in Vina mazumdar (ed.) Women Workers in India: Studies in Employment and Status, Chanakya Publications, Delhi, pp. 3-172.

Kishor, Sunita and Gupta, Kamla, 2004, 'Women's Empowerment in India and its States: Evidence from NFHS', in Economic and Political Weekly, A Sameeksha Trust Publication, Vol. XXXIX, No. 7, pp. 694-712.

Kishwar, Madhu, 1993, 'Dowry Calculations: Daughter's Rights in her Parental Family', in Manushi, Sep.-Oct., No. 78, pp. 8-17.

------- 1996, 'A Half Step Forward: The Thwarting of Economic Reforms in India', in Manushi, January-April, No. 92-93, pp. 51-80.

Kobayashi, Audrey, 2001, 'Negotiating the personal and the political in critical qualitative research', in M. Limb and C. Dwyer (eds.) Qualitative Methodologies for Geographers: Issues and Debates, Arnold and Oxford University Press, London and New York, pp. 55-70.

Kodoth, Praveena,2005, 'Fostering Insecure Livelihoods: Dowry and Female Seclusion in Left Developmental Contexts in West Bengal and Kerala', in Economic and Political Weekly, A Saameeksha Trust publication, Vol. XL, No. 25, pp. 2543-2554.

Krishnamurty, K, 2000, 'Economic Liberalization and Planning in India: Prospectives and Modelling', in R.V.R. Chandrasekhara Rao, A. Prasanna Kumar and K.C. Reddy (eds.) Perspectives on Indian Development: Economy, Polity and Society (Essays in Honour of Prof. B. Sarveswara Rao), Sterling Publishers, pp. 3-20. 
Krishnaraj, Maitreyi, 1995, 'Motherhood: Power and Powerlessness', in Jasodhara Bagchi (ed.) Indian Women: Myth and Reality, Sangam Books, Hyderabad, pp.34-43.

Kulkarni, Veena, 1996, 'Why they Drop Out: Reasons for the Lower Literacy among Girls', in Manushi, Nov-Dec, pp. 32-38.

Lessinger, Johanna, 1990, 'Work and Modesty: The Dilemma of Women market Traders in Madras', in Leela Dube and Rajni Palriwala (eds.) Structures and Strategies: Women, Work and Family, Sage Publication, New Delhi, pp. 129-149.

Madan, T N, 1985, 'Concerning the categories of Subha and Suddha in Hindu Culture: An Exploratory Essay', in John B. Carman and Frederique Apffel Marglin (eds.) Purity and Auspiciousness in Indian Society, Leiden, E.J. Brill, pp. 11-29.

Marchand, Marrianne H. and Runyon, Anne S, 2000, 'Introduction- Feminist Sightings of Global Restructuring: Conceptualizations and Reconceptualizations', in Marianne H. Marchand and Anne S. Runyon (eds.) Gender and Global Restructurings- Sightings, Sites and Resistances, Routledge, pp. 1-22.

Mbilinyi, Marjorie, 1992, 'Research Methodologies in Gender Issues', in Ruth Meena (ed.) Gender in Southern Africa: Conceptual and Theoretical Issues, Sapes Book, Harare, pp. 31-70.

Mehta, Asha Kapur, 2000, 'The Invisible Workers: Women's Unrecognized Contribution to the Economy', in Manushi, No. 121, Nov-Dec, pp. 27-31.

Mishra, Bikram Keshari, 2004, 'Changing Meaning of Work: A Gendered Perspective', in Labour and Development, Vol. 10, No. 1, pp. 126-155.

Mitter, Sara S, 1991, Dharma's Daughters: Contemporary Indian Women and Hindu Culture, Penguin Books.

Moghadam, Valentine, 1999, 'Gender and Globalization: Female labour and Women's Mobilization', in Journal of World-Systems Research, Vol. V.2, pp. 367-388.

Mohanty, Chandra Talpade, 1991, 'Introduction- Cartographies of Struggle: Third World Women and the Politics of Feminism', in Chandra Talpade Mohanty, Ann Russo and Lourdes Torres (eds.) Third World Women and the Politics of Feminism, Indiana University Press, Bloomington, pp. 1-47.

---- 2003, Feminism without Borders: Decolonizing Theory, Practicing Solidarity, Duke University Press, Durham and London.

Mohanty, S and Ram, U, 2004, Occupational Pattern of Labour Force in the Metropolitan Cities of India: An Assessment from NFHS-2, IIPS (International Institute of Population Studies) Newsletter, Mumbai. 
Mukherjee, Mukul, 2004, 'Women and Work in the Shadow of Globalization', in Indian Journal of Gender Studies, Vol. 11, No. 3, Sage Publications, New Delhi, pp. 275-290.

Murshid, Ghulam, 1983, Reluctant Debutante: Response of Bengali Women to Modernization 1849-1905, Rajshahi University Press, Rajshahi.

Narasimhan, Sakuntala, 2000, 'Reflections on Indian Economic Development and Poverty Eradication- Developments as if People Mattered', in R.V.R. Chandrasekhara Rao, A. Prasanna Kumar and K.C. Reddy (eds.) Perspectives on Indian Development: Economy, Polity and Society (Essays in honour of Prof. B. Sarveswara Rao), Sterling Publishers, New Delhi, pp. 214-234.

Narayan, Uma, 1997, Dislocating Cultures: Identities, Traditions, and Third World Feminism, Routledge, New York.

Neetha, N, 2003, 'Migration for Domestic work: Women Domestics in Delhi', in Labour and Development, Vol. 9, No. 7, pp. 118-135.

Oldenburg, Veena Talwar, 1992, 'Lifestyles as Resistance: The Case of the Courtesans of Lucknow', in Douglas Haynes and Gyan Prakash (eds.) Contesting Power: Resistance and Everyday Social Relations in South Asia, University of California Press, Los Angeles, pp.23-61.

Palriwala, Rajni, 1990, 'Introduction', in Leela Dube and Rajni Palriwala (eds.), Structures and Strategies: Women, Work and Family, Sage Publication, New Delhi, pp.15-55.

Parpart, Jane L, 1993, 'Who is the 'Other'? : A Postmodern Feminist critique of Women and Development Theory and Practice', in Development and Change, Sage Publications, London, Vol. 24, pp. 439-464.

Parpart, Jane L and Marchand, Marianne H, 1995, 'Exploding the canon: An Introduction/Conclusion', in Marianne H. Marchand and Jane L. Parpart (eds.) Feminism/Postmodernism/Development, Routledge, London, pp. 1-22.

Pore, Kumud, 1991, 'Women at Work- A Secondary line of Operation: A study of the socio-economic condition of women workers in the garment industry and the electronic industry in Thane and Pune, Maharashtra', in Nirmala Banerjee (ed.) Indian Women in a changing industrial scenario, Indo- Dutch Studies in Development Alternatives-5, Sage Publications, New Delhi, pp. 201-236.

Raghuram, Parvati and Momsen, Janet, 1993, 'Domestic service as a survival strategy in Delhi, India,' in Geoforum, Volume 24, Number 1, pp. 55-62. 
Raghuram, Parvati, 2001, 'Caste and Gender in the organization of paid domestic work in India', in Work, Employment and Society, Vol. 15, No.3, pp. 607-617.

Raju, Saraswati, 1993, 'Introduction', in Sarawati Raju and Deipica Bagchi (eds.) Women and Work in South Asia: Regional Patterns and Perspectives, Routledge, London and New York, pp.1-38.

----- 2002, 'We are different, but can we talk?', in Gender, Place and Culture, Carfax Publishing, Vol. 9, No. 2, pp. 173-177.

Ramu, G. N, 1989, Women, Work and Marriage in Urban India: A Study of Dual and Single earner couples in India, Sage Publications, New Delhi.

Rani, Uma and Unni, Jeemol, 2004, 'Women, Work and Insecurities in India,' in Labour and Development, Vol. 10, No. 2, V. V. Giri National Labour Institute, Noida, pp.104136.

Rath, Navaneetha, 1996, Women in Rural Society: A Quest for Development, M.D. Publications, New Delhi.

Ray, Bharati, 2002, 'Globalization, quality of Life and Women in India', in Donald Lamberton (ed.) Managing the Global: Globalization, Employment and Quality of Life, I. B. Tauris Publishers, London, in association with the Toda Institute of Global Peace and Policy Research, pp. 145-162

Ray, Raka, 1999, Fields of Protest: Women's Movements in India, University of Minnesota Press.

----- 2000, 'Masculinity, Feminity and Servitude: Domestic workers in Calcutta in the late twentieth century', in Feminist Studies 26, No. 3, pp. 691-718.

Robb, Peter, 2002, A History of India, Palgrave Publishers, Hampshire

Romp, Graham, 1997, Game Theory: Introduction and Applications, Oxford University Press, Oxford.

Rose, Gillian, 1997, 'Situating Knowledges: Positionality, Reflexivities and other Tactics', in Progress in Human Geography 21, No.3, pp. 305-320.

Roy, Ananya, 2003, City Requiem, Calcutta: Gender and Politics of Poverty, University of Minnesota Press, Minneapolis.

RoyChowdhury, Supriya, 2004, 'Globalization and Labour', in Economic and Political Weekly, A Sameeksha Trust Publication, Vol. XXXIX, No.1, pp. 105-108. 
Sadasivam, Bharati, 1997, 'The Impact of Structural Adjustment on Women: A Governance and Human Rights Agenda', in Human Rights Quarterly 19.3, The John Hopkins University Press, pp.630-635.

Saiyed, A. R, 1992, 'Muslim Women in India: An Overview', in Mohini Anjum (ed.) Muslim Women in India, Radiant Publishers, New Delhi, pp. 1-8.

Samuel, John, 2001, 'India: Withering of the Welfare State', in Social Watch, Gnana Prakasam, pp. 114-115.

Saradamoni, K., 1992, 'Women, Production and Work' in K. Saradamoni (ed.) Finding the Household: Conceptual and Methodological Issues, Leela Dube (series editor) Women and the Household in Asia, Vol. 5, Sage Publications, New Delhi, pp. 163-180.

Savara, Mira, 1986, Changing Trends in Women's Employment: A Case Study of the Textile Industry in Bombay, Himalaya Publishing House, Bombay.

Scott, James, 1985, Weapons of the Weak: Everyday forms of Peasant Resistance, Yale University Press, London.

Sen, Amartya, 1992, Inequality Reexamined, Harvard University Press, New York.

----- 2005, The Argumentative Indian: Writings on Indian History, Culture and Identity, Allen Lane an imprint of Penguin Books.

Sen, Gita and Batliwala, Srilatha, 2000, 'Empowering Women for Reproductive Rights', in Harriet B. Presser and Gita Sen (eds.) Women's Empowerment and Demographic Processes: Moving Beyond Cairo, Oxford University Press, pp.15-36.

Sen, Samita, 2002, 'Towards a Feminist Politics? The Indian Women's Movement in Historical Perspective', in Karin Kapadia (ed.) The Violence of Development: The Politics of Identity, Gender and Social Inequalities in India, Zed Books, London, pp. 459-524.

Sen, Siddhartha, 1999, 'Some aspects of state-NGO relationships in India in the postindependence era', in Development and Change, Vol. 30, Blackwell Publishers, Oxford, pp. 327-355.

Sharma, Alakh N, 2004a, Globalization, labour markets and poverty: Towards an agenda for decent work in India, Paper prepared for the 1st Global Labour Forum to be held during the 5th Asian Regional Congress of the International Industrial Relations Association, Institute for Human development, Indian Society of Labour Economics, New Delhi.

Sharma, Savita, 2004b, 'Poverty Estimates in India- Some Key Issues', in ERD Working Paper Series, Asian Development Bank. 
Sinclair, M. Thea, 1991, 'Women, Work and Skill: Economic Theories and Feminist Perspectives' Nanneke Redclift and M. Thea Sinclair (eds.) Working Women: International Perspectives on Labour and Gender Ideology, Routledge, London, pp. 124.

Sisson, Richard and Rose, Leo, 1990, War and Secession: Pakistan, India and the Creation of Bangladesh, University of California Press, Berkeley.

Spivak, Gayatri Chakraborty, 1988, 'Can the Subaltern Speak?' in Cary Nelson and Lawrence Grossberg (eds.) Marxism and the interpretation of culture, University of Illinois Press, Urbana, pp.271-313.

Srinivas, M.N, 2003, 'An Obituary of Caste as a System', in Economic and Political Weekly, A Sameeksha Trust Publication, Vol. XXXVIII, No. 5, Feb. 1-7, pp.455-459.

Sundar, Ramamani, 2001, 'Typecast Early: How Teenagers see Gender Roles' in Manushi, Nov-Dec, No. 127, pp. 18-21.

Swaminathan, Padmini, 2002, 'The Violence of Gender-Biased Development: Going Beyond Social and Demographic Indicators' in Karin Kapadia (ed.) The Violence of Development: The Politics of Identity, Gender and Social Inequalities in India, Zed Books, London, pp. 69-141.

2004, 'The Trauma of Wage Employment and the Burden of Work for Women in India: Evidences and Experiences', in Labour and Development, Vol. 10, No. 2, V. V. Giri National Labour Institute, Noida, pp. 63-103.

The Hindu (Bangalore) Apr. 7, 2003, Maheshwari, R., "Caught in a vicious circle", Retrieved 05/01/06 from the World Wide Web: http://www.hinduonnet.com/thehindu/mp/2003/04/07/stories/2003040701130100.htm

The Hindu (Bangalore) May 31, 2004, Nagarajan, S., "Finding their voice", Retrieved 05/01/06 from the World Wide Web:

www.hinduonnet.com/thehindu/mp/2004/05/31/stories/2004053101130200.htm

The Statesman (Kolkata) May 5, 2005, "Help batters housewife"

United Nations, 1991, The World's Women 1970-1990: Trends and Statistics, Social Justice and Indicators, Series K, No. 8, New York.

United Nations, 1993, Department of Economics and Social Affairs, Statistics Division About the System of National Accounts 1993, Retrieved 03/12/05 from the World Wide Web:

http://unstats.un.org/unsd/snal993/introduction.asp 
United Nations, 1995, The World's Women: Trends and Statistics, Social Statistics and Indicators, Series K, No. 12, New York.

United Nations, 2003, ESCAP, Statistics Division, Documentation for the workshop/ Country Papers: India, Retrieved 29/11/05 from the World Wide Web:

http://www.worldenable.net/escapstats/paperindia.htm

Verma, V. S, 1988, 'Foreword', in Census of India 1981, Series I, Part XII, Census Atlas, National Volume.

Villarreal, Magdalena, 1992, 'The Poverty of Practice: Power, gender and intervention from an actor-oriented perspective', in Norman Long and Ann Long (eds.) Battlefields of Knowledge: The Interlocking of theory and practice in social research and development, Routledge, London, pp. 247-267.

Visaria, Pravin and Visaria, Leela, 1985, 'Indian Households with Female Heads: Their Incidence, Characteristics and level of Living', in Devaki Jain and Nirmala Banerjee (eds.) Tyranny of the Household: Investigative Essays on Women's Work, Vikas Publishing House, pp. 50-83.

Walby, Sylvia, 1990, Theorizing Patriarchy, Basil Blackwell, Oxford.

Waring, Marilyn, 1988, If Women Counted, Harper Collins, New York. 